Historic, Archive Document

Do not assume content reflects current scientific knowledge, policies, or practices. 



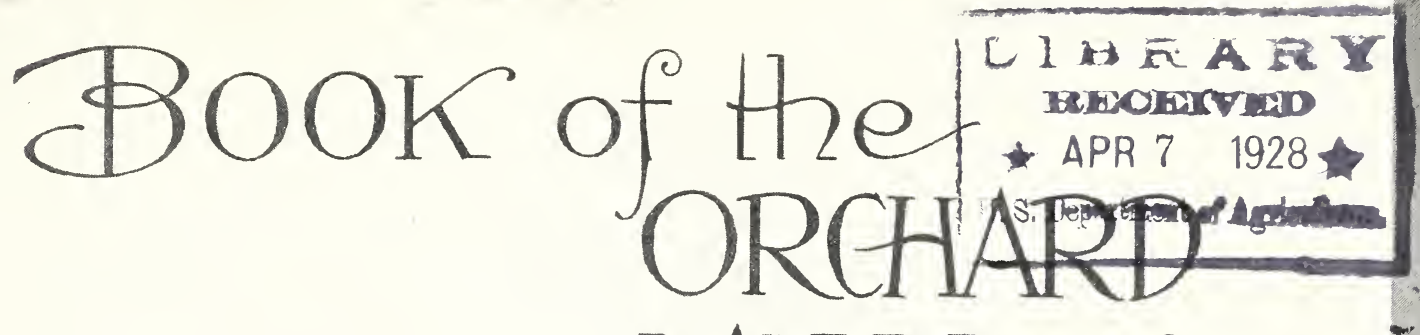

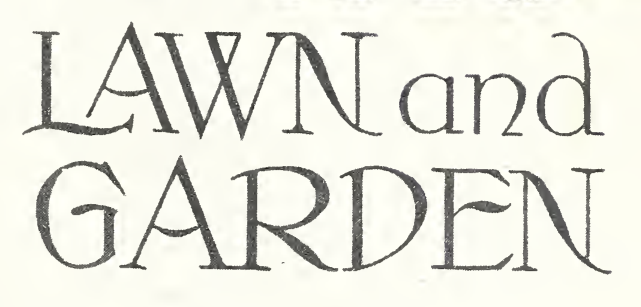

A poet here might find a theme, An artist see a color dream, Or fiction take a flight.

7.

byth

1.

ron

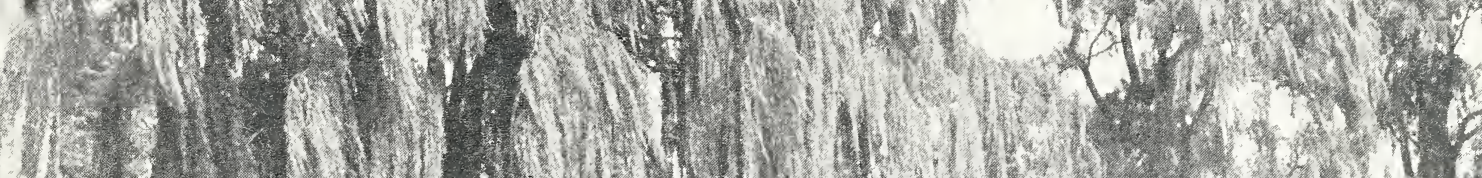

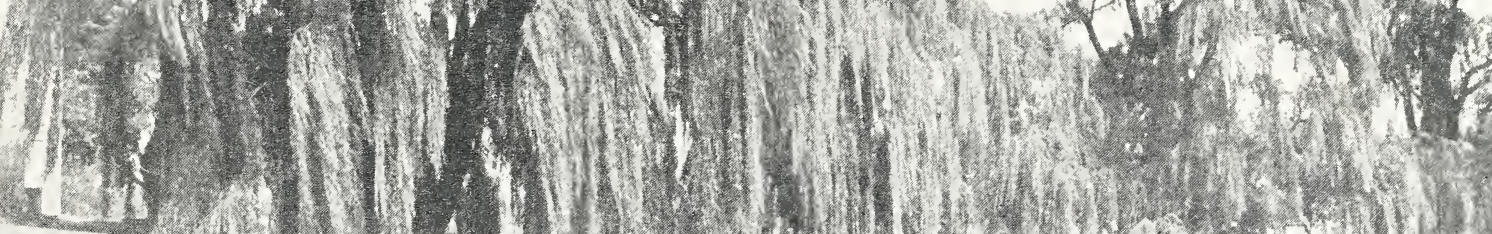




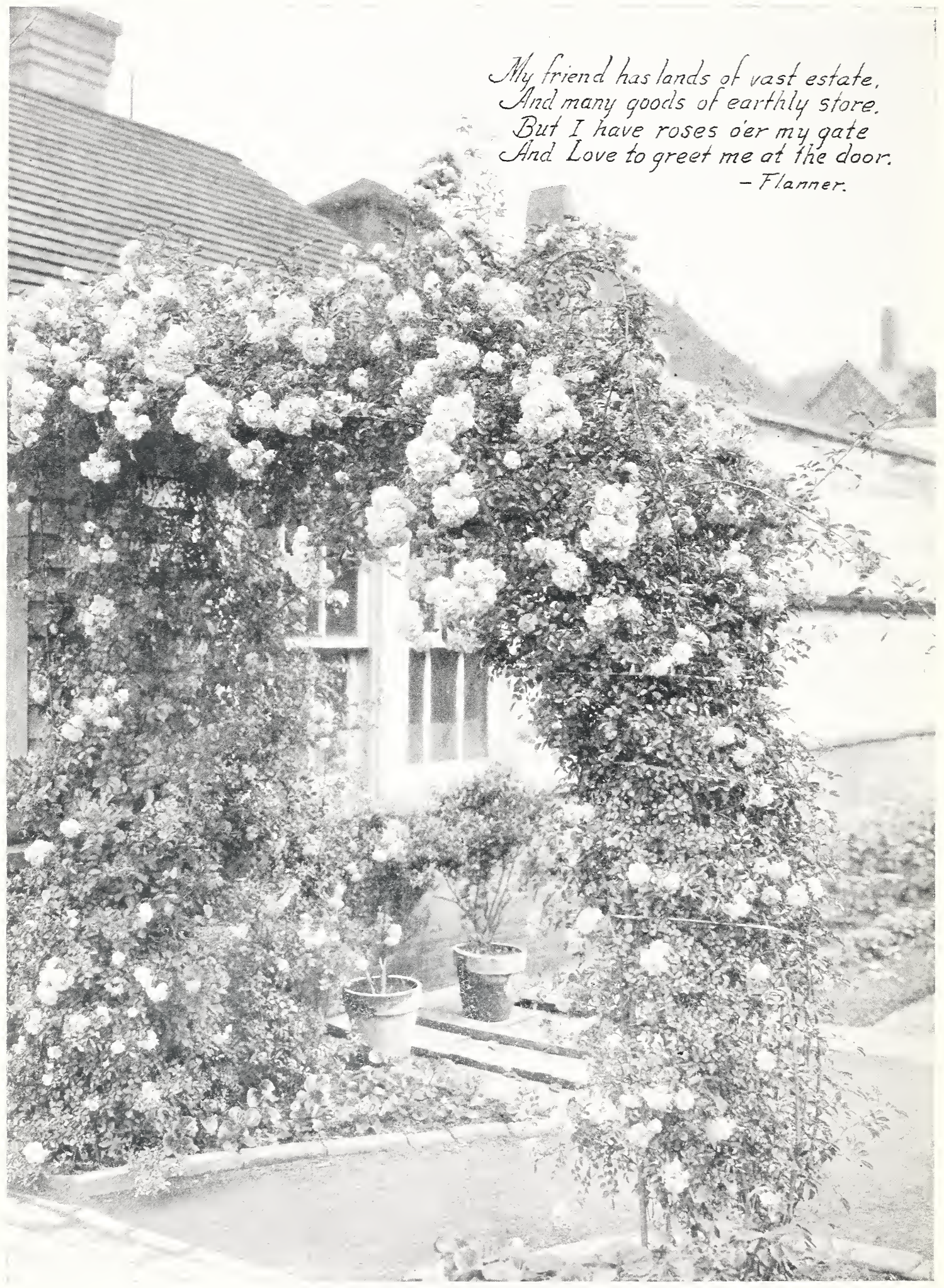




\section{Fruit Department}

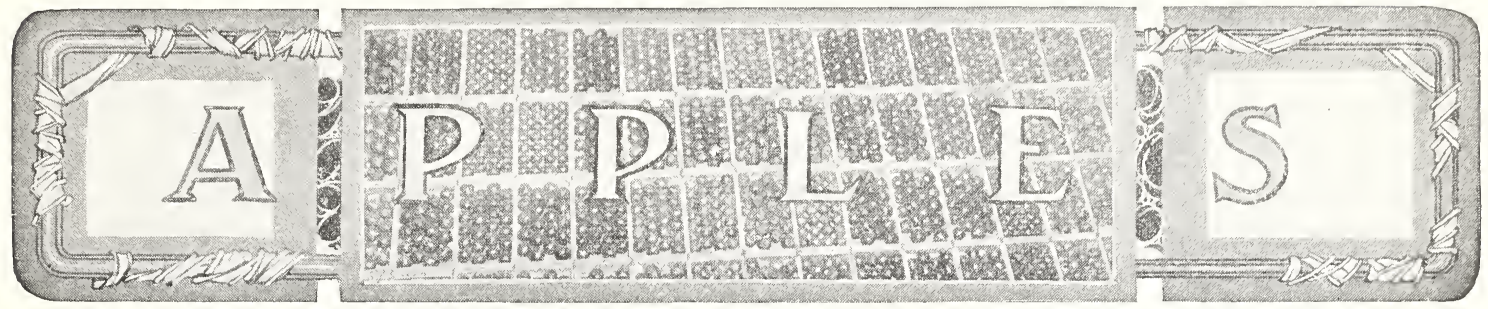

$\mathrm{T}$

HE apple is the first in importance of all fruits. It will thrive on nearly any well drained soil. Its period of ripening, unlike other truits, extends nearly through the whole season. By making careful selection, a constant succession can be obtained. For family use there is no fruit that is more indispensable. No fruit is so healthful and many physicians say that if a person would eat an apple a day they could dispense with doctor bills. Besides this, and just as important, is the fact that the average price on the market is steadily increasing and the immense demand for home consumption, foreign shipping, canning and evaporating assures high prices. The apple if given the same care and attention as other farm crops, will yield greater returns per acre. The following list we consider to be the best for general planting.

\section{Early Summer Varieties}

DUCHESS · OF OLDENBURG-Season, July and August. Tree upright, vigorous and extremely hardy. An early and annual bearer of uniformly large crops. Fruit large, greenish yellow, with red stripes. Flesh light yellow, mediun fine grain, firm; flavor a pleasant acid; a great cooking and fine market sort.

EARLY HARVEST-Size, medium, roundish, usually more or less oblate, smooth, bright straw color when ripe; flesh nearly white, flavor rather acid, fine. Season July. Productive. Needs rich cultivation to be fine. Good thronghout the Northern states and Sonthwest.

GOLDEN SWEET-Medium or rather large, roundish, slightly flattened; greenish, becoming pale yellow; flesh very sweet, good, of moderate quality. The fruit is always fair, the tree is a free grower and very productive. Late summer. Tender for West; succeeds well in Southwest.

RED ASTRACHAN-Season, July. Tree upright spreading, vigorous growth; an early and abundant bearer. Fruit above medium, greenish-yellow, almost covered with mottled and striped crim. son; flesh white; erisp, juicy, brisk acid; good.

RED JUNE-Size medium, oblong, with brilliant red skin; flesh white, tender, jnicy, sub-acid, with a sprightly agreeable flavor; quite early and continues to ripen for four weeks, and will keep long after ripe for a summer apple; profitable for market. The tree is fine erect grower, very hardy, bears young and abundantly. A valuable early apple.

YELLOW TRANSPARENT-Season, July. One of the most valuable early apples. Fruit medium, smooth, transparent skin; clear white, becoming pale yellow when fully ripe; flesh white, tender, fine grained, of splendid quality. Treo is moderately vigorous and a good annual bearer. One of the few sorts that do well even on poor thin land.

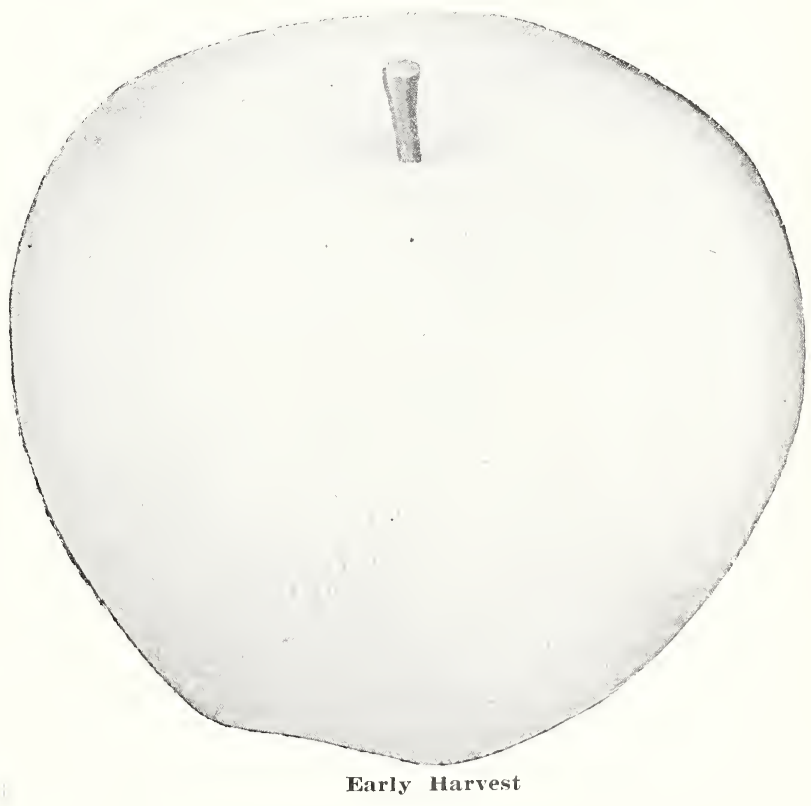




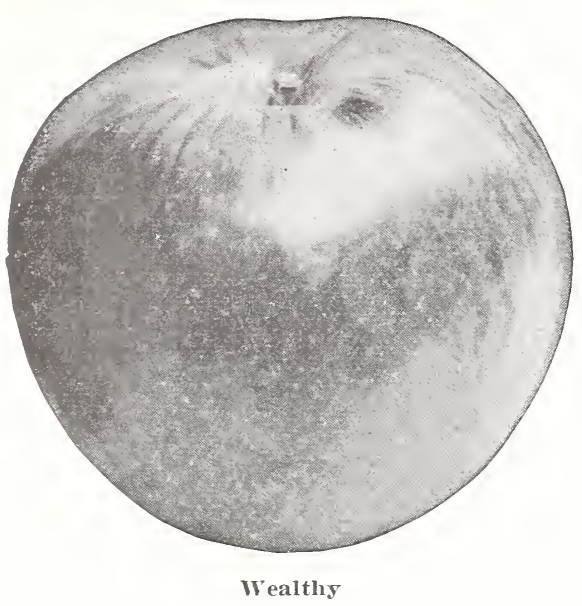

\section{Mid-Summer and Fall Varieties}

CHENANGO STRAWBERRY - Rather large, oblong-conic, angular; striped and splashed with light crimson on whitish yellow-ground; cavity narrow and deep; basin narrow; flesh white, very tender, with a pleasant, mild, sub-acid flavor. September.

FAMEUSE (Snow Apple)-Season, October and November. An old and well known variety. Tree a moderate grower. Very hardy and not very well adapted for growing in the South. Productive. Fruit medium in size; color pale greenish-yellow, mixed with stripes of red with splashes of same on shady side; flesh white, tender and juicy, slightly perfumed; flavor sub-acid, extra good.

MAIDEN BLUSH-Of uniformly good size, smooth, round, beautifully flushed with red on ereamy yellow ground; flesh tender, of pleasant but not high flavor. A good market sort because of its attractiveness. Tree is a heavy cropper. September.

RAMBO-Size medium, oblate, smooth. Greenish-yellow, streaked and marbled with dull red dots. Flesh tender, rish. mild suh-acid, fine flavored, often excellent. Late autumn and early winter.

WEALTHY - Is now extensively planter in all the apple-growing states and may be termed the best apple of its season. Fruit large, regular smooth, light yellow with crimson stripes and splashes; flesh white, often stained with red, tender, very juicy, sprightly subacid with delicious aro-

ma. Splendid dessert and cooking apple. Fine for home garden as well as commercial orchards. Season, September to January.

\section{Winter Varieties}

ARKANSAS BLACK-A remarkably handsome, large perfectly smooth apple. Roundish flat to conical shapes; color a very dark red, slightly dotted with white. Flesh is yellow, juicy and delicious, keeping late. December to April.

BALDWIN-Season, December to March. The great commercial late winter keeper of the Eastern states. Tree a vigorous open grower, upright in tendency and very productive where hardy. Comes slow into bearing, but produces abundantly when mature. Fruit large, rounded, deep red; flesh rich, crisp and juicy.

BELLFLOWER-(Yellow Bellefleur)-Large, often quite large; surface pale yellow, often with a blush; very tender when ripe, fine grained, crisp, juicy, acid, becoming sub-acid, excellent, keeps all through winter. Growth of tree rather upright; succeeds best on rather light soils where it bears exceptionally fine crops.

BEN DAVIS-Season, January to April. Vies with Baldwin as a profitable commercial variety in many sections; quality not so good, but a better bearer and keeper. Tree very vigorous and hardy in the Central States. Fruit large, handsome, brightly striped with red; flesh medium quality.

DELICIOUS-This variety is one of the most popular if not the most popular dessert or eating apple on the market. It is fully as good as its name implies-it is truly "Delicious." It is medium to large, oblong and of the sheepnose type. Color light green, shaded, splashed and mottled with light and dark erimson. It is fine grained, juicy, mild. Is fully as hardy as Winesap and should be given a place in every home orchard.

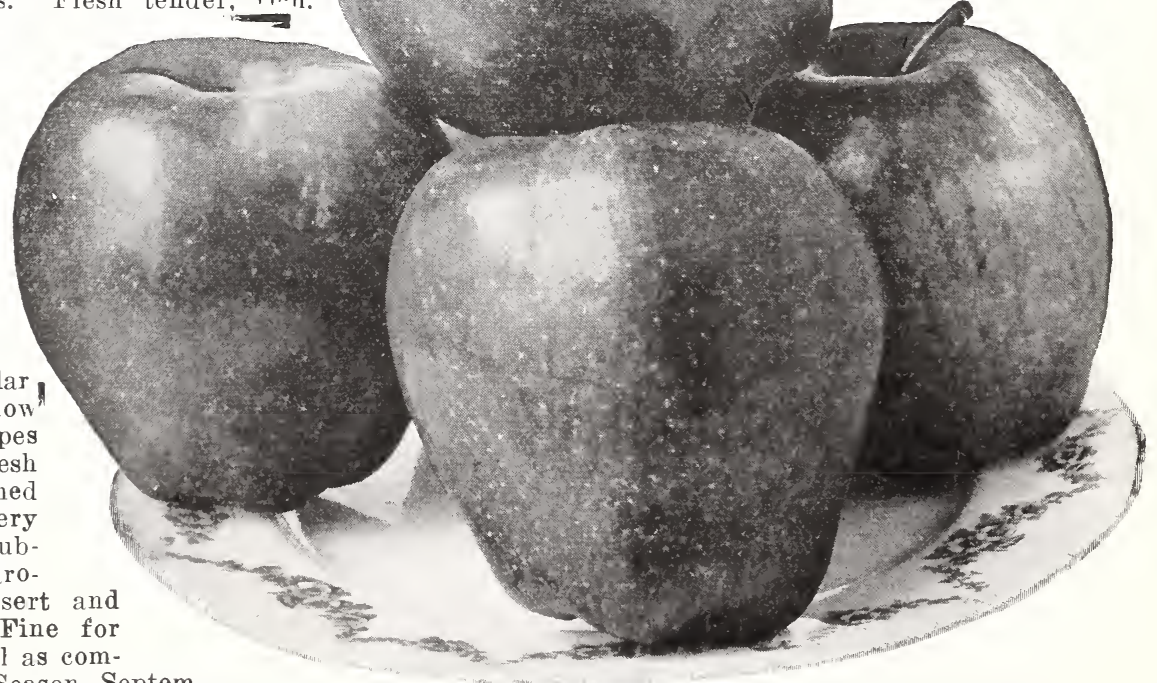

Delicious 
GANO-This variety is supposed to be a cross between Ben Davis and Jonathan. It resembles Ben Davis very closely both in tree and fruit except the color in which the red is evenly overspread and shows no inclination to be striped. In hardiness, keeping qualities and season it is very similar to Ben Davis. This variety is preferred by some commercial growers on account of its better color.

GRIMES' GOLDEN-An apple of the highest quality. It is one of the fancy dessert apples and ranks with Delicious and Jonathan on the markets. Medium to large; bright yellow with pink cheek; flesh fine grained, juicy, with a very pleasing spicy flavor. Like Jonathan it is equally adapted to almost all culinary uses as well as for eating out of the hand. For pies, marmalade, sauce and dumplings, it is one of the best. It has hardly enough acid for the best jelly apple. The tree is hardy, grows upright and is quite disease and insect resistant. Season of fruit, November to January.

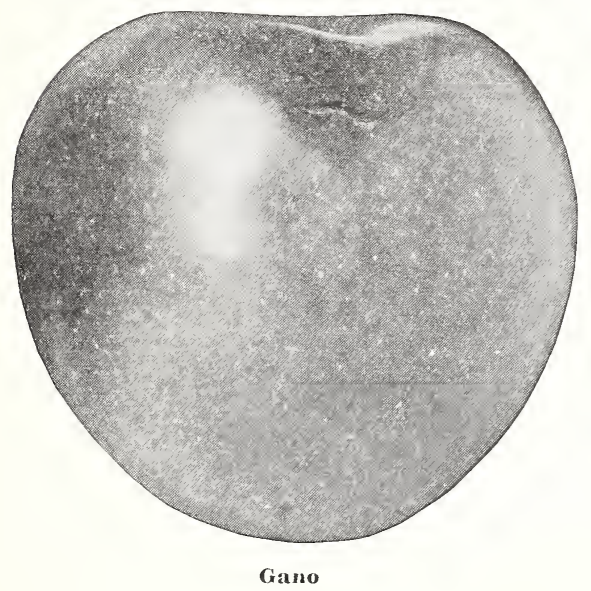

JONATHAN-This variety is probably better known to average consumers of dessert apples than any other va. riety, It is recognized on all markets of the country as one of the best among the few leaders of high qual. ity eating apples. The fact that its qualities and flavor are also superior and outstanding when used for culinary purposes adds to its popularity. The fruit is medium size, red and beautiful. The tree is slightly slow of growth when young, but grows stronger as it attains age. It bears young and abundantly. It is quite hardy and thrives in all of the Central West except in the drier portions of the northwest part. Season November to February.

HUNTSMAN'S FAVORITE-Originated in Johnson County, Missouri; very large, golden-yellow, with bright red cheek; nearly sweet, fine flavor, very aromatic; one of the best and highest selling market apple; tree very healthy and moderately productive; vigorous. November to January.

MAMMOTH BLACK TWIG-Excels Winesap in nearly every important point; a better grower, hardier and the fruit much larger; color even a darker red; flesh firmer; flavor milder, but fully equal. A long keeper.

McINTOSH RED-Season, December and January. A choice variety of the Fameuse type. Tree vigorous with spreading head; a good annual bearer. Fruit above medium to large, highly perfumed; smooth polished yelluw, almost covered with brilliant solid crimson, a beautiful fruit; flesh snow white, crisp, very tender, sprightly aromatic, sub-acid, very good quality.

NORTHERN SPY-Large, roundish-conical, often flattened, slightly ribbed; handsomely striped with red; flavor rich, aromatic, mild sub-acid, fine. Keeps through winter and late into spring. To afford fine fruit, tree must receive good cultivation and atten. tion. A market fruit of highest quality.

NORTHWESTERN GREENING-Season, December to March. Tree a splendid vigorous grower, quite hardy. Fruit large to very lảrge; green, becoming yellowish-green when ripe; flesh yellow, fine grained and firm; flavor a good sub-acid; very smooth and attractive; should be given plenty of room in the orchard to secure large, even fruit. One of the best growers we have in the nursery and in the orchard is very prolific and bears regularly when mature.

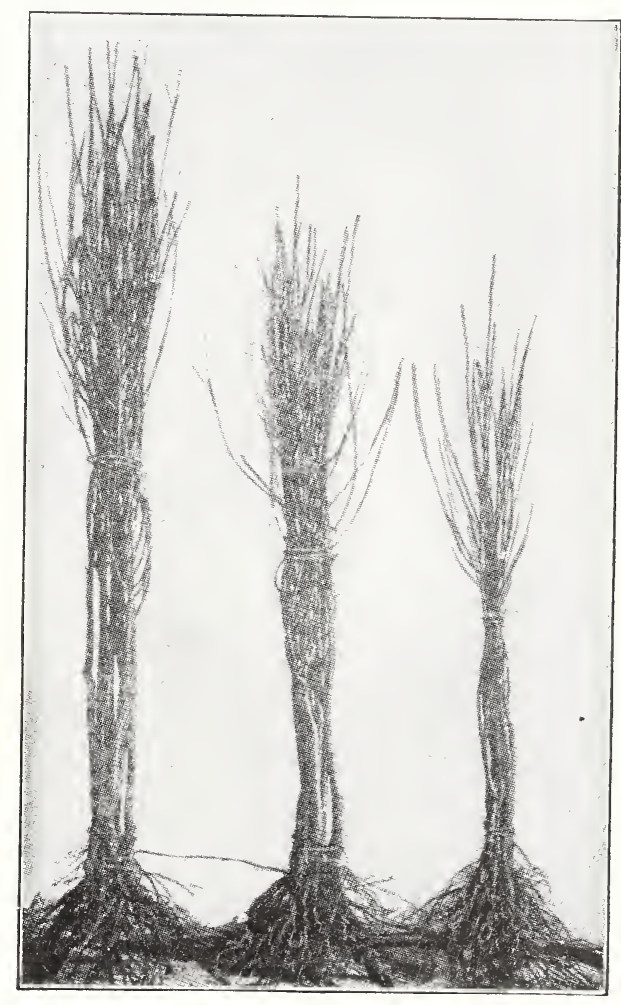

Showing Sizes of trees-5-6 it., 4-5 ft., 3-4 ft. 


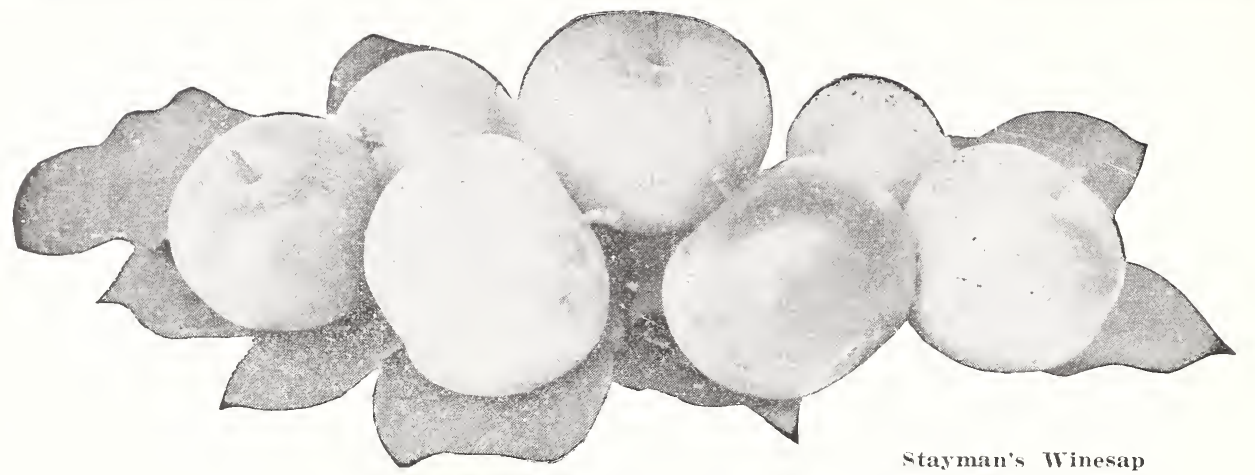

RALLS (Rawles Genet, Geneton).-Medium; has mixed and striped crimson on yellow and green; flavor is mild, vinous and refreshing. Popular as a home fruit. The blossoms appear later than any other sort, and thus they sometimes escape spring frosts. February to April.

RHODE ISLAND GREENING-Season, December to March. Fruit large and handsome, smooth, dark green overspread with yellow. Flesh tender, rich, rather acid, but highly flavored and excellent. Has long been popular in the Eastern states as a dessert apple and also for cooking; tree vigorous, spreading; a heavy and constant bearer after reaching maturity.

ROME BEAUTY-Large, roundish, very slightly conical; mostly covered with bright red on pale yellow ground; flesh tender, not fine grained, juicy, of good quality. Ripens early in winter. The large size and beautiful appearance of this Ohio apple render it popular as an orchard variety. Attains highest perfection on medium soils-land neither too rich, nor too poor.

STAYMAN'S WINESAP-Most profitable market variety. Originated in Kansas and especially adapted to it. It has large size, bright red color, great productireness and hest quality to commend it. The tree is a vigorous grower, is irregular and drooping in habit, and adapts itself readily to different soils and situations. Drouth resisting. Season, November to February.

TOLMAN SWEET-Season, December to March. One of the most popular of the old eastern varieties. Tree is vigorous, upright, spreading and very productive. Fruit above medium; whitish-yellow, often with faint blush on sunny side.

WINESAP-Medium size, dark red, juicy, mild. A favorite late winter apple and a leading commercial variety on all markets, as well as a very popular home apple in the West. Should be planted liberally both in commercial and home orchards south of Nebraska-Dakota state line and east of 100 th principal meridian. Is a high class dessert apple; also good to very good for sauce, pies, jelly and marmalade. December to April.

WINTER BANANA-Fine, vigorous grower, large healthy foliage; early bearer. Fruit medium to large, smooth and handsome, golden-yellow usually shaded with red blush; flesh fine grained, rich, sub-acid, aromatic; highest quality. One of the best dessert apples. A valuable market variety, but bruises easily and is not adapted to long distance shipping.

WOLF RIVER-One of the largest apples grown. Color yellowish-green with stripes and splashes of carmine, very $h$ a $\mathrm{nds}$ s $\mathrm{m}$ and showy; flesh nearly white, firm and rather coarse grained; flavor sub-acid, fair to good. Tree vigorous and fair ly productive. October to January.

YORK IMPERIAL -Medium, oblong, angular, oblique, smooth; yellow shaded red, ind istin et red stripes; flesh yellow, firm, juicy, sub-acid, good. Winter. An excellent shipping apple. 


\section{Crab Apples}

$\mathrm{W}$

ITHIN the past few years a good many people have paid much attention to improving this fruit. Their efforts have been attended with marked success. Crab apples succeed equally well in all sections and are valuable for cider, preserving and jellies, and some of the improved sorts are excellent for eating. Every orchard should contain a few, as the trees are handsome, annual bearers, and usually fruit the second year.

Crab Apples should be planted thirty to forty feet apart. They are very hardy and bear young and abundantly. The fruit makes the finest cider known. Plant and cultivate same as an apple.

FLORENCE-A hardy, spreading tree; bears young and inclined to overbear. Fruit medium; color carmine when well colored; flesh yellowish, medium, fine, acid; excellent for cooking; a fine jelly crab, and valuable for early market, as well as home use. August.

HYSLOP-Season, September to October. Tree vigorous where hardy; blights in some localities. Fruit medium; yellow grounded with heavy shadings of deep crimson and splashes of maroon with heavy blue bloom; flesh fine, firm, yellow, astringent; bears abundantly in clusters, which make tree exceedingly ornamental. Its high color always commands a fancy market price for it. One of the most desirable sorts for culinary purposes.

RED SIBERIAN-About an inch in diameter, grown in clusters; bears young and abundantly. August to September.

TRANSCENDENT-Season, September. Fruit medium to large; color brownish-yellow with blush of carmine; flesh firm and crisp, yellowish, fine grained, very juicy, acid. Tree is a vigorous grower. Hardy. Subject to blight and should not be planted near other orchard trees.

WHITNEY - Season, August. Fruit large to very large for a hybrid; yellow, striped with red and mostly covered with red on sunny side; flesh yellow, very juicy and fine grained; flavor rich and almost sweet.

YELLOW SIBERIAN-Medium, round, golden-yellow. Vigorous grower. Ripens in September.

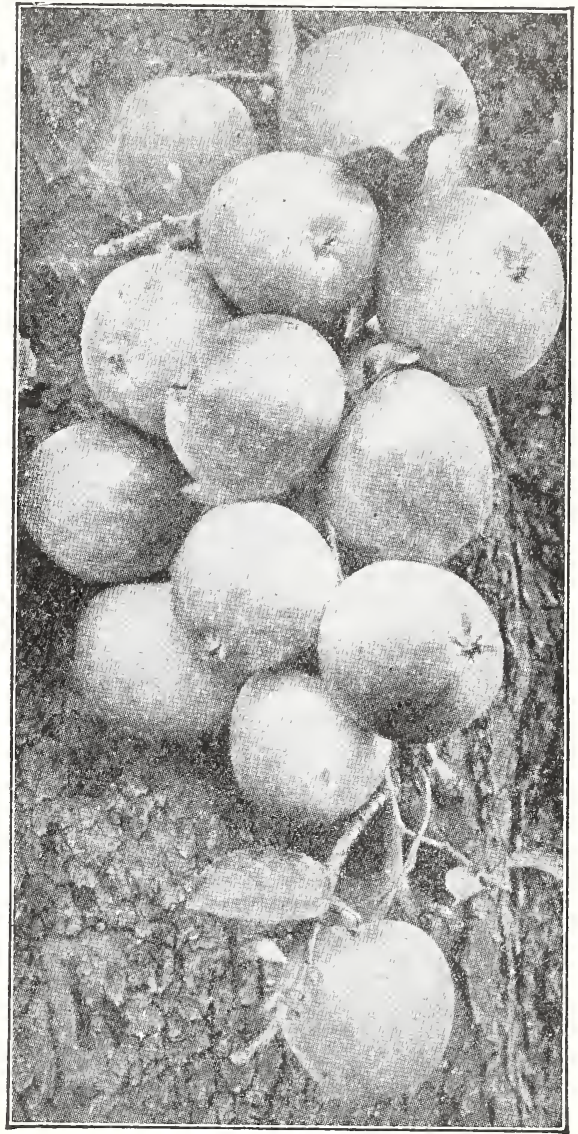

Transcendent

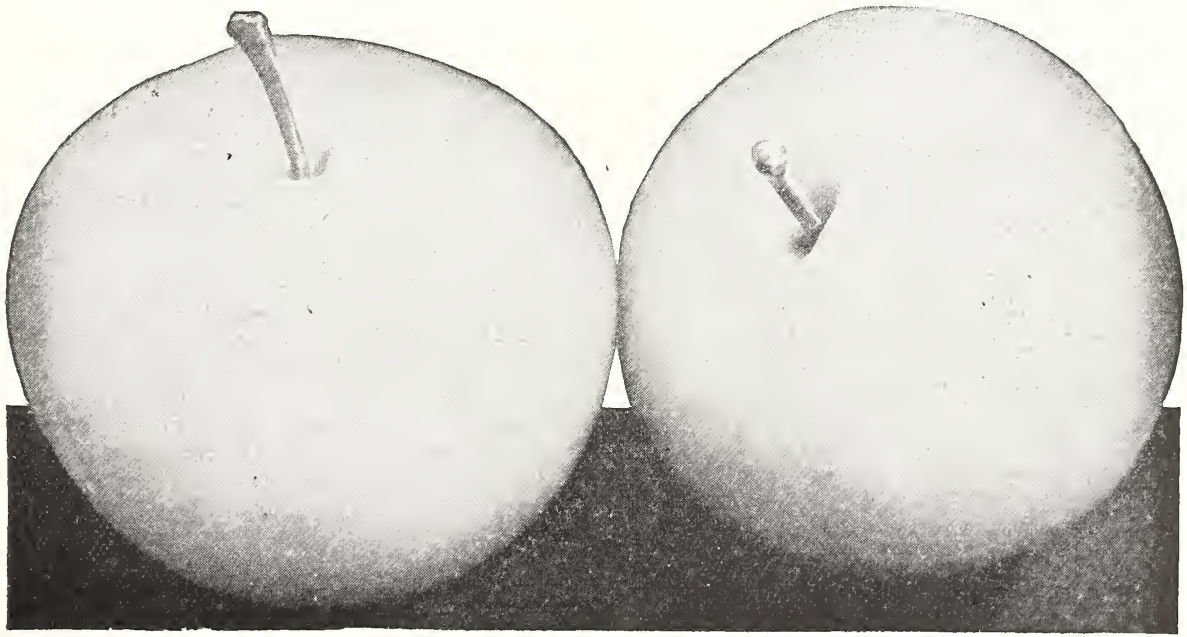




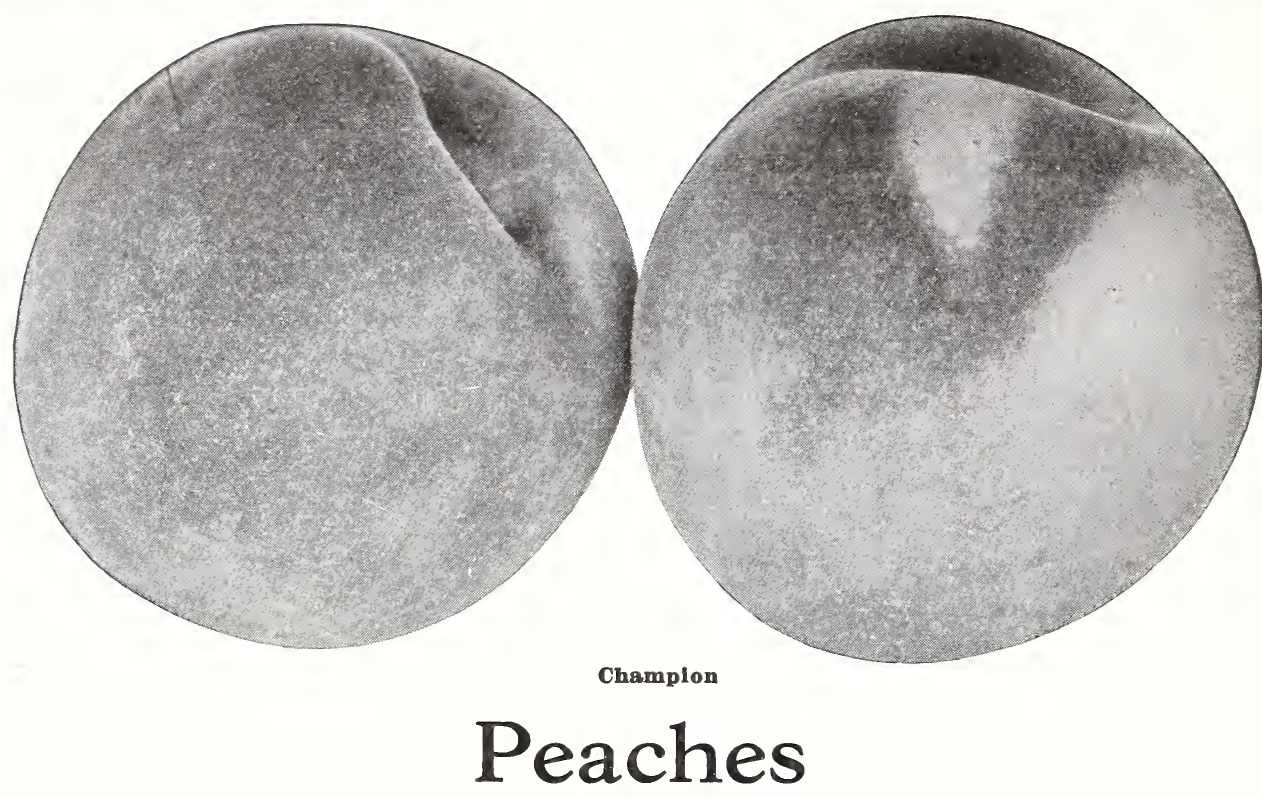

$\mathrm{F}$

EW fruits enjoy a greater popularity than peaches. With delicious flavor they combine attractive appearance and the uses to which this fruit may be put are so many that there are never enough on hand for all. This applies especially to small communities in which farmers and fruit growers can establish a thriving business without serious effort.

Peaches do well in most soils and by carefully following some of the suggestions offered below, trees may easily be established and bring splendid returns in a few years. By selecting varieties which bear early and late the peach season may be extended over a considerable period.

\section{CULTURE DIRECTIONS FOR PEACHES}

Peaches should be planted sixteen to eighteen feet apart. To secure healthy, vigorous and fruitful trees and fine fruit, the following points must be well attended to: First-Keep the ground clean and mellow. Second-Keep the heads low-the trunks should not exceed three feet in height. ThirdGive them an occasional dressing with wood ashes. Fourth-Prune every spring shortening the shoots of the previous year's growth; this keeps the head round, full and

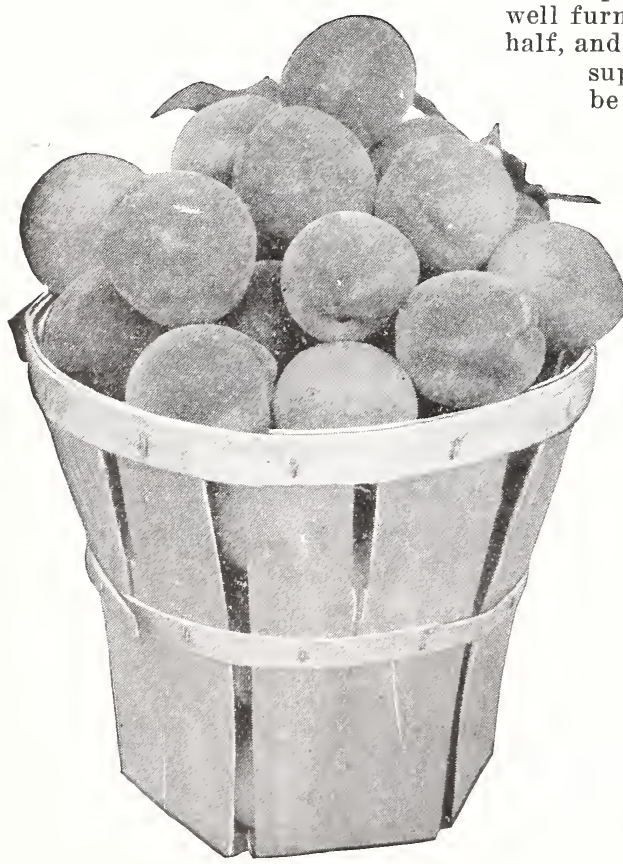

J. H. Hale uply of fruit buds. Sickly and superfluous shoots should e cut out clean. The fruit is borne on wood of last year's growth and hence the necessity of keeping up a good supply of vigorous annual shoots all over the tree. Young trees should be well mulched every spring, or kept well cultivated until about the middle of July each year.

ALEXANDER (Semi-Cling).-Medium size; greenishwhite, nearly covered with rich red; flesh white and juicy; tree vigorous and productive; a good market peach.

BELLE OF GEORGIA-Fruit large size; color red and white; flesh white, firm and highly flavored. This variety has become one of the standard varieties in the big commercial orchards, both North and South. Stands shipping well and brings top prices. In many respects it is equal to Elberta. Tree a rapid grower and very productive. Perfect freestone.

CARMAN (Free)-Large; resembles Elberta in shape; creamy-white with deep blush; skin tough, making it a rood market variety; flesh tender, juicy and fine flavor; a prolific and regular bearer.

CHAMPION (Free)-Large, round, quite regular; yellowish-white mottled with red on sunny side; flesh white with red at the pit; one of the best in quality and a general favorite of great hardiness.

CRAWFORD'S EARLY (Free)-Large, roundish, bright yellow with red cheek; flesh yellow, juicy and sweet; quality good. August and September. 
CRAWFORD'S LATE (Free)-Large, roundish. oval, yellow with broad red cheeks, flesh yellow with red at the pit; melting, vinous and very good. Late September.

CROSBY (Free)-Medium to large, orangeyellow splashed with red; flesh yellow, red at pit, juicy and rich; tree hardy and pro-. lific; fruit should be thinned in order to make good sized peaches; a popular market sort; middle of September.

EARLY WHEELER (Cling)-Here is the best of all early peaches. The tree is hardy, vigorous and very productive. The fruit is of good size and of very showy appearance, being an attractive creamy white, splashed or blushed with red. Flesh white, firm, meaty and of good flavor. The skin is tough and quite fuzzy, making it a fruit that will stand shipping. As a home fruit it is one of the best and is a leading early market peach.

ELBERTA (Free)-The great market peach of the Southwest; perfectly hardy in the North and is believed by many growers to be the best all around peach; color lemon-yellow with blush on sunny side; flesh pale yellow, tender and juicy; tree vigorous; a good shipping peach.

FITZGERALD (Free)-An improved early Crawford fully equal to it in size, quality and color; tree makes a thrifty growth, bears quite young, is productive and very hardy; bright yellow splashed with red; flesh deep yellow and of the best quality; early September.

FOSTER (Free)-Larger than Crawford's Early which it resembles in general appearance. Deep orange red, becoming quite dark on sunny side; flesh yellow, rich and juicy with sub-acid flavor, firm; one of the best for drying or canning.

GLOBE (Free)-Large, flesh firm, juicy, rich and luscious; quality good. October.

GREENSBORO (Semi-Cling) - Large, rather roundish; yellow with splashes of bright red; highly colored in the sun; flesh white, very juicy and a good quality; ripens with Alexander. Fruit is not as apt to rot as many other early sorts. Hardy.

J. H. HALE (Free)-Very large, globular. Color deep golden yellow overlaid with bright carmine. Flesh solid, deep yellow, delicious flavor. Tree very hardy and productive, similar in

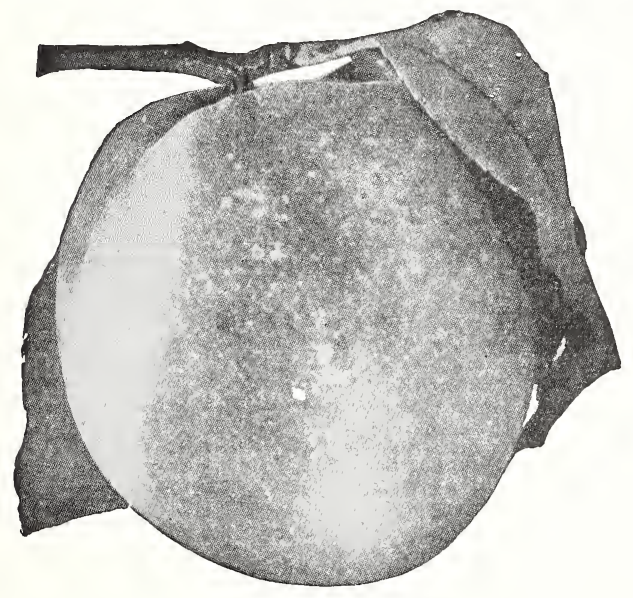

Crawford's Early

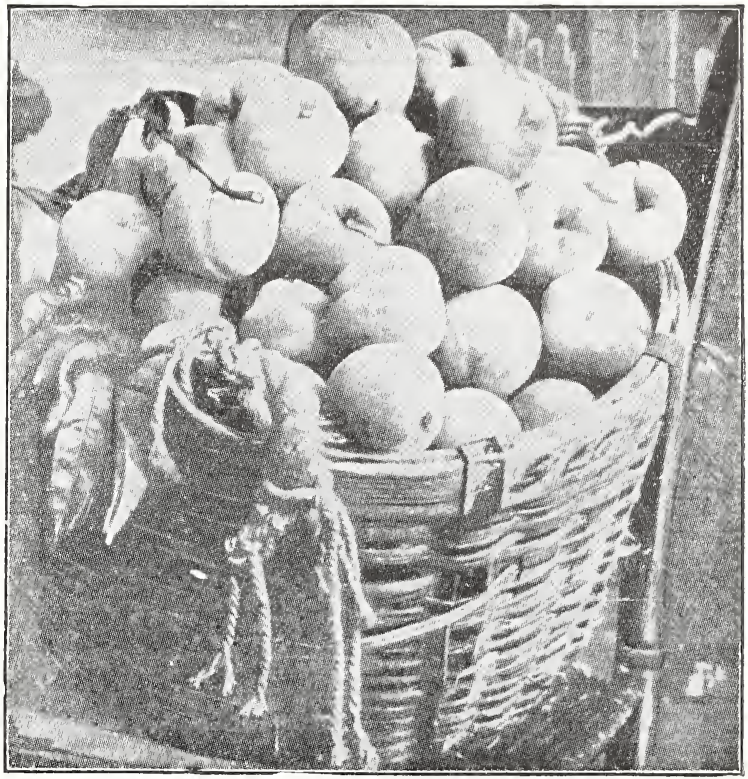

Elberta

growth to Elberta type. An exceptionally fine variety.

HEATH CLING (Cling)-Very large, creamywhite with delicate red blush; flesh white, slightly red at the pit; tender, juicy and sweet; a valuable sort for canning and one that commands fancy prices in all markets. Late September.

MAYFLOWER-Earliest peach known. Ripens one week before Sneed; dark red all over, beautiful appearance. Carries well to market, not being tender like Sneed. Blooms very late, crop never entirely cut off by late frosts. Size medium, quality good. Tree an upright, good grower, a very prolific bearer.

ROCHESTER (Free)-Large yellow and red Peach. Flesh yellow, of fine quality and exquisite flavor. Stone very small and will ship as well as Elberta. The tree comes into bearing when very young, is a strong, upright grower and is as hardy as an Oak. Has produced a full crop after undergoing a temperature of $16 \mathrm{de}$ grees below zero, which killed all the buds on Elberta and Crawford in the same orchard.

SALWAY (Free)-Large, roundish, deep yellow with rich red cheeks; flesh yellow, firm and juicy and sugary; Trees are strong growers and bear plentiful crops. A late market sort.

SNEED (Semi-Cling)-Medium, roundish oval, creamywhite, splashed and mottled with bright red; flesh yellowish-white, tender, vinous and good; free from rot and ripens early.

STUMP (Free)-Medium to large, roundish oval, creamywhite with bright red cheek and abundant bloom; flesh white, very good.

TRIUMPH (Free)-Medium to large, round, somewhat flattened; greenish-yellow, broken striped with purplish-red and pink dots; flesh yellow with red stains, juicy, luscious and very good. One of the early sorts. 


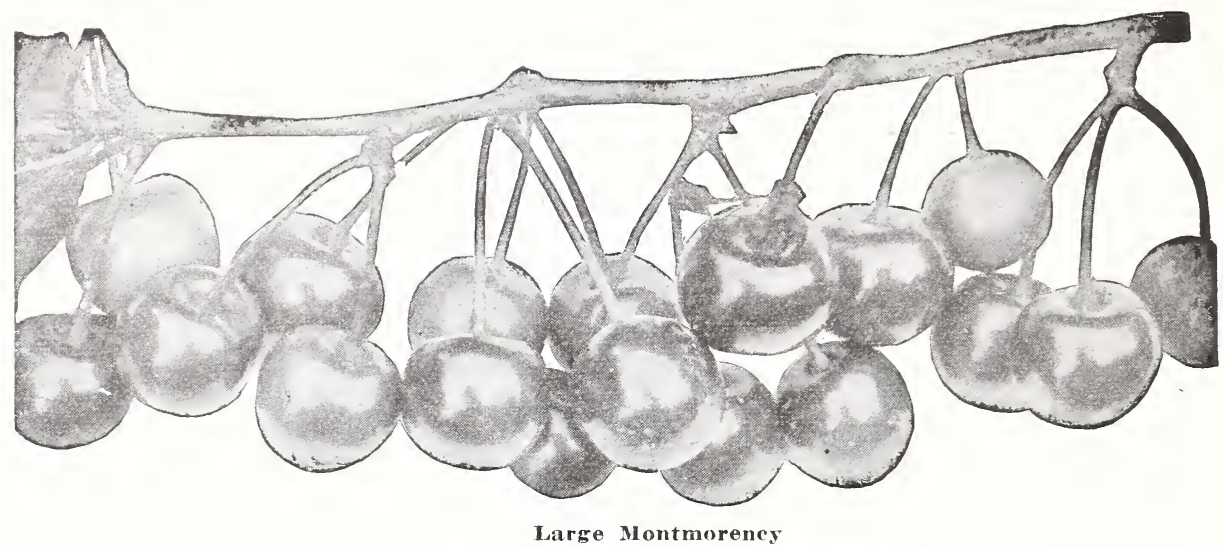

\section{Cherries}

There are few more desirable fruits than the cherry. They are being planted more and more each year and there is always a brisk demand on the market for good fruit.

Cherries thrive in most any dry or well-drained soil. The fruit is delicious whether eaten out of hand or preserved. No home garden is complete without a few cherry trees.

\section{CULTURE DIRECTIONS}

Standard Cherries should be planted twenty feet apart. The soil best adapted to the Clierry is a light loam on a gravelly or sandy subsoil, though it will do well in almost any situation not too wet. To insure a good growth, Cherries should be well cut back for several suceessive seasons.

\section{DUKE AND MORELLO (Sour)}

EARLY RICHMOND-Medium size, dark red, melting and juicy, acid flavor; one of the most valuable and popular of the acid cherries and is unsurpassed for cooking; tree slender grower, exceedingly productive and very hardy; will stand the most severe weather.

ENGLISH MORELLO-Medium to large, roundish; dark red, nearly black when ripe; flesh

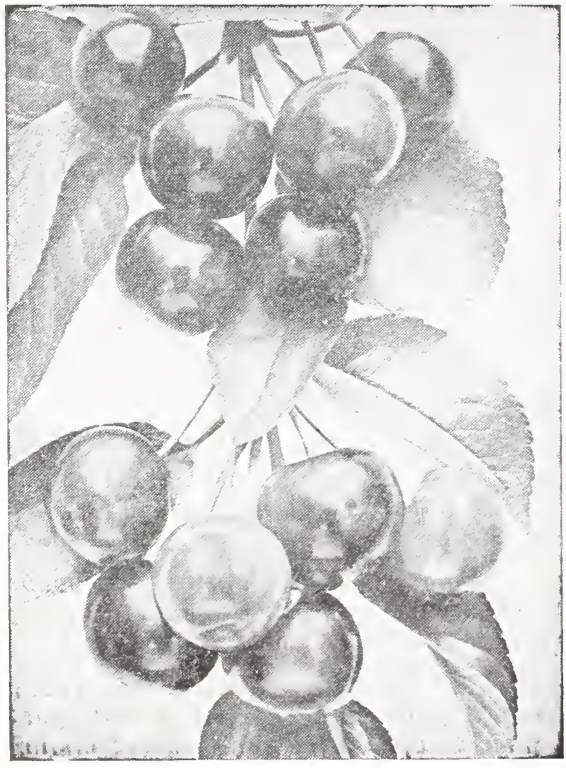

Early Richmond purplish-red, meaty, juicy, slightly antringent and good; very productive.

LARGL MONTMORENCY-Large, roundish, red, flesh tender, mildly acid and better quality than the Early Richmond and about ten days later. One of the popular sorts. Tate June.

WRAGG-Large, roundish, heart-shaped; dark crimson and when fully ripe, blick or nearly so; flesh and juice light erimson, firm and good, very productive; one of the hardiest and is usually a sure cropper.

\section{HEART AND BIGGAREAU (Sweet)}

BLACK TARTARIAN-Very large, bright purplish-black; half tender, juicy, very rich and flavor excellent; treo a vigorous grower and producer. Jume.

GOVERNOR WOOD-Large, rich, light yellow with rod cheek; juicy and sweet. Late June.

LAMBERT-One of the largest known, smooth, glossy, dark purplish-red, with numerous russet dots. Almost black when ripe; flesh dark purplish-red with whitish veins, firm, meaty; flavor sweet, rich and highest quality; form roundish, heart-shaped, tree hardy and vigot. ous a good shipping variety and one of the best for canning.

NAPOLEON BIGGAREAU (Royal Ann)-A beautiful cherry of large size; pale yellow with bright red cheeks; flesh firm, juicy and sweet; one of the best for market and canning. The hardiest of the light-yellow cherries and deservedly popular. Late.

WINDSOR-Fruit large, liver-colored, flesh firm and of fine quality. The hardiest of all sweet cherries and very prolific. A valuable variety for market and for family use. 


\section{Mulberries}

The mulberry is not only valuable as an ornamental shade tree, but the fruit is well worthy of a place in every collection. Plant in deep, rich sandy loam. The tree requires little or no pruning and is of easy culture.

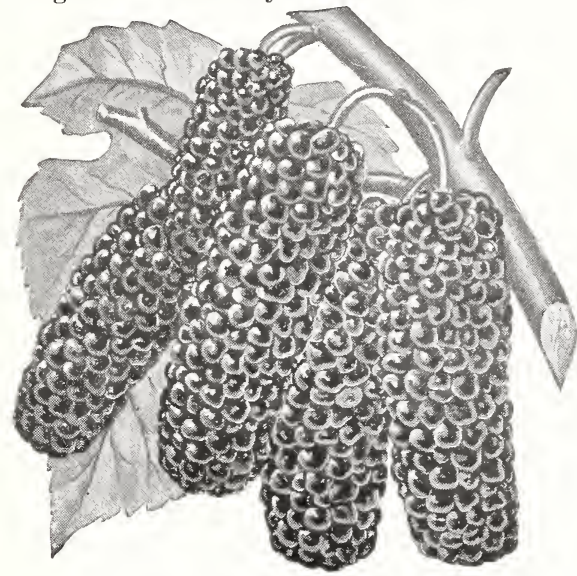

Downing's Everbearing Mulberries

DOWNING'S EVERBEARING-This delicious variety produces a large fruit of a dark, purplish black color; flesh juicy, rich, sprightly, delicious. Very productive and ripening its fruit in succession for a long time. Not hardy North.

NEW AMERICAN-Largest fruit, black; delicious flavor; a very attractive lawn tree, with very large leaves. Of rapid growth. Hardy.

RUSSIAN-Good shade and ornamental tree, rapid grower, excellent wind and snow break; most valuable to supply the native birds, thus keeping them from the most precious fruits. Fruit of little value.

\section{Apricots}

A beautiful and delicious fruit; a close relative of the plum and peach, combining the qualities of both. 'The fruit ripens after the early cherries and just before the plums and peaches. Tree is as hardy as the peach and requires about the same cultivation. It ships well and commands a good price in the markets and for drying and canning it has no superior. The Russian varieties are the most hardy, earliest and most productive. Apricot trees should be planted 15 feet apart each way and

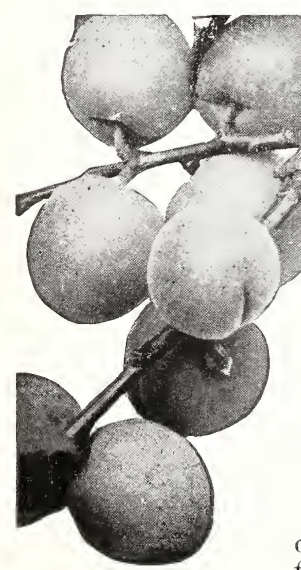
need the same management as peach trees. August.

\section{Compass Cherry-Plum}

This hardy northern fruit was originated in Minnesota and is a cross between the sand cherry of the plains and native wild plum. It will grow and thrive where extreme cold and semi-arid conditions prevail. It usually bears the second year from graft and often nursery trees are loaded down. The quality is much better than that of the sand cherry, having lost much of the astrin gency of this parent in hybridization. The flesh is more firm than that of most native plums, mak ing it valuable for preserving. It is also prized by many to eat from the hand. Every home, especially in the North and West should have some of these trees. They will abundantly bear fruit that will be thoroughly appreciated.

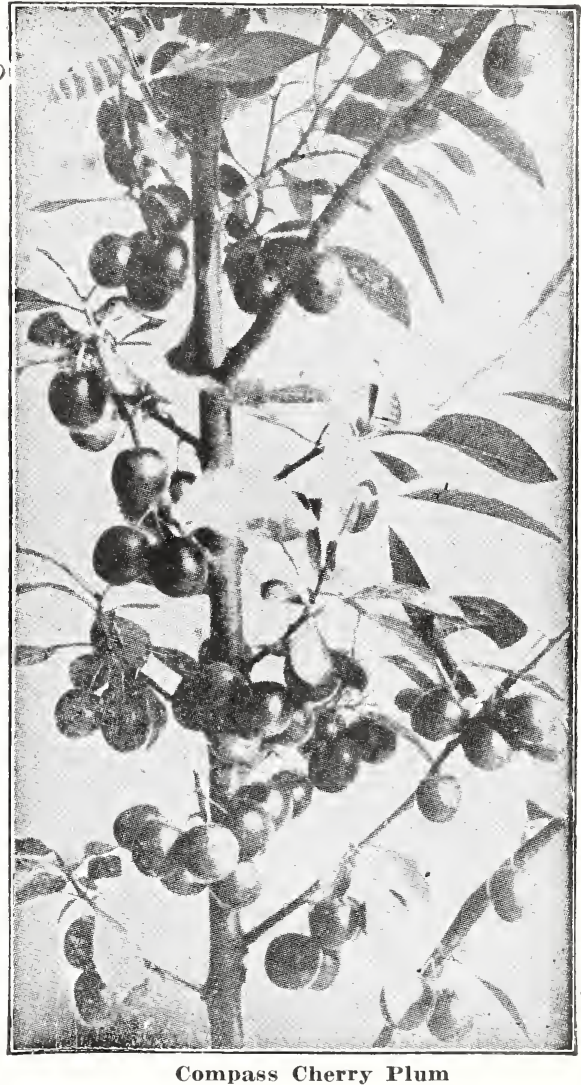

ALEXANDER (Russian)-Medium to small, light orange, yellow flecked with red; flesh tender, juicy, sweet and good quality; hardy; very productive. July.

MOORPARK-One of the largest; orange-yellow with numerous specks and dots; flesh yellow, sweet, juicy and rich; tree is somewhat tender and is inclined to ripen unevenly.

ROYAL-Large, roundish-oval; pale orange with faintly tinged red cheek; flesh yellow, firm, sweet, high flavored, slightly sub-acid and good quality, ripens a week earlier than Moorpark; a good market variety.

SUPERB-Without question the best apricot now being offered. Originated in Kansas and especially adapted to it and adjoining territory. Its points of excellence are in the magnificent tree, which is large and spreading, with broad, glossy leaves. It is perfectly hardy, and in productiveness has no superior. In quality it is better than Early Golden. Color a beautiful yellow with slight blush; flesh firm and solid. One of its many desirable traits is its long season, covering a period of three weeks. 


\section{Plums}

$T^{1}$

HE plum like the pear and other finer fruits, succeeds best in heavy soil with some clay and being almost entirely free from disease, they can be grown very profitably. Of late years the demand for plums has increased very rapidly. The finer kinds are excellent dessert fruits, of rich and luscious flavor; for cooking and canning they are unsurpassed. For home consumption they should be gathered a few days earlier. Some of the varieties are inclined to overbear and should be thinned in order to produce perfect fruit. Most all the varieties, especially the native sorts, are extremely hardy and resist the most severe weather.

Plums should be planted eighteen feet apart in rich soil, which should be kept well cultivated.

\section{European Plums}

REINE CLAUDE or GREEN GAGE-Superior in quality to all other plums in this class; its flaror is unique and delicious. Large, greenish yellow. The tree is remarkably prolific, but a moderate grower. August and September. See illustration on page 11.

BRADSHAW-Very large, dark violet-red; flesh yellowish-green; juicy and pleasant; tree vigorous, erect and productive. August.

DAMSON-Deep purple fruits of delicious quality. One of the best for marketing as it stands handling well. Tree vigorous, hardy and resists disease in a remarkable fashion.

GERMAN PRUNE-A valuable Plum of fair quality for dessert, but most esteemed for drying and preserving. Large, long-oral, purple, with a thick blue bloom; flesh firm, sweet and pleasant, separating from the stone. Moderate to vigorous in growth. September.

IMPERIAL GAGE-Large, oval, yellowish-green with marbled green stripes, heavy white bloom, flesh greenish, juicy, melting, rich and best quality; tree upright and vigorous. September.

LOMBARD-Medium, roundish-oval, violet-red, juicy and pleasant; adheres to stone, valuable market sort, hardy and adapted to light soils; a reasonably sure cropper. See illustration on page 11.

MOORE'S ARCTIC-Grows in large clusters, large, dark purple; flesh very fine; splendid for preserving and dessert; tree vigorous and prolific; fruit is a long keeper.

SHROPSHIRE DAMSON-One of the best for preserving, flesh amber colored; juicy and spicy; tree vigorous, hardy and an abundant bearer.

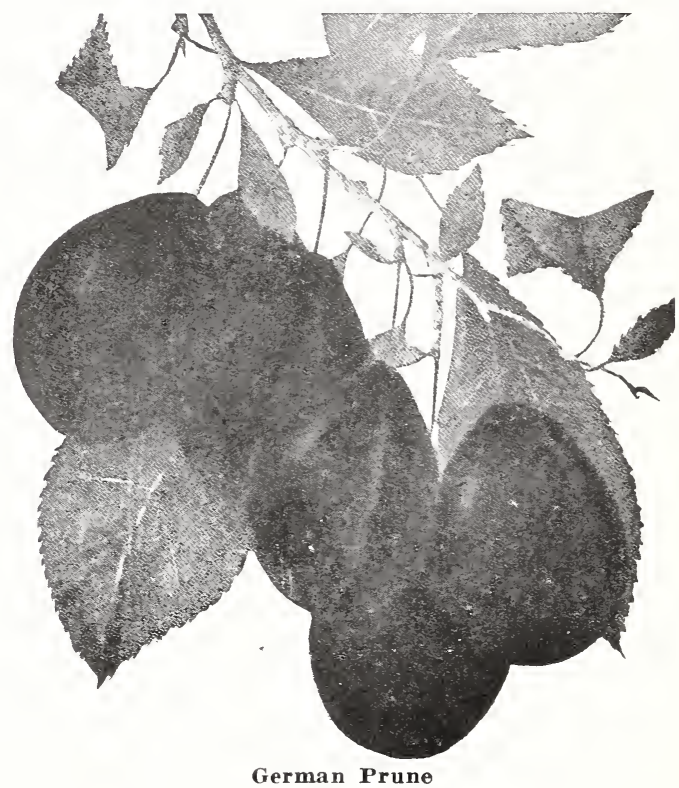

SHIPPER'S PRIDE-Large, nearly round, dark purple, juicy and sweet; splendid shipper and good market rariety; tree moderate grower, but productive.

YELLOW EGG-Tery large and beautiful egg shaped yellow plum; a little coarse but excellent for cooking; tree a free grower and very productive; late August.

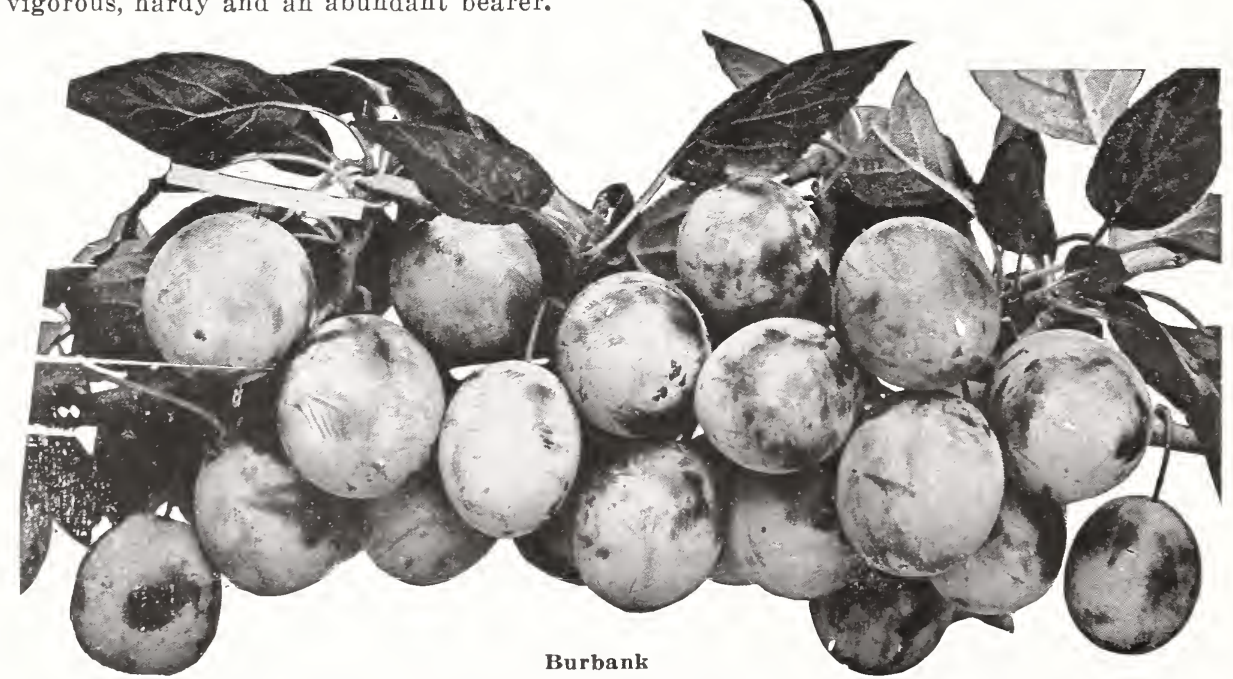

See description on page 11. 


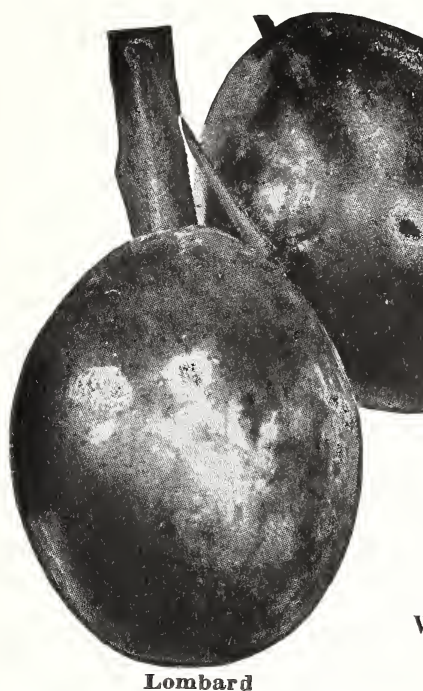

See Description on Page 10.

\section{Japan Plums}

ABUNDANCE - One of the best Japan Plums. Tree is very rapid grower, healthy and comes into bearing quite young and yields abundantly; medium size, rich, bright cherry red with distinet bloom and highly perfumed; flesh light yellow, juicy and tender, and excellent quality. Tree vigorous and hardy.

BURBANK-Medium to large, orange-yellow, dotted and marbled with red; flesh meaty, yellow, sweet and good; valuable for canning and a good market plum. MidJune. Hardy and most prolific of the Japan varieties. See illustration on page 10.

RED JUNE-A very handsome plum, about a week earlier than Abundance. By all odds the best Japanese plum ripening before Abundance. Medium to nearly large size, deep vermilion red, with handsome bloom and very showy; flesh light lemon-yellow or whitish, firm and moderately juicy, very slightly sub-acid to sweetish, of good, pleasant quality; pit small; tree upright, spreading, vigorous and succeeds in all sections of the country.

WICKSON-Large, heart shaped, deep maroon red; flesh very firm, yellow, sub-acid, rich and good; a good shipping plum; tree upright, but in some localities a shy bearer.

\section{Native Plums}

DE SOTO-Resembles $\mathrm{M}$ i $\mathrm{n}$ e $\mathrm{r}$ in form and color, but two weeks earlier. Fine for eating or can. ning. Tre e a moderate grow. er; bears young and profusely; hard y north. Is best planted on moist rich ground and the fruit thinned. Use this variety for fertilizing.

\section{FOREST GARDEN-}

A strong growing tree; needs a little attention to keep

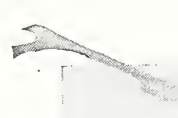

tree in shape to avoid splitting and breaking the limbs. A profuse bearer and perfectly hardy; nearly round, mottled red and yellow, rich and sweet. August.

HAMMER - Large, oblong, light red, of fine quality; profusely fruitful; season late; fine for canning or market.

HAWKEYE-One of the best. Large, color light mottled red, superior quality, firm; carries well to market. Tree hardy, thrifty; annual bearer. A splendid fe-tilizer. September.
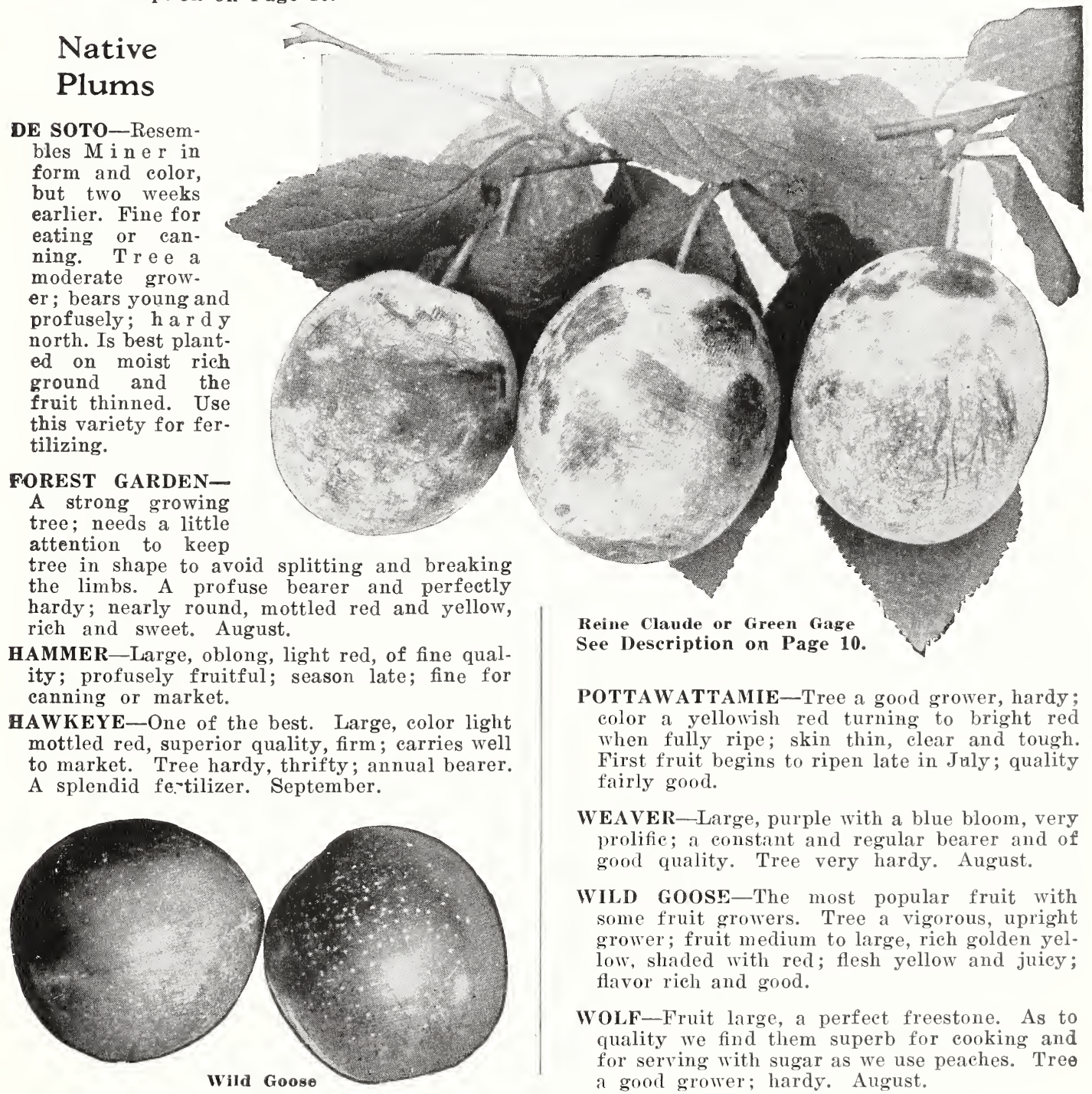

POTTAWATTAMIE-Tree a good grower, hardy; color a yellowish red turning to bright red when fully ripe; skin thin, elear and tough. First fruit begins to ripen late in July; quality fairly good.

WEAVER-Large, purple with a blue bloom, very prolific; a constant and regular bearer and of good quality. Tree very hardy. August.

WILD GOOSE-The most popular fruit with some fruit growers. Tree a vigorous, upright grower; fruit medium to large, rich golden yellow, shaded with red; flesh yellow and juicy; flavor rich and good.

WOLF-Fruit large, a perfect freestone. As to quality we find them superb for cooking and for serving with sugar as we use peaches. Tree a good grower; hardy. August. 


\section{Hansen Hybrid Plums}

TEW plums introduced by Professor Hansen of the South Dakota Experiment Station at Brookings, who has originated many new fruits which are of great value and importance to all sections of the country. One important feature of these Hybrid Plums is their good quality, extreme hardiness, prolificness and early bearing.

HAXSKA-This is a cross between the natire Plum and the fine fragrant Apricot Plum of China. The fruit is splendid for eating out of the hand, and when cooked retains the Apricot flaror. The size of the fruit is about one and one-half inches in diameter. The color of the fruit when ripe is bright red, with a hears blue bloom; flesh is firm, rellow, good quality and rery fragrant. It begins to bear the second Fear, ripens in August. Its ralue for preserves will make it popular and desirable ererymere. There is a tremendous demand for this rariets, and we hare been unable to meet the demand to date.

OPATA-One-rear-old trees set fruit buds freelr. No. 1 trees transplanted will bear the next rear. This rariets is a cross between the sand Cherry and the Gold Plum, a cers large plum, for which $\$ 3,000$ was paid when first introduced. The tree resembles the plum in its habit of growth. The fruit is one inch or more in diameter; small pit. It is a dark purplish red, with blue bloom, flesh is green and firm; flaror pleasant, partakes of the rich streetness of the Gold Plum. It is excellent for eating out of the hand as well as for table and cooking purposes. Bears as early as the first week in August. This is greatly in its faror, as at that season there is rers little fruit of anr kind. Tree hardy and a great bearer certainly makes it popular whererer planted.

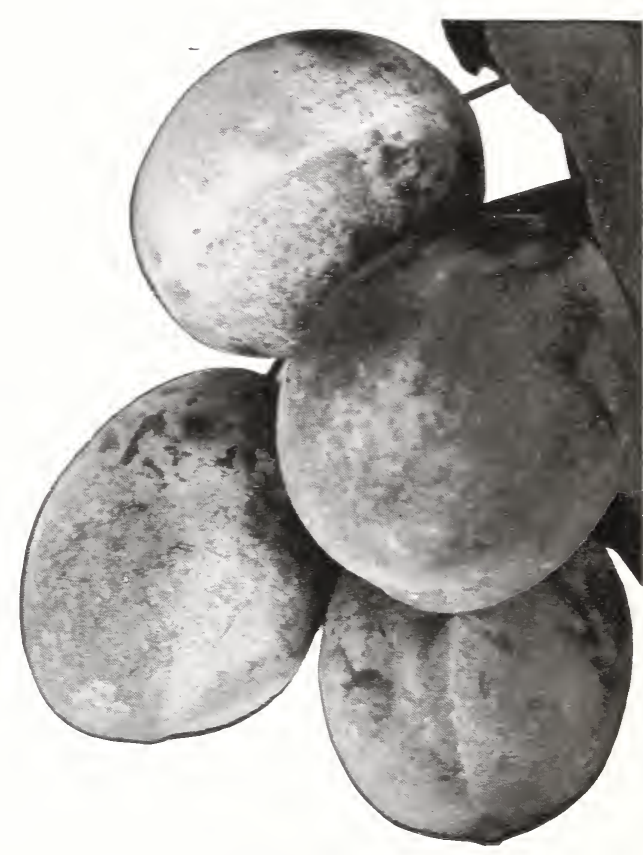

Hanska

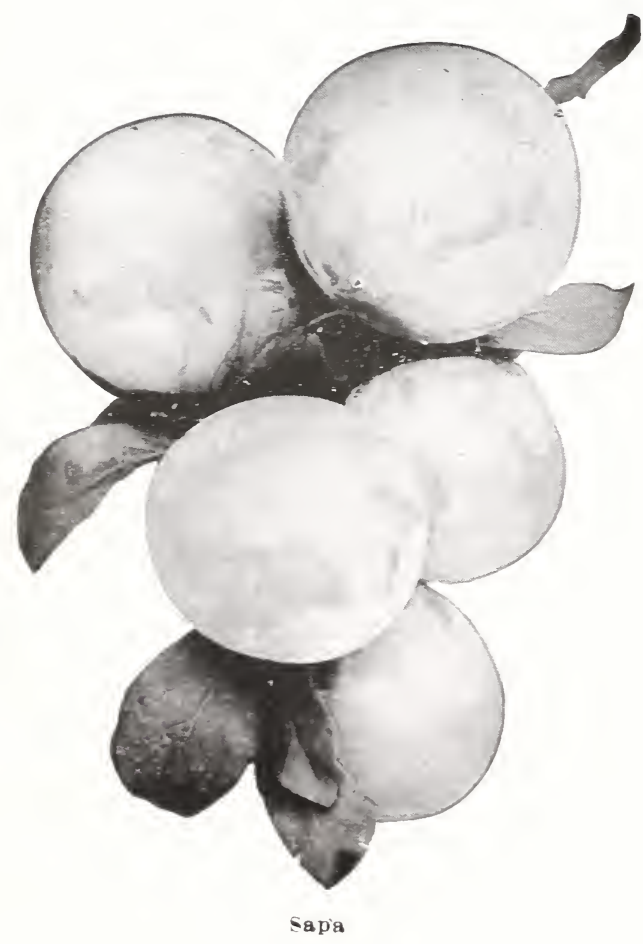

SAPA-Introduced in 1905. Fruit has a glossr, dark purple, thin skin, rich dark purple red flesh of the Sultan Plum. On account of its fine flaror and rich coloring Sapa has headed the list of these Hrbrids in popularity. Excellent eating out of the hand, and makes the most delicious. rich. street, deep wine col. ored sauce. It is a wonderinlis earls and prolifie bearer. Specimens gromn in Minnesota on one-rearold trees in the rear 1909 took first prize as a seed. ling plum at the Minnesota state Fair of that rear. Fruits are borne in clusters around the branches, and three-rear-old trees hare borne as high as one and one-hali bushels. Tree is spreading and handsome in appearance.

WANETA-This wonderful big ner Plum is the latest of Professor Hansen's productions, and gires the northern orchardist his first opportunity to compete with California in growing large market plums. The following is Professor Hansen's description: 'Mr belief is that in this rarietr I hare combined the best points of the natire and Japanese Plum. It is the largest of 10.000 seedlings. In size it is two inches in diameter and weighs two ounces. The female parent is the apple plum, a large Japanese rariets. The male parent is the Terrs, the largest of the natire rarieties. We regard this as the most promising plum that has been offered to our planters since the settlement of the country. All the reports coming in from those who hare tried it describe the Waneta as bearing early and producing the largest fruit that has been raised in their locality." 


\section{Pears}

7 HE Pear very justly ranks as one of the most delicious of fruits, by reason of its fine, juicy texture and exquisite flavor and aroma. Of late years much attention has been given to its culture, and those who have intelligently cultivated it for market have found it to be a profitable occupation.

The soil most congenial to this fruit is a strong clay loam, but it will succeed in any good soil, provided it is moderately rich and dry. A soil saturated with stagnant moisture for a large portion of the year is totally unfit for this purpose. The usual distance for planting is about twenty-five feet each way, but if the soil is very strong, twenty feet is sufficient.

Early and Autumn Pears should be picked ten days before fully ripe and allowed to ripen in the house. This greatly improves the flavor of all kinds, while some are nearly worthless if allowed to ripen on the tree.

\section{Summer Pears}

BARTLETT-Large size. Golden yellow when ripe, with a beautiful blush next the sun. Buttery, very juicy, and highly flavored; tree a strong grower, bears early and abundantly; very popular. August, September.

CLAPP'S FAVORITE-A large fine pear resembling the Bartlett, but without its musky flavor; pale lemon-yellow with brown dots, and fine texture, melting, buttery, juicy with a delicate flavor; tree hardy and productive. August and September.

WILDER-Medium to small, greenish-yellow with a brownish-red cheek; melting, sweet and very pleasant; tree vigorous and starts to bear quite young.

\section{Autumn Pears}

ANJOU (Buerre d'Anjou) - A large fine pear, buttery and melting with sprightly flavor; tree a fine grower and very productive; one of the best. October to January.

DUCHESS D'ANGOULEMF-Very large, greenish yellow, sometimes russeted; makes a beautiful tree and heavy bearer, buttery, melting and sweet. A dependable cropper and good market sort. October and November.

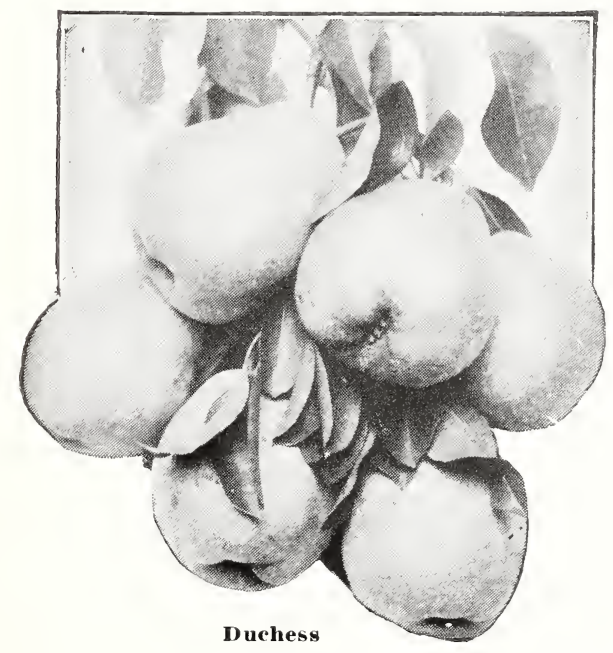

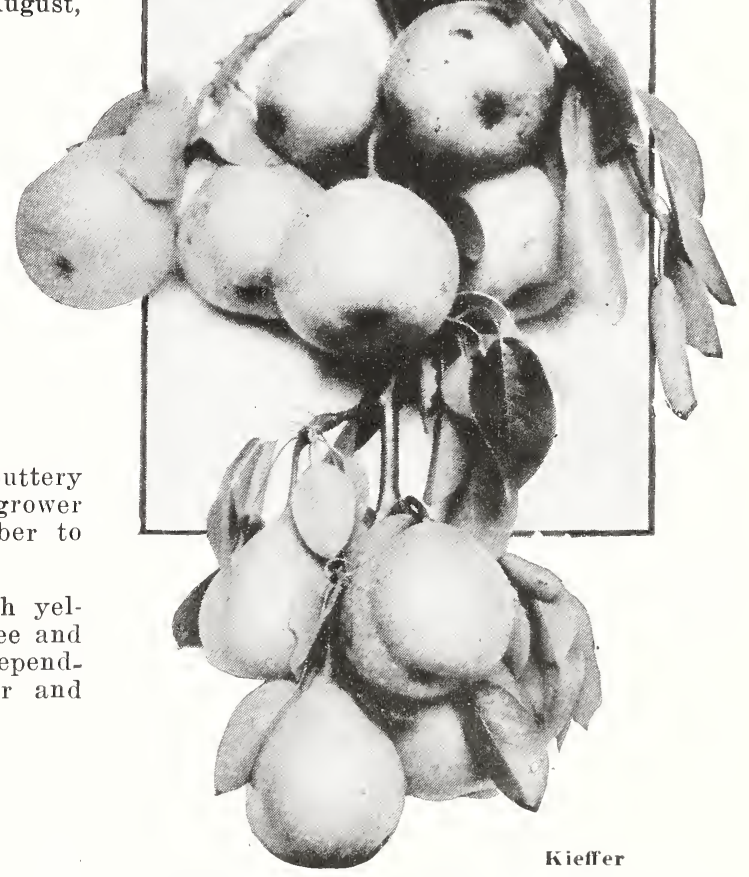

FLEMISH BEAUTY-Large, juicy, melting and rich; strong grower and good bearer; very hardy but prefers sunny situation. September and October.

GARBER-Large, bright yellow with red, juicy and good; a splendid canning pear, tree vigorous and hardy, not subject to blight; ripens just after Bartlett.

KIEFFER-Large; golden yellow, often blushed in the sun; juicy and melting. One of the best for canning and preserving; the most profitable to grow. Tree healthy, hardy and vigorous. Does not succeed on quince, therefore no dwarfs should be planted. Kieffer receives more praise and condemnation than any other. It is liable to overbear, therefore special pains should be taken to thin the fruit.

SECKEL-Small, rich, yellowish-brown; one of the best flavored pears known; very productive. September and Oetober. 


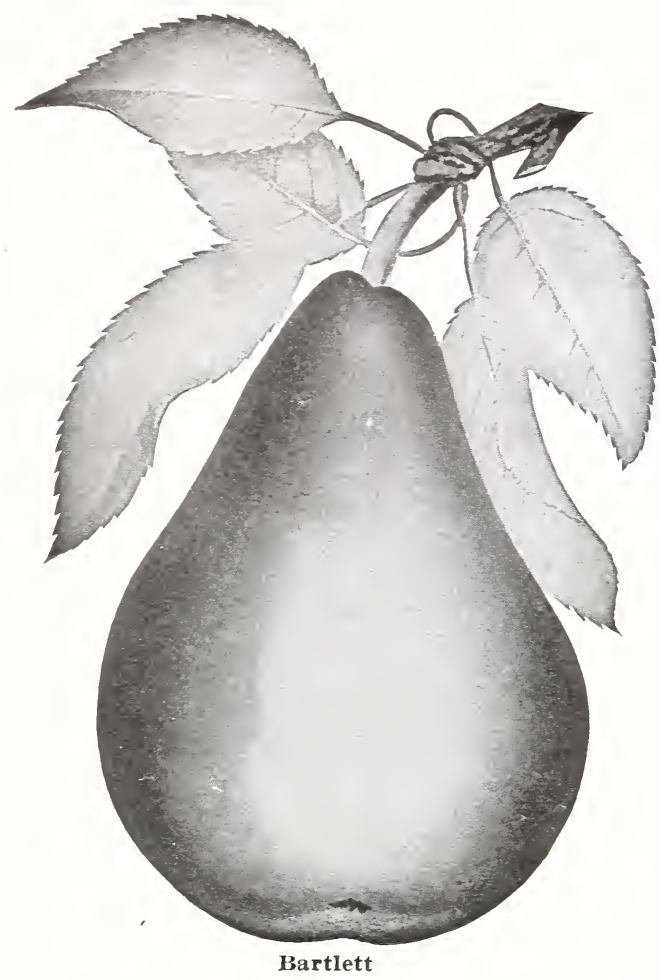

\section{Dwarf Pear Trees}

The pear is one fruit that can be grown profitably as a dwarf tree. It differs from a standard tree in that it is grafted on a quince root. This retards its growth and makes a dwarf tree. This slower growth makes it more resistant to blight and other pear tree troubles than the standards, which grow more rapidly. It also causes the tree to bear earlier; some times producing fruit the second year, and often quite heavily the third and fourth years after planting. They may be planted much closer (10 to 12 feet apart) than the standards, which makes them rery desirable for city planting and for a limited space on home grounds. The Duchess, Anjou, Bartlett, and Seckel, are the best suited varieties for dwarfing. A few dwarf pear trees should be in every home orchard or garden in the Middle West.

\section{Autumn Pears-Continued}

SHELDON-Large, yellow or greenish-russet with fine red cheek; flesh a little coarse, melting, juicy and crisp, highly perfumed, tree rigorous and productire. October.

VERMONT BEAUTY-Of medium size, roundish, yellow, hearily shaded with carmine; flesh exceedingly fine, sweet and juicy. The tree makes a strong, healthy growth and bears good crops. October.

WORDEN-SECKEL-A seedling of the Seckel, but larger and firmer. Color golden-yellow with bright crimson cheek; flesh white, juicy, buttery, fine grained and melting, tree an upright, vigorous grower. Tery hardy and an abundant bearer.

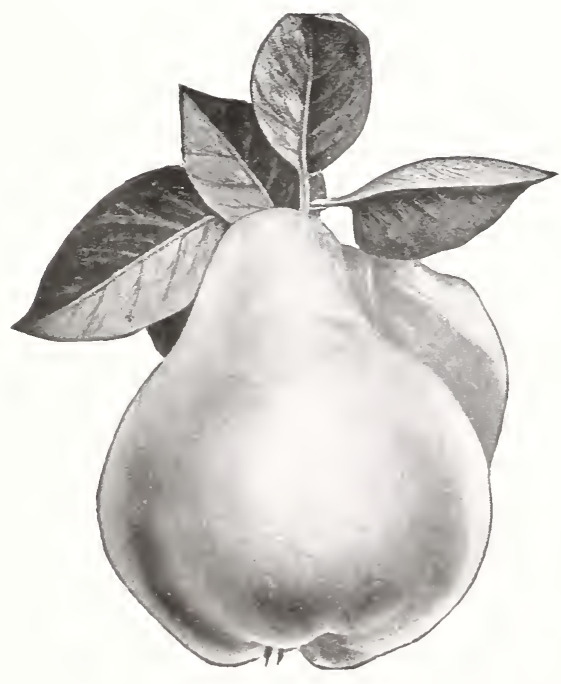

Champion Quince

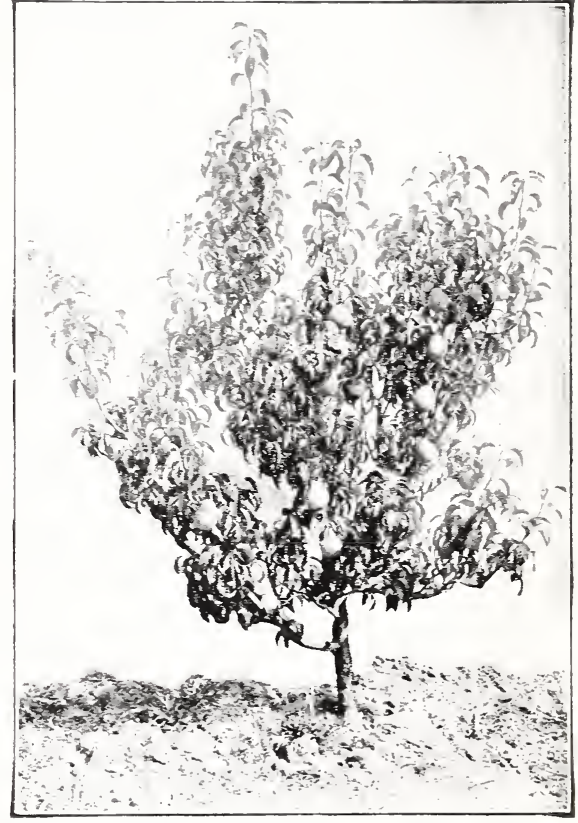

Dwarf Pear Tree

\section{Quinces}

The Quince is attracting a good deal of attention as a market fruit. The tree is hardy and compact in growth and requires little space; is productire, bears regular crops and comes into bearing early; the fruit is much sought for canning. When put up in the proportion of one quart of quinces to about four quarts of other fruits, it imparts a delicious flaror. It will grow in any good garden soil which should be kept mellow, well enriched; fruit should bo thinned out if it bears too freely.

CHAMPION-Tery large and handsome; flesh cooks as tender as an apple without hard spots; flaror delicate; tree very handsome and bears abundantiy. One of the most raluable sorts. Color greenish-rellow.

MEECH'S PROLIFIC-Tery large, bright rellow, quality rers good, quite fragrant; bears early and is rery productive. One of the best. Mid-summer.

ORANGE-Large, roundish. somewhat irregular with a small and short neck at the base; fine golden-rellow flesh and of excellent flaror. October.

REA'S MAMMOTH-Tery large, roundish, color yellow with pinkish shades, excellent quality: tree a strong grower, dark foliage; bears well and early. 


\section{Blackberries}

$\mathrm{B}$

LACKBERRIES are among the best-known and most valued of our berries. No fruit of any kind is more wholesome. A liberal use of berries and other good fruits will save doctor bills. Blackberries should be planted in rows six or seven feet apart, three to four feet in the row. Keep the ground light, rich and clean, and pinch the canes back when they have reached four feet in height. The demand for blackberries is always good.

\section{CULTURE OF BLACKBERRIES}

Blackberries require the same kind of soil and treatment as Raspberries, except that they should be planted in rows eight feet wide and four feet apart in the row. A neat and improved method of pruning will make the plants self-sustaining bushes, viz.; as soon as the plants are about four feet high, elip off the points of the growing cane and repeat the operation several times, until they assume the form of a bush. If not pruned in this manner they require to be tied to a stake or wire trellis. Mulching is of great advantage to both Raspberries and Blackberries.

BLOWERS-Originated in the celebrated small fruit belt of Chautauqua County, New York, where it has been thoroughly tested for several seasons. Claimed to be the hardiest, most productive, the finest quality, and to bring on the market the highest price of all blackberries. Large size, jet black, good shipper, best quality and unexcelled productiveness are the main characteristies of this splendid new sort.

EARLY HARVEST-One of the earliest, berry medium sized, good quality and very prolifie; firm and attractive in appearance. A good market sort.

ELDORADO-Vine is vigorous and hardy; berries are very large, black, borne in clusters; ripens well together; sweet, melting and pleasing to the taste.

ERIE-One of the best round, large blackberries; absolutely hardy, very black, firm and solid; ripens early.

MERSEREAU-Remarkably strong grower, upright, producing stout stocky canes. Claimed to be the hardiest blackberry, standing unin-

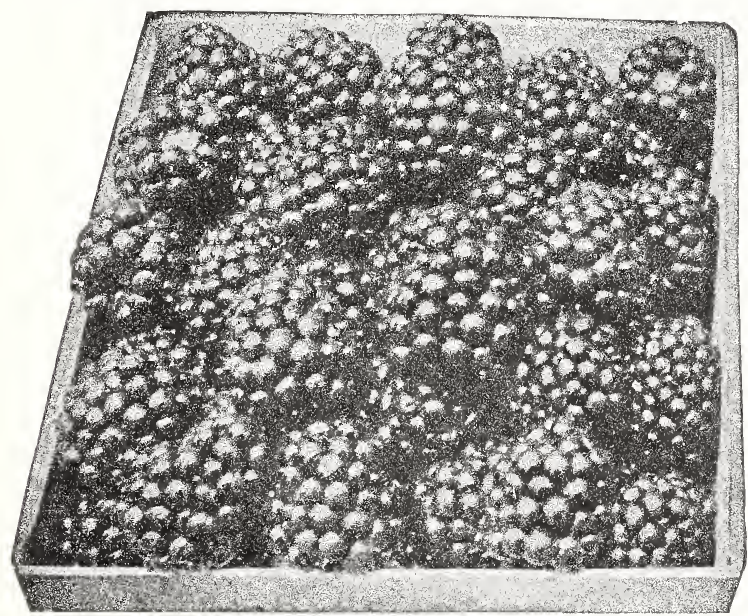

Lueretia Dewberries

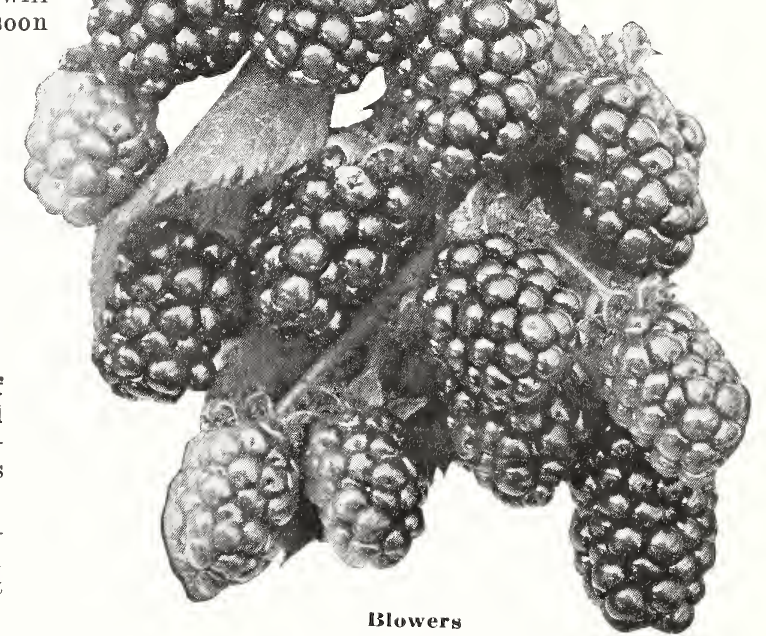

jured twenty degrees below zero without protection. An enormous produeer, of extra size berries, which are brilliant black and retain their color under all conditions; extra quality; rich and melting, without core. Unsurpassed as a shipper and keeper. The season is early mid-summer.

RATHBUN-A strong, erect grower, and hardy; fruit is sweet, luscious, without a hard core; high flavor; jet black, small seeds; firm enough to ship and handle well. One of the largest size berries. Especially valuable for central and southern territory.

SNYDER-The hardiest blackberry known; fruit medium sized and of great quality; a standard market variety.

\section{Dewberries}

The Dewberry is a dwarf and trailing form of the Blackberry. The fruit is highly prized as a market fruit owing to its large size and fine quality. Set the plants two feet apart in the row and cover in winter with coarse litter. Should be mulehed in the spring to keep them off the ground.

LUCRETIA-Perfectly hardy and remarkably productive; said to be the best of this class of fruit; ripens early, is often one and onehalf inches long by one iilch in diameter, sweet, luscious and melting, this variety is recommended most highly. 


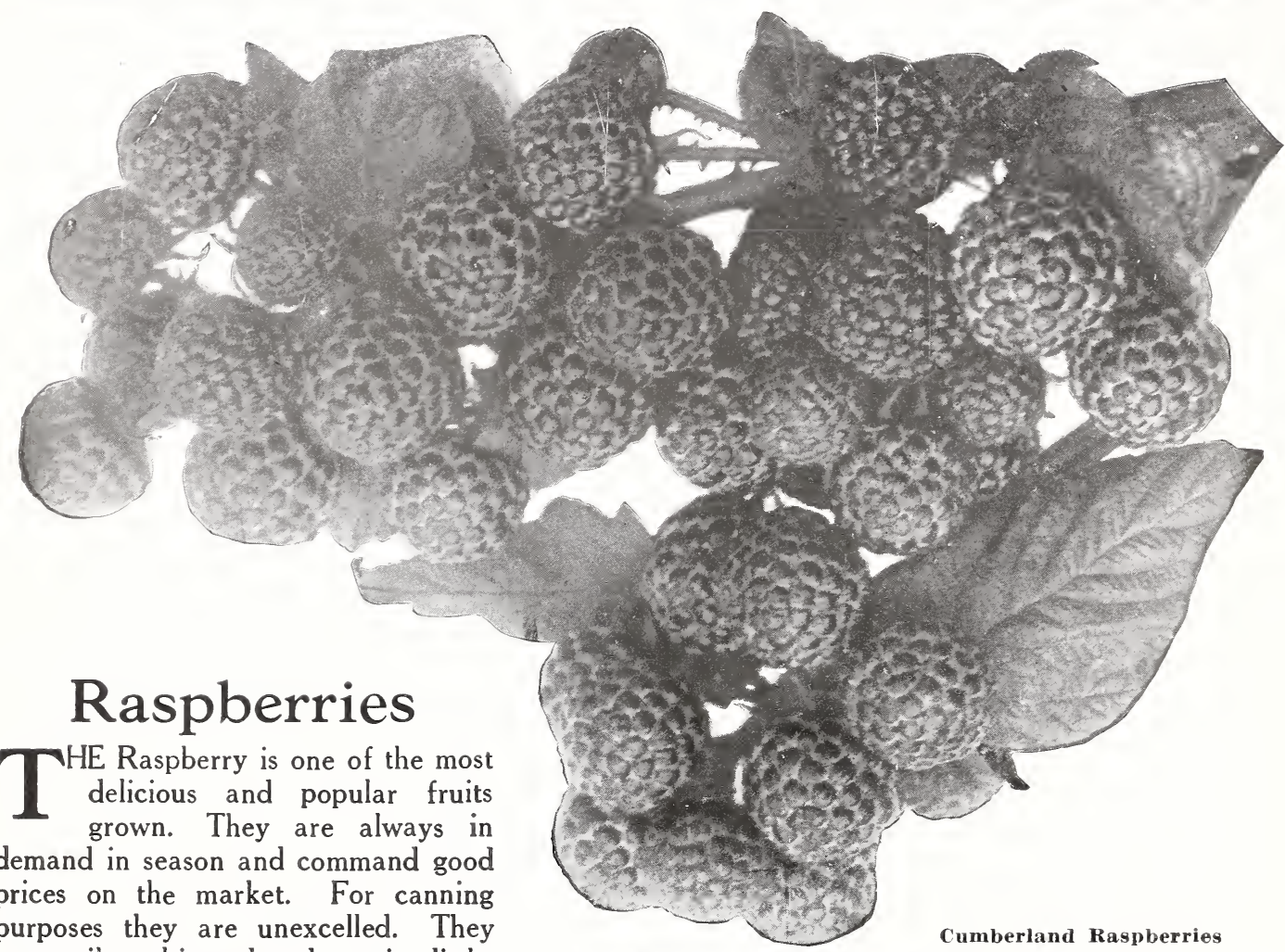

are easily cultivated and require little care.

\section{CULTURE OF R.ASPBERRIES}

Should be planted four feet apart each way or rows five feet apart and three feet apart in row and in a deep soil-one that will retain moisture well in drouth. In training allow only a few canes to grow from each plant, cutting away all suckers to throw the strength into the stalk for bearing; all old canes should be removed immediately after the fruit is all picked. Cut out the old and weak shoots each year. For winter protection, bend the canes over and cover with straw or leaves and remove early in the spring.

CARDINAL (Purple)-One of the new sorts; is extremely hardy and productive; fruit is rich, red and highly flavored. It is the opinion of leading horticulturists that it is the best of the good varieties now being grown.

CUMBERLAND (Black) - The largest of all black cap; healthy, vigorous grower, throwing up stout, well branched canes that produce immense crops of magnificent berries. Fruit very large, firm, quality about the same as Gregg; keeps and ships well as any of the blacks. The most profitable market variety.

CUTHBERT (Red)-Large, bright scarlet-crimson, excellent quality, firm, juicy and refreshing, vigorous grower, hardy and productive; very popular as a home garden and market berry.

KANSAS (Black)-Large, round, firm, moderately juicy, strong grower and very productive; ripens early; considered one of the best market berries on account of handsome appearance.

ST. REGIS EVERBEARING (Red)-The new everbearing variety. It gives a crop of fruit all summer and autumn fruiting on the old canes in generous quantities until late in August. By this date berries begin to ripen on the young canes and continue until late in autumn. Berries are a bright crimson of large size and of surprising quality, sugary with full raspberry flavor. It succeeds upon all soils, whether light and sandy or cold heavy clay and the canes are absolutely hardy.

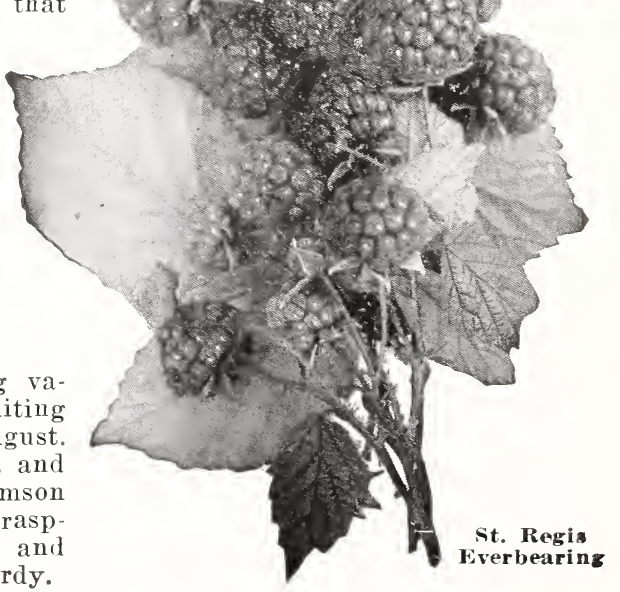




\section{Currants}

7 HE Currant is one of the most valuable of small fruits. They mature just before rasp-

1 berries and can be used either raw or cooked. Being very hardy, they do not winter kill and are easy of cultivation, requiring little care. They can be grown in any good garden soil.

Currants should be planted four feet apart. The Currant flourishes in almost any kind of soil, but to have the fruit in perfection, plant in rich, deep soil, and give good annual pruning and cultivation.

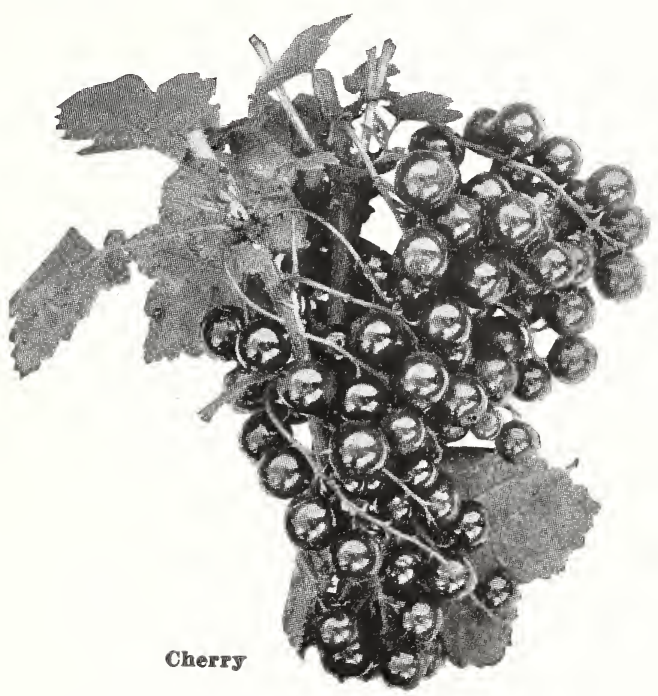

RED DUTCH-Old, well-known sort of good quality; great bearer. Fine market variety. Vigorous and upright grower.

WHITE GRAPE-Very large, yellowish white; sweet, or very mild acid; excellent for the table. The finest of the white sorts, very productive.

W I L D E R - Very large; bright red and attractive; a splendid sort; not so acid as most. Bush very productive; large bunches; ripens $\mathrm{r}$ a th e r early, fruit keeps well.

CHERRY-The largest of all red currants; berries sometimes more than one-half inch in diameter;

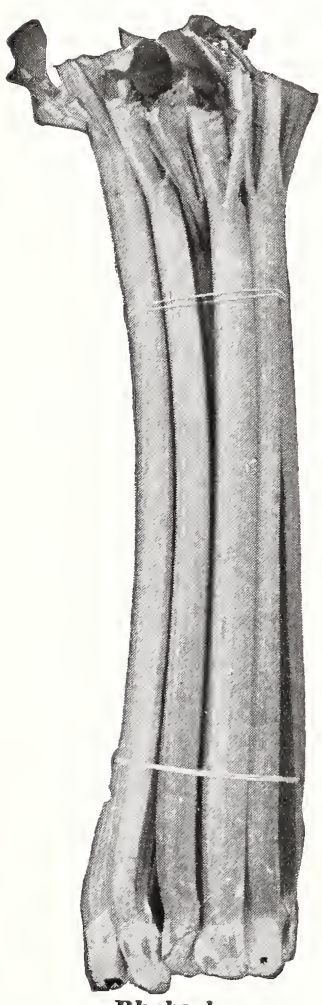
bunches short; plant very vigorous and productive when grown on good soil and well cultivated.

FAY'S PROLIFIC - For size, beauty and productiveness it is a remarkable red currant. The berry is equal to cherry currant, while the flavor is superior. The stem is long, which permits rapid picking, valuable for both market and home. Fruit hangs on well, never dropping, as in other currants.

PERFECTION-Bright red, and of a size larger than the Fay; size of berries is maintained to end of bunch. It is one of the most productive currants. Rich, mild, subacid flavor and having plenty of pulp with few seeds. You can pick Perfections fast as cherries.

\section{Rhubarb or Pie Plant}

This very desirable vegetable comes eaxly in the spring. The large stems of the leaves are used for pie-making and stewing. It is also valuable for medicinal purposes. A deep, rich soil is indispensable to secure large, heavy stalks. Plant in rows four feet apart, with the plants three feet distant. Set so that the crowns are about one inch below the surface. Top dress in the fall with stable manure and fork under in the spring.

MYATT'S LINNAEUS-Those who have never grown this variety which is of superior quality, will hardly recognize the old "Pie Plant." It is an early, tender variety, without being in the least tough or stringy with a mild subacid flavor. 


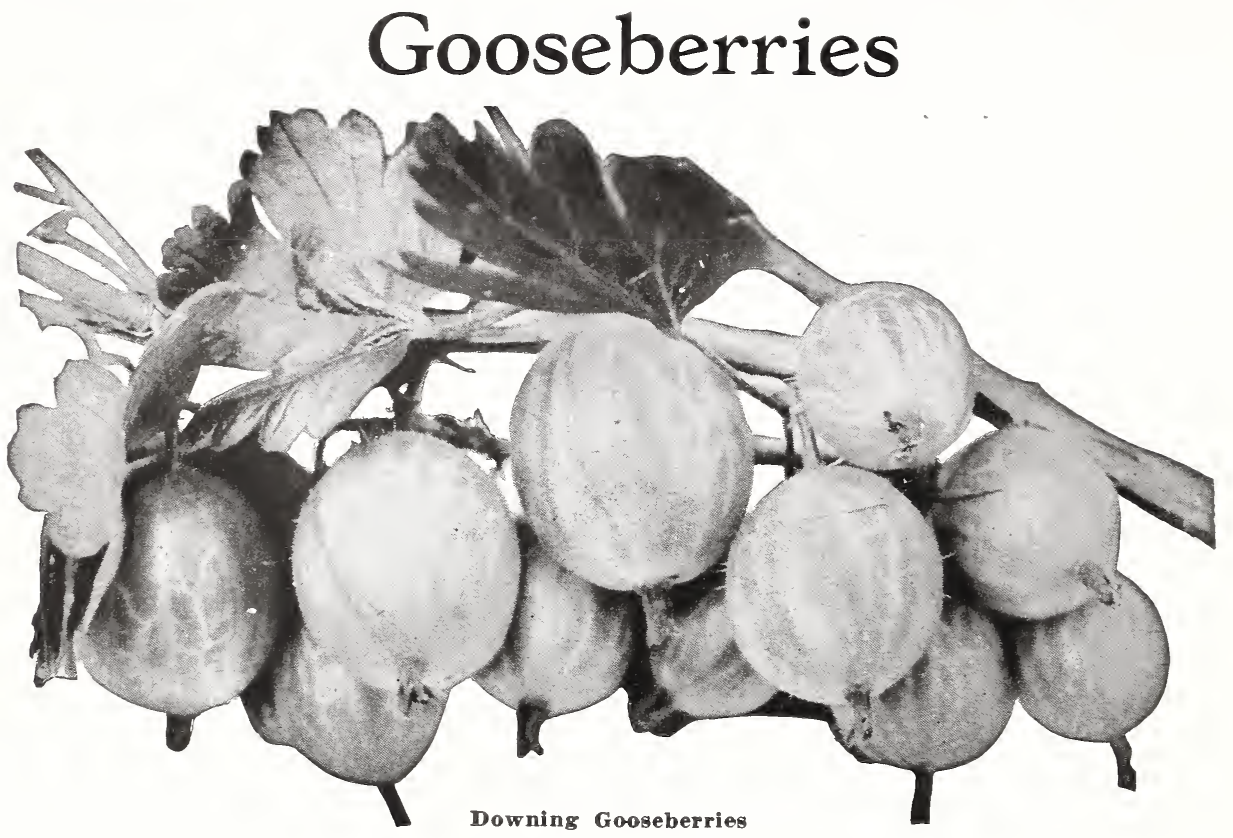

The Gooseberry requires a deep soil, well manured, and, if inclined to be dry, should be mulched to retain the moisture. The bushes should be thoroughly trimmed and pruned to obtain large, fine fruit.

DOWNING (See illustration) - Fruit large, round, light green with distinct veins, soft, juicy and fine flavored; vigorous and productive; smooth skin; one of the best.

HOUGHTON-Medium size, pale red, sweet and juicy; vigorous grower, abundant bearer and free from mildew. Considered by many the best paying sort in cultivation.

OREGON CHAMPION-Berries medium, round, smooth, greenish-white with thin transparent skin; good quality and ripens early; bush vigorously and very free from mildew.
PEARL-An exceedingly prolific variety that has been well tested and ranks No. 1 in healthfulness and productiveness. Same color as Downing; seems to possess all the good points of that variety. Valuable for home use and market.

RED JACKET (Josselyn)-Large size, smooth, prolific and hardy. Has been tested by the side of all leading varieties, is freest from mildew of all. A wonderful cropper, with large, smooth, pale red fruit of first class flavor.

\section{Asparagus}

This excellent and finest of spring vegetables is among the easiest cultivated and most profitable. A bed once planted suffers no deterioration for thirty years or more, if it is properly attended to and well manured.

See that the ground is well drained, naturally or otherwise, work it up fine and deep and make it very rich with well-rotted barnyard manure. Place the plants twelve to eighteen inches apart in rows

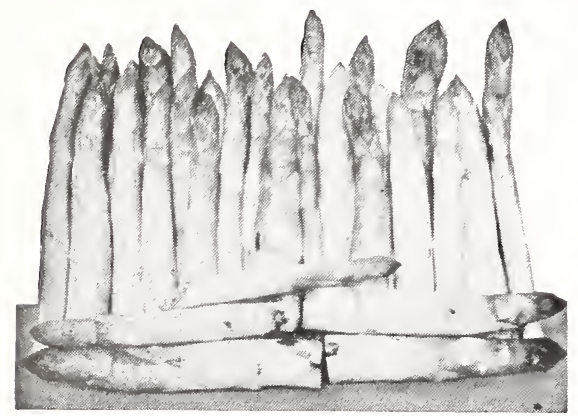

Conover's Colossal four feet apart. Spread out the roots in a trench made deep enough to permit their crowns to be covered with three or four inches of mellow earth. Give the bed liberal dressings of manure at intervals, and, except near the seashore, three pounds of salt per square yard early every spring. Do not cut for use until the second season.

CONOVER'S COLOSSAL-This variety is much superior in size and quality to any of the old common sorts, being remarkably tender and fine-flavored. The large green shoots, one to two inches in diameter, are sent up thickly from the crowns, making it a very profitable variety.

\section{NUMBER OF PLANTS TO THE ACRE}




\section{Strawberries}

Few fruits offer greater returns for land and labor invested than strawberries. With little care and attention they thrive in most any soil, while extra efforts and cultivation will be rewarded by especially fine crops. Whether you grow for market or home use only, have the best sorts by all means. Below and on the next page we list the cream of all for this part of the country.

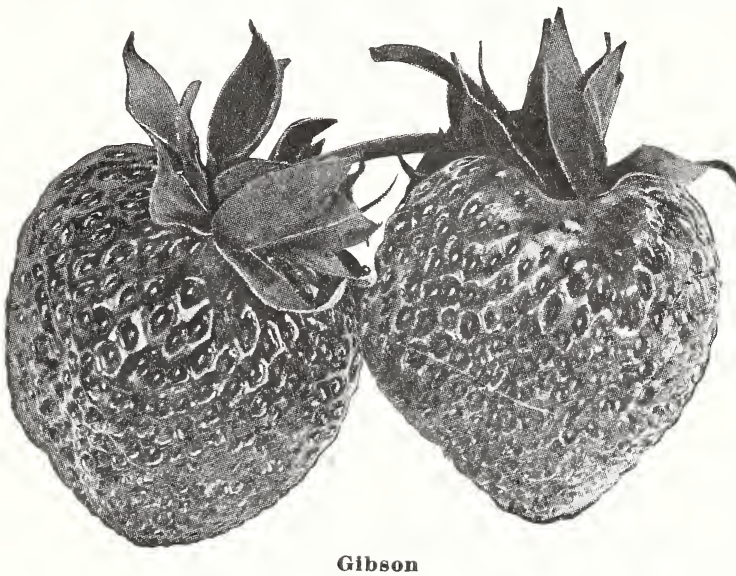

\section{CULTURE OF STRAWBERRIES}

The ground should be prepared the same as for the other crops; if not already rich, make it so by manuring. Mark out the rows the desired width and set plants twelve to seventeen inches in rows; if set twelve inches in rows four feet apart, an acre will require 10,890 plants-same as if sixteen inches in rows three feet apart. Keep in rows and cultivate. A new bed should be planted every two or three years. In the early winter, when the ground is frozen, cover the whole with long straw, which should be partially removed from the row in the spring, but enough allowed to remain on the ground as mulch to keep the berries clean the following summer. When the plants are moved in the fall, they should be left until September.

\section{Spring-bearing Varieties}

AROMA-Large, dark red; uniformly roundish, heart shaped; flesh firm and of very good qual. ity. Stands shipping well; plants vigorous and very productive; blossoms rich in pollen and is good fertilizer for imperfect varieties. Late.

CHARLES I-Probably the largest and most productive strawberry grown. Quite dark red color. A very firm fruit and for delicacy of flavor it has no equal.

DR. BURRILL-Fruit is large, beautiful, dark red in color, and of excellent flavor. Shape simi. lar to the Senator Dunlap and ripens at the same time as the Dunlap; great canning berry. It is an excellent berry for the home garden or for the market. None better.

GANDY-Large, light crimson; flesh of firm, good quality. Plants vigorous but should be planted in swamp or moist, clay soils. Perfect. Late.

GIBSON-This is the most popular strawberry extant today. Best for market and best for the home garden. Berry large; dark glossy, red, nearly round, very productive. Plant Gibson and success will be yours.

\section{Everbearing Varieties}

PROGRESSIVE EVERBEARING-The berries are not as large as Superb and not so good quality, but they yield well and, we think, will be one of the best known varieties of fall bearers in a few years. Fruit of Progressive is of good size, smooth, of good color and appearance.

SUPERB EVERBEARING-Very large, dark red and glossy; fine quality. It begins to bear in June with immense crops and continues until late in fall. It is one of the heaviest bearers of berries in June as well as a remarkable fall bearer. Will produce a fair crop of fruit the first summer.
KLONDIKE-Large; red; flesh firm, red to the core, with a mild and delicious flavor, unlike any other variety. Is very popular with south. ern growers who ship. Plant tall, compact, vigorous grower; resists frosts well and yields good crops. Perfect. Midseason.

POCOMOKE-Good variety. Hardy and productive. Berries beautiful bright red, very large and firm. Flavor good. Stands shipping well. A fine market berry.

SENATOR DUNLAP-This berry is of the Warfield type, has a perfect blossom, is hardy, productive, a splendid keeper and able to hold its own under any "rough and tumble" methods of culture to which it is likely to be subjected. It is a very heavy bearer of good size, even fruit, of a very beautiful dark red color. It is a berry to grow for either home use or market.

WARFIELD-There is probably no better or more profitable berry grown for market. It is in greater demand than any other berry for canning purposes, which also creates a good market for it. Care should be taken to use the right berries as fertilizers. It needs a strong pollenizer.

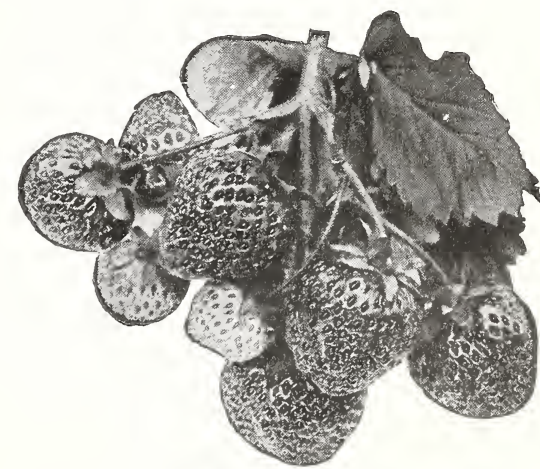

Progressive Everbearing Strawberrles 


\section{Grapes}

$\mathrm{E}$

VERYONE should have a few grape vines in the home garden. They require very little cultivation and the returns are so abundant. If proper selection of varieties is made, one may have grapes on the table for several months in the year. They can be trained over fences, trellises, or doorways and thus be ornamental as well as useful. To grow for market, they can be planted on hillsides that are unsuitable for other crops. They should in all cases have a free exposure to the sun and air.

\section{Red Varieties}

AGAWAM-Bunch large, shouldered; berry large, reddish brown, tender vinous and of excellent flavor. Very rigorous and productire. Vine hardy and one of the best of its class.

BRIGHTON-Bunch large, shouldered; berries medium to large, round, dark red, tender, rery little pulp, sweet, juicy, slightly aromatic and rery good. Ripens early.

CATAWBA-Bunches medium, shouldered; berries large, deep coppery red, becoming purple when ripe; flesh somewhat pulpy; juicy, sweet, aromatic and rich; one of the latest.

DELAWARE-The bunches are small, compact, and sometimes shouldered; berries are small with thin but firm skin; flesh juicy, rery sweet and refreshing and of the best quality for both table use and for wine. Ripens with Concord or a little before; vine is hardy, productive and a moderate grower.

SALEM-Bunch large and compact; berry large, of a light chestnut or Catawba color, thick skin, perfectly free from hard pulp; very sweet and sprightly with a most exquisite aromatic flaror; as early as Worden; keeps well.

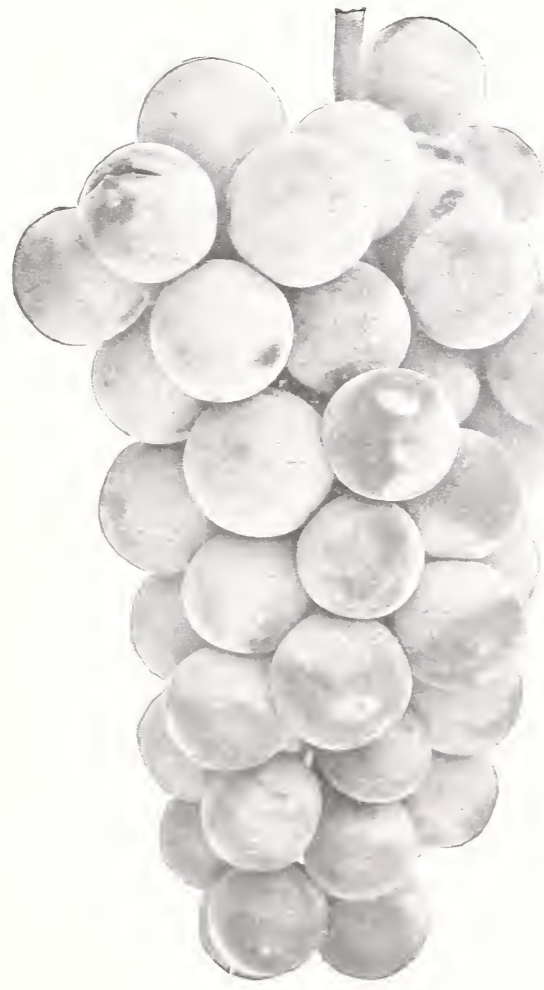

Salem

\section{The Best White Variety}

NIAGARA-Occupies the same position among the white rarieties as Concord among the black. Bunch and berries large, greenish white, changing to pale yellow when fully ripe. Skin thin but tough, quality much like the Concord.
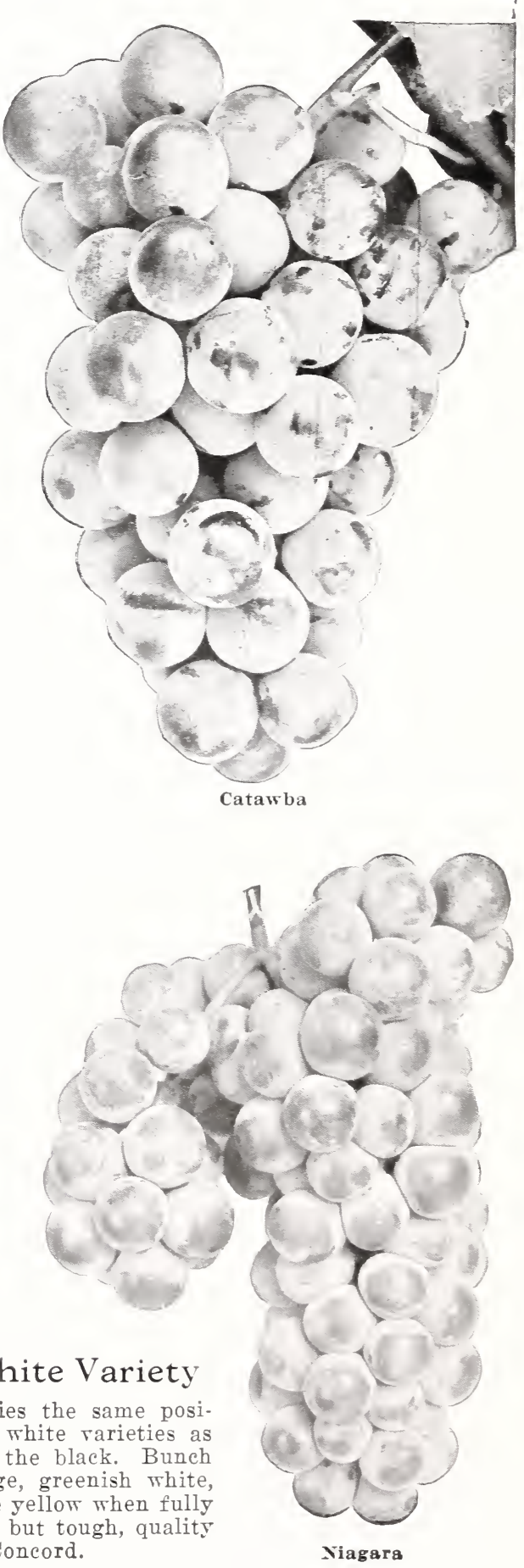

Niagara 


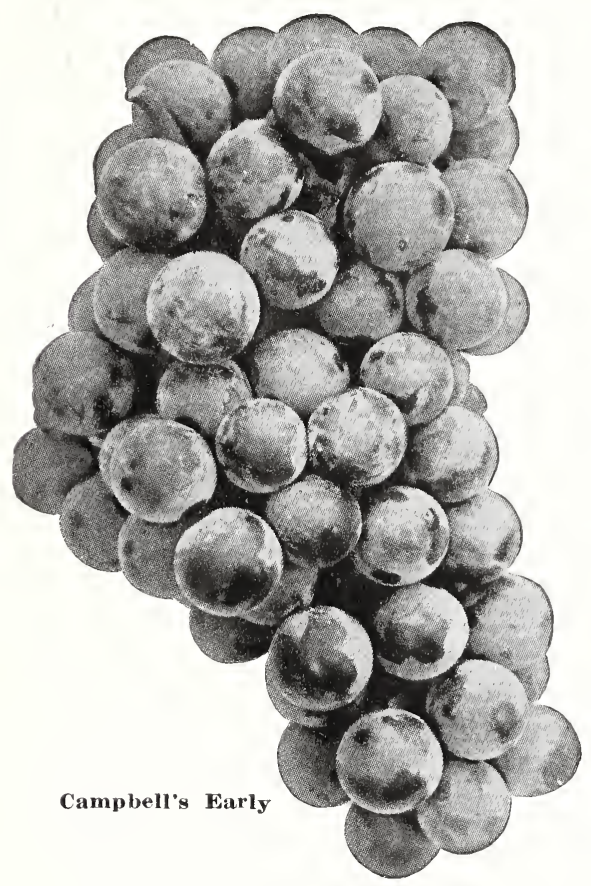

CONCORD-One of the most popular and reliable varieties we possess; bunch large, compact and shouldered; berry large, round, almost black with blue bloom, juicy, buttery and very sweet.

MOORE'S EARLY - A large grape, ripening a week earlier than Concord; good grower; berries large, good quality, and makes a moderate yield; very valuable as an early grape.
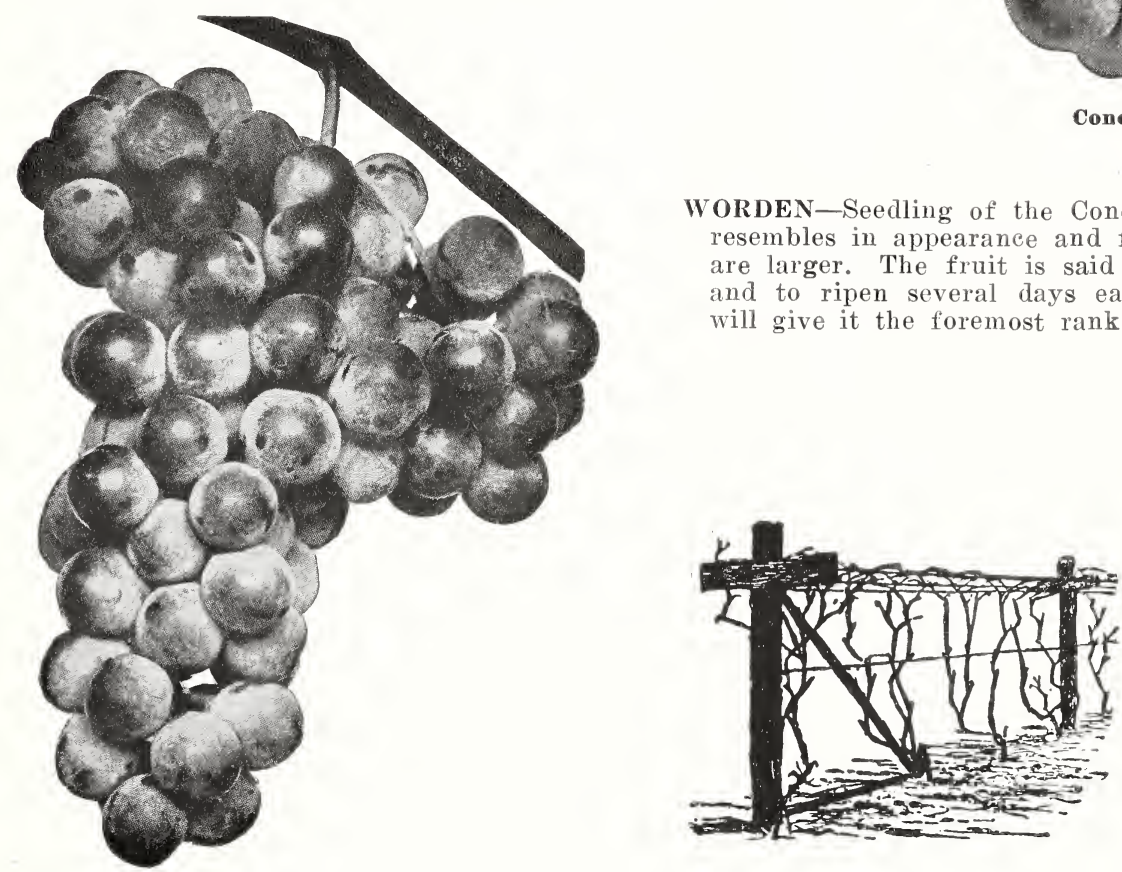

\section{Black Varieties}

CAMPBELL'S EARLY - A new, very large and fine early grape, black; strong, vigorous, hardy vine with thick, healthy leaves; clusters very large, usually shouldered, compact and handsome; berries large, nearly round, black, rich, sweet, very good; skin thin; seeds few and small, parting easily from the pulp; a good shipper. Ripens very early, but remains sound on the vines for many weeks. This makes it one of the most satisfactory and profitable market sorts to grow.

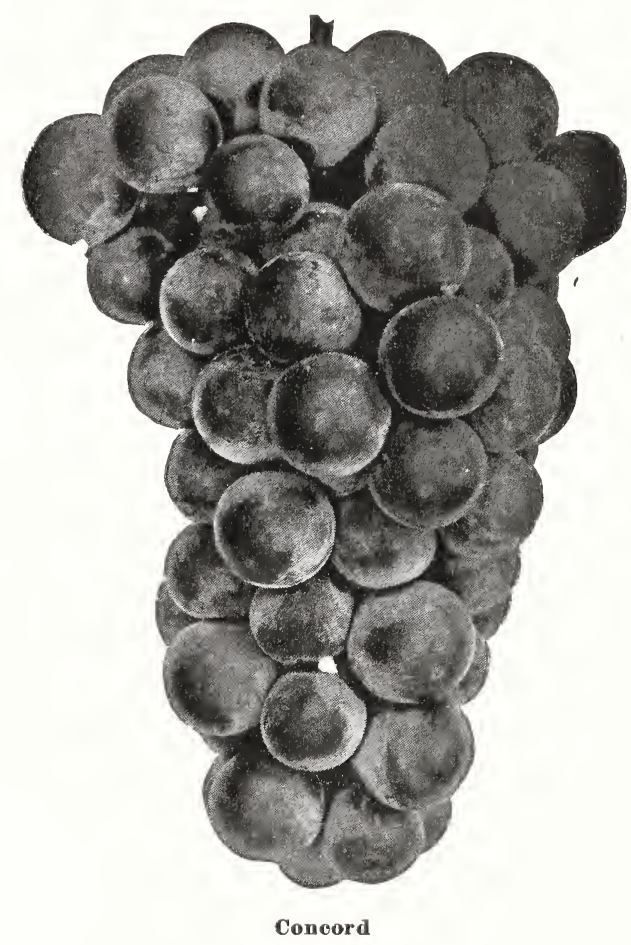

WORDEN-Seedling of the Concord, which it greatly resembles in appearance and flavor, but the berries are larger. The fruit is said to be better flavored and to ripen several days earlier. These qualities will give it the foremost rank among native grapes. 


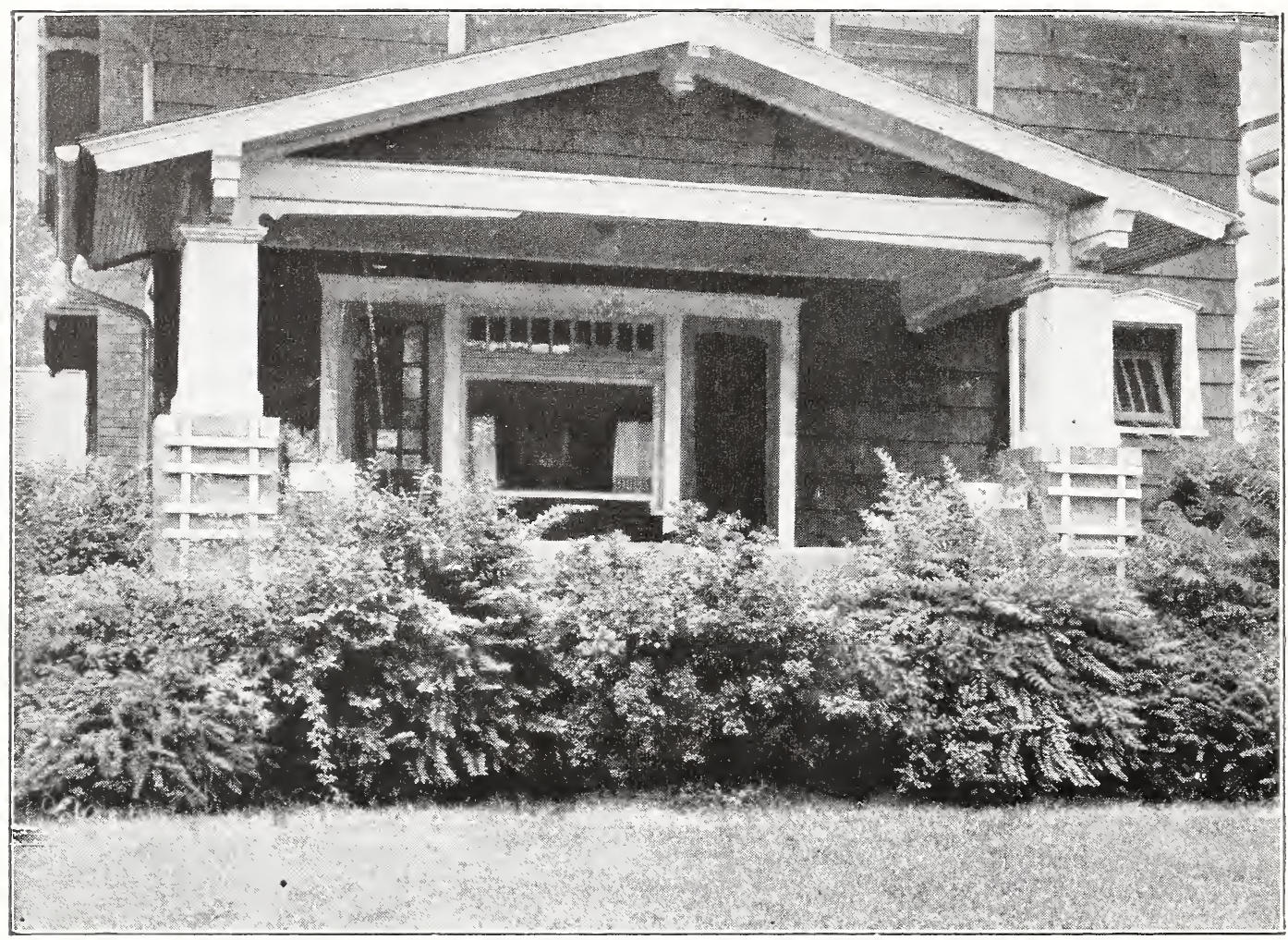

\section{Ornamental Shrubs}

$\mathbf{P}^{\mathrm{n}}$

EOPLE, generally, are appreciating more the permanent value and beauty of shrubs. The charm and grace they lend to home grounds is invaluable, and, if judicious selection is made, it is possible to have a continuous succession of bloom from early in April to the days when the frost again nips the flowers of the very latest to bloom.

In many cases it would be better to plant shrubs in groups of several to one side of the lawn instead of following the method of planting one in a certain place and spoiling the effect of the open lawn. In most cases, three, six, eight, or twelve of one variety should be used in a particular grouping. Several such groupings make an excellent border or foundation planting.

\section{Althea or Rose of Sharon}

\section{(Hibiscus Syriacus)}

The Altheas are fine, free - growing flowering ohrubs of very easy cultivation. Desirable on account of flowering in August and September, when nearly every other shrub or tree is out of bloom. They are of good size, many colored, attractive. Perfectly hardy and can be had in various colors if desired. Entirely free from all insect pests; always gives delight and satisfaction. Require pruning each spring. We can supply Altheas in the following colors: Blue, Pink, Purple, Red, White and Variegated.

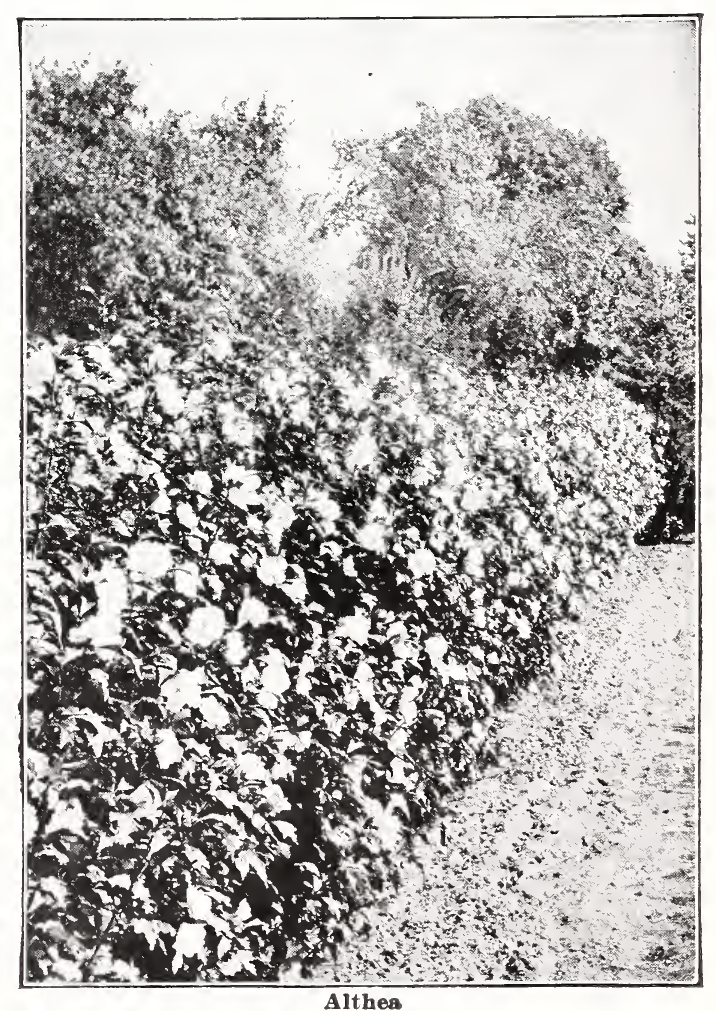

Althea 


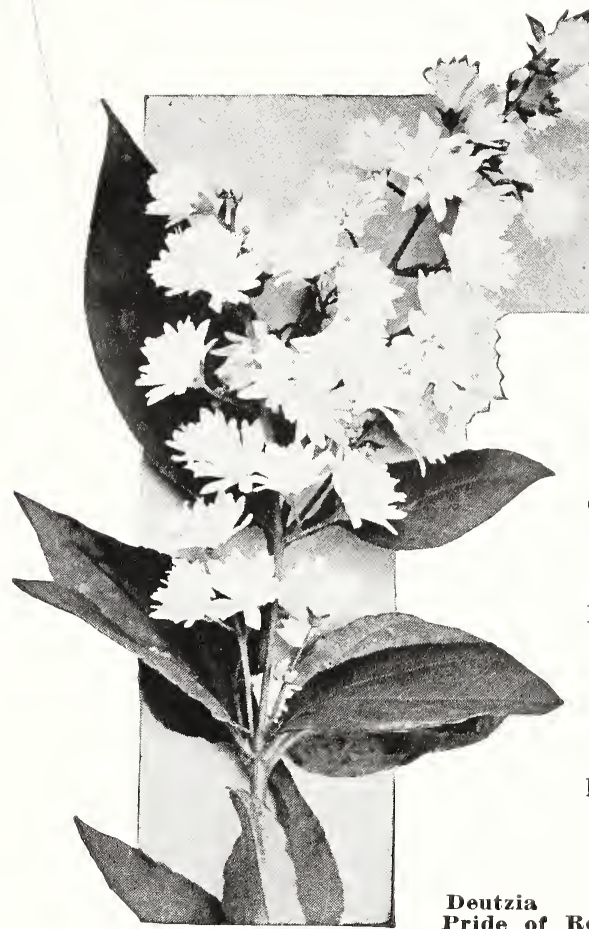

\section{Flowering Almond}

(Prunus japonica)

PINK DOUBLE FLOWERED ALMOND (P. jap. for pleno rosea)-A vigorous, beautiful tree, covered in May with rose-colored blossoms like small roses; hardy.

WHITE DOUBLE FLOWERED ALMOND (P. jap. flore pleno alba)-Same as above except blossoms are pure white.

\section{Berberis Thunbergii}

Japanese Barberry. A pretty dwarf species that will fit into almost any planting and will grow in most any place. Handsome foliage of bright green oval shaped leaves which turn to the most brilliant shades of coppery red and orange in autumn and which remain on until late fall. The slender, graceful little branches are lined with small scarlet berries which hang until well into winter and help give life to the shrubbery border, especially when there is snow on the ground. Used for foundation and group plantings and hedges. (Does not harbor wheat rust.) Height 2 to 3 feet.

\section{Calycanthus}

\section{Sweet Scented Shrub}

C. FLORIDUS-A native species with double purple flowers, very fragrant and the wood is also fragrant. Foliage rich dark green; blooms in June and at intervals afterwards. See illustration.

\section{Dogwood}

\section{Cornus Siberica}

Red-Twigged Dogwood. Good for border groupings, where the smooth, slender, bright red branches in winter make a very pleasing contrast with evergreens and snow. Small white blossoms early in summer. Good foliage. Thrives in shade. Height 6 to 8 feet.

\section{Deutzia}

CRENATA-A very hardy shrub with luxurious foliage and a profusion of double white flowers tinged with rose, produced in late June on long racemes; one of the most desirable in cultivation.

LEMOINE (D Lemoinei) - The flowers are pure white; shrub dwarf and free flowering; exeellent for forcing.

PRIDE OF ROCHESTER-Produces large white flowers, tinged with rose; vigorous growers, profuse bloomer and one of the earliest to bloom.

GRACILIS (Slender Branched Deutzia)-Of dwarf abit; flowers pure white; one of the first to bloom; fine or pot culture and winter blooming.

\section{Elder-Sambucus}

ELDER (S. canadensis) - A large, showy shrub, n in June; flowers white, borne in large panicles; fruit eddish-purple berries in the fall.

GOLDEN (Sambucus nigra aurea) - A handsome rub, with golden yellow foliage and clusters of pure white ters. Excellent for lawn planting.

\section{Forsythia}

Golden Bell

E'S FORSYTHIA (F. Fortunei)-A beautiful shrub reen; the best of the early flowering shrubs.

\section{Upright Honeysuckle (Lonicera)}

PINK TARTARIAN HONEYSUCKLE (L. Tartarica rosea)-Pink flowers that make a lovely contrast with the foliage; planted with the Grandiflora, the two make a beautiful display.

RED TARTARIAN HONEYSUCKLE (L. T. vaTrubra)-Blooms early in the spring; flowers a beautiful bright red.

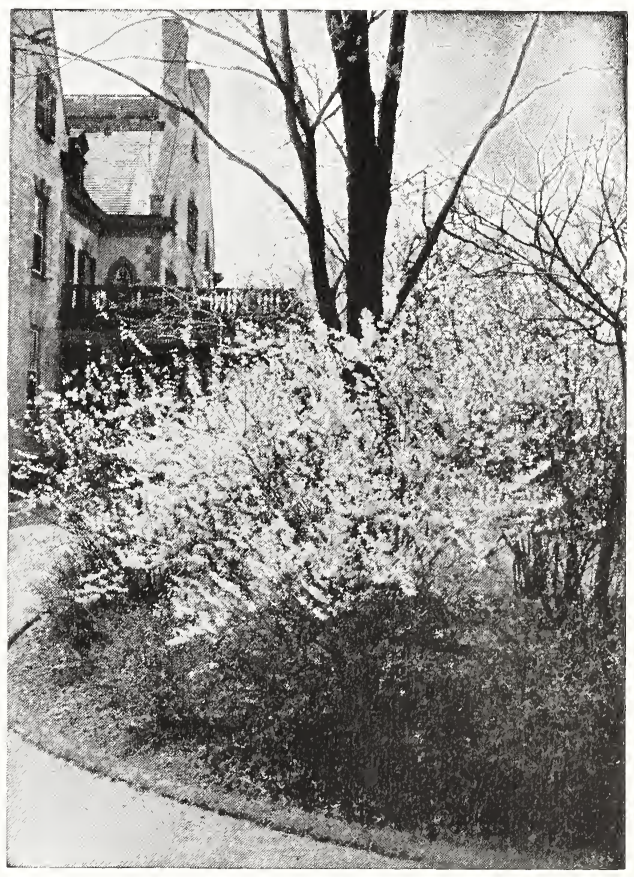

Forsythia-Golden Bell 
Upright Honeysuckle-(Continued)

WHITE T A R T A I A N HONEY. SUCKLE (L. T. var. Alba)-Produces creamy white, fragrant flowers in May and June; forms a high bush.

\section{Hydrangea Arborescens Sterilis (Hills of Snow)}

This grand American shrub deserves increased attention. Handsome foliage and showy, snow white, ballshaped clusters of flowers make it a most conspicuous object wherever grown. Blooms the greater part of summer, does its best under all eircumstances, is perfectly hardy and increases in size and beauty from year to year. Does best in moist, fertile soil with full exposure to the sun. Thrives most anywhere and does well even if neglected.

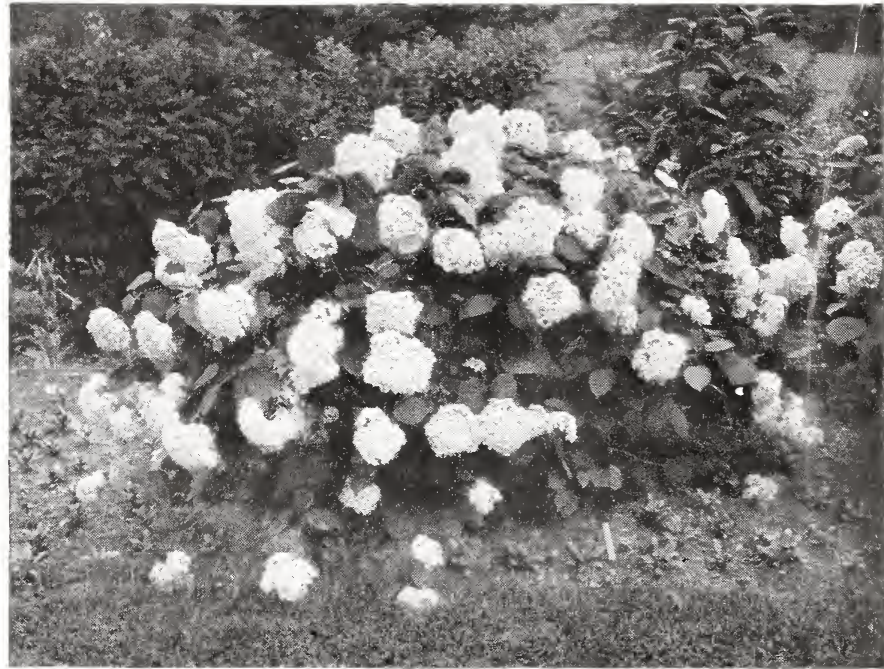

Hydrangea Arborescens Sterille

\section{Hydrangea, P. G.}

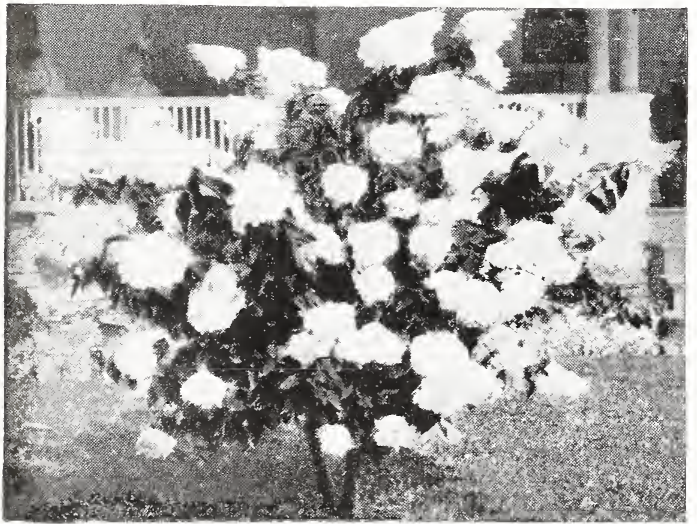

Hydrangea Paniculata Grandiflora

\section{Lilacs}

The lilacs are well-known, beautiful shrubs, indispensable in every collection.

CHARLES THE TENTH-A strong growing bush producing loose trusses of reddish purple flowers which fade to mauve.

FRAU BERTHA DAMMANN-Single; large panicles of pure white flowers. Very fine variety.

LUDWIG SPAETH-One of the darkest shades, very dark crimson-purple. Single.

PERSIAN LILAC (S. Persica)-Grows 4 to 6 feet high, foliage small and flowers a bright purple.

PRESIDENT GREVY-Double. Clusters large, full; pale wisteria-violet.

PURPLE LILAC (S. Vulgaris)-The well-known purple variety; always a standard sort.

VILLOSA-Late blooming lilac. Flowers large, light purple in bud, white when open, fragrant. Does not grow high. Height 5 to 8 feet.

WHITE LILAC (S. Vulgaris Alba) - Too wellknown to need description; flowers white and fragrant.
PANICULATA GRANDIFLORA-A beautiful, tall shrub with leaves of bright, shiny green; flowers borne in huge panicles from 8 to 12 inches long, light pink, changing to brown later in the fall; blooms in August and September; can be grown in tree form successfully and makes a very desirable lawn ornament. See illustration on preceding page.

\section{Japan Quince}

SCARLET JAPAN QUINCE (C. Japonica, also Pyrus japonica)-One of the best flowering shrubs; flowers a bright scarlet erimson, borne in great profusion in early spring; foliage retains its color of bright glossy green the entire summer; hardy; make good hedge plants.

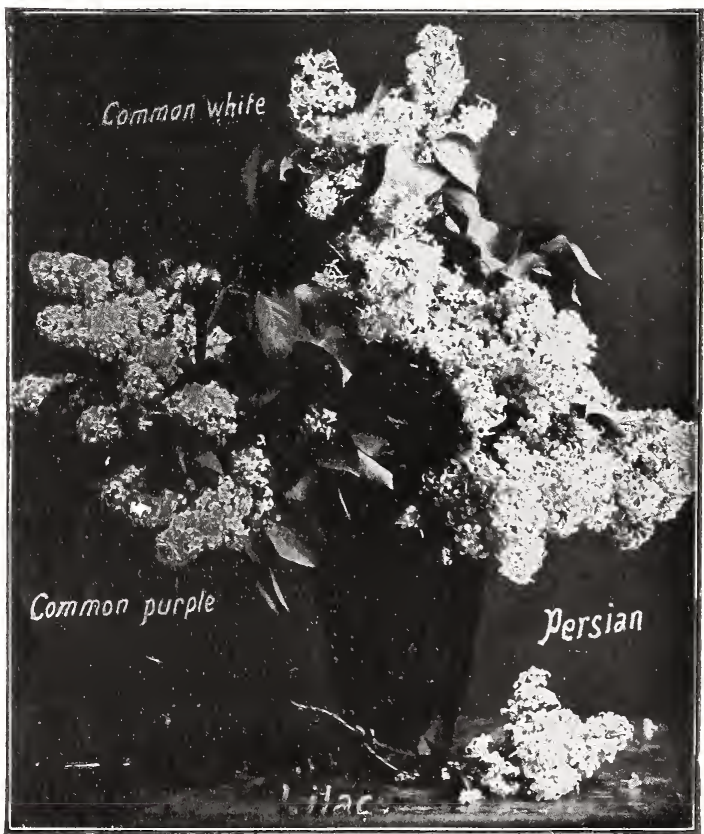

Llace 


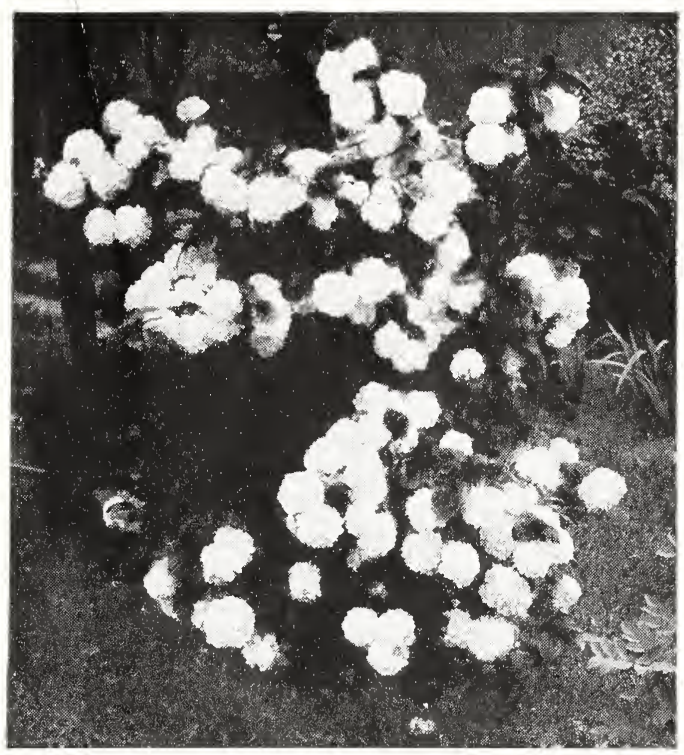

\section{REGEL PRIVET}

(L. Ibota Regelianum)

A form of Ibota Privet, with spreading, horizontal branches. Very picturesque when planted as single specimens or in shrub groups and many persons prefer it for use in hedges on account of its attractive foliage, graceful habit and hardiness.

\section{RUSSIAN OLIVE}

\section{Elaeagnus Angustifolia}

While this plant really is a small tree, yet when it is kept pruned rather severely, it forms a most attractive shrub. Its foliage is of a remarkable silvery hue, showing up in striking contrast to that of the green of other shrubs or trees. It is admirable for tall backgrounds where unusual color tones are desired. It also is useful for hedges, either trimmed or untrimmed.

\section{SNOWBALL}

\section{Viburnum}

COMMON SNOWBALL (V. Opulus Sterilis) Grows 6 to 8 feet high, the old fashioned snowball; its large globular clusters of pure white flowers are produced in May and June and makes a very attractive appearance.

JAPAN SNOWBALL (V. Plicatum)-Foliage a handsome olive-green; flowers are larger and more white than the Common Snowball; borne in dense heads; very ornamental.

\section{SNOWBERRY}

Symphoricarpus

CORAL BERRY (S. Vulgaris)-A slender branched upright shrub, valuable for planting in shady places, as the foliage is very persistent; the fruit is purplish red and hangs on well into winter; flowers small and rose colored.

SNOWBERRY-WAXBERRY (S. Racemosus)Same as the above except the berries are a pure, snow white; flowers rose colored, but larger.

\section{SPIREA-The Spireas}

This group of shrubs affords the greatest range in size, habit and color of flowers of any commonly c u l t i v a t e d ornamentals. Spireas are of great beauty when in bloom and of large value for a great variety of decorative purposes.

S. CAllosa ALBA-An up. right shrub, becoming 18 inches to 2 feet high. Very profuse bloomer, and continuing in flower throughvut the summer. Flowers pure white, in flat topped clusters.

S. THUNBERGI (Thunberg Spirea)-A very graceful, early flowering shrub, the slender branches clothed with feathery, b r i g h t green foliage. Flowers pure white in early spring.

ANTHONY W A T E RER SPIREA-A very popular low growing bush, becoming 2 feet high and constantly in bloom all summer. Flower clusters large, flat topped and of deep rose color.

BILLARD SPIREA (S. Billardi)-Tall, erect shrub with canes terminated by feathery plumes 5 to 8 inches long, of dainty pink color.

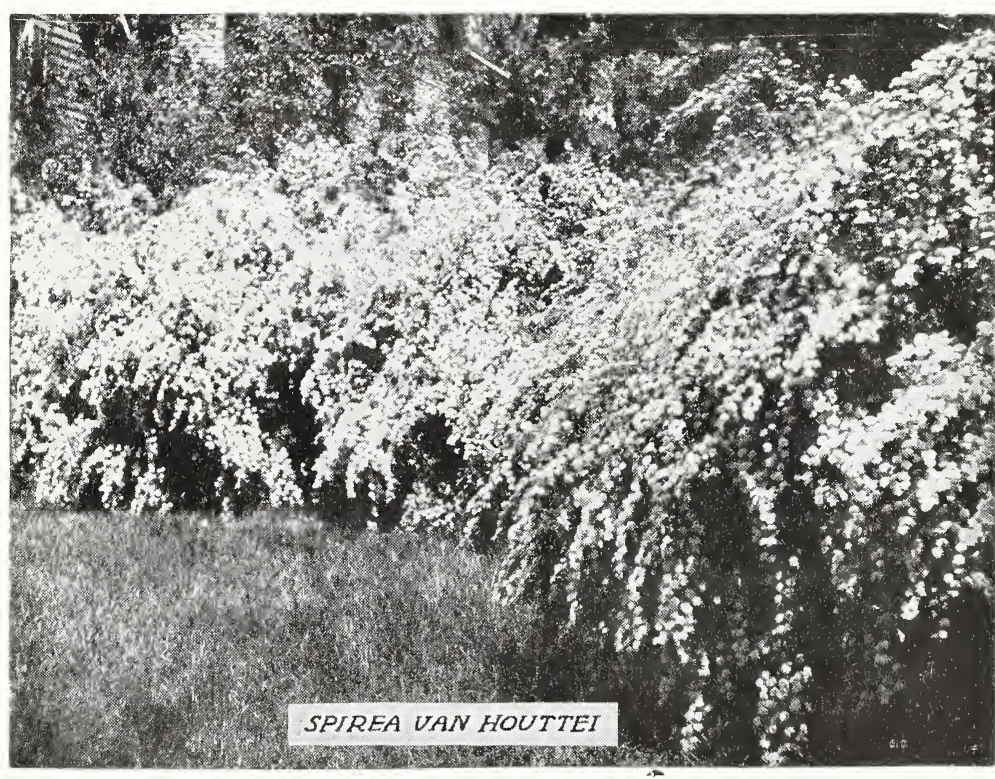

VAN HOUTTE SPIREA (S. Van Houttei)-This is the most popular of all the spireas, and is more largely planted than any other one shrub. Its gracefully arching branches heaped as they are with the white blossoms in spring, and its thriftiness under the most trying of conditions, are the reasons for its popularity. It is adapted to many purposes in out-door decoration and wherever it is put it thrives, always giving beauty and cheer in return. 


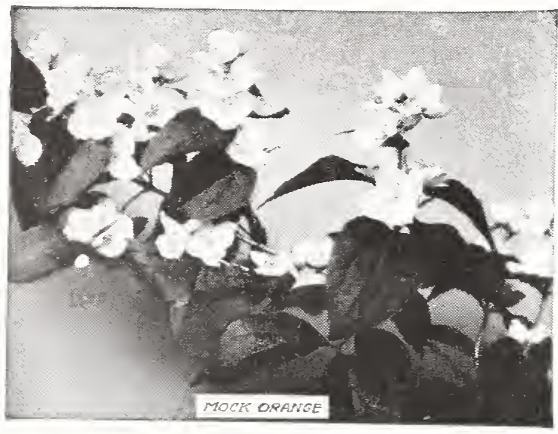

TAMARIX

T. AFRICANA-A beautiful shrub with small leaves; similar to the Juniper; flowers are pink, small and delicate, borne on long spikes; blooms in May.

\section{WEIGELA}

\section{Diervilla}

The Weigelas are shrubs of erect habit while young, but gradually spread and droop as they acquire age; flowers are large, trumpet-shaped, of all shades and colors; very effective for grouping and borders; blossoms are produced in June and July.

CANDIDA-Flowers pure white produced in June and continue to bloom nearly all summer.

EVA RATHKE-Flowers a brilliant crimson; a beautiful clear, distinct shade.

ROSEA-An elegant variety with fine rose colored flowers appearing in June.

VARIEGATED (Nana variegata)-This is perhaps second to no other hard-wooded plant with variously colored leaves. It stands the sun well and retains its well marked tints until Autumn. The flowers are lighter in color than the Rosea, but it is equally as free in bloom.

\section{SYRINGA OR MOCK ORANGE}

\section{Philadelphus}

GARLAND SYRINGA (P. Coronarius)-A well-known shrub bloom.

LEAVED SYRINGA (P Coronarius, var Aurea)-A variety with golden-yellow foliage; keeps its 列 varieties for pleasing effects.

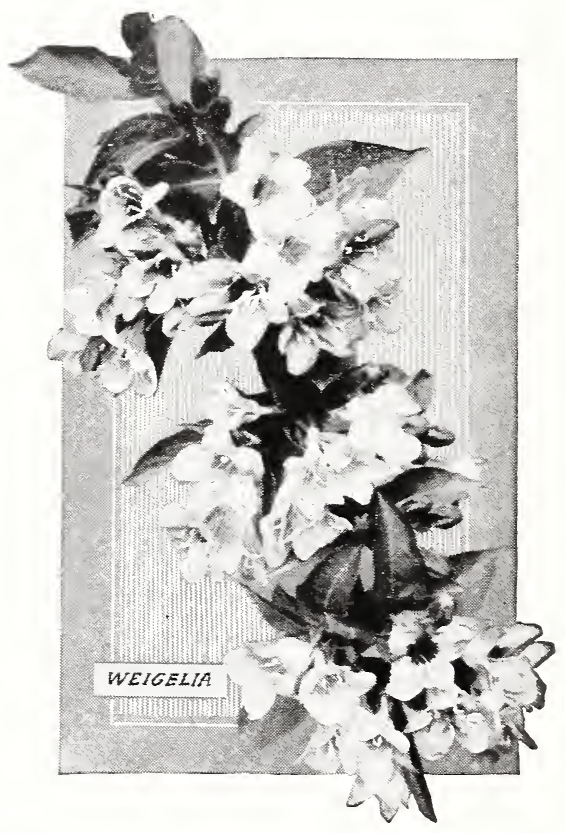

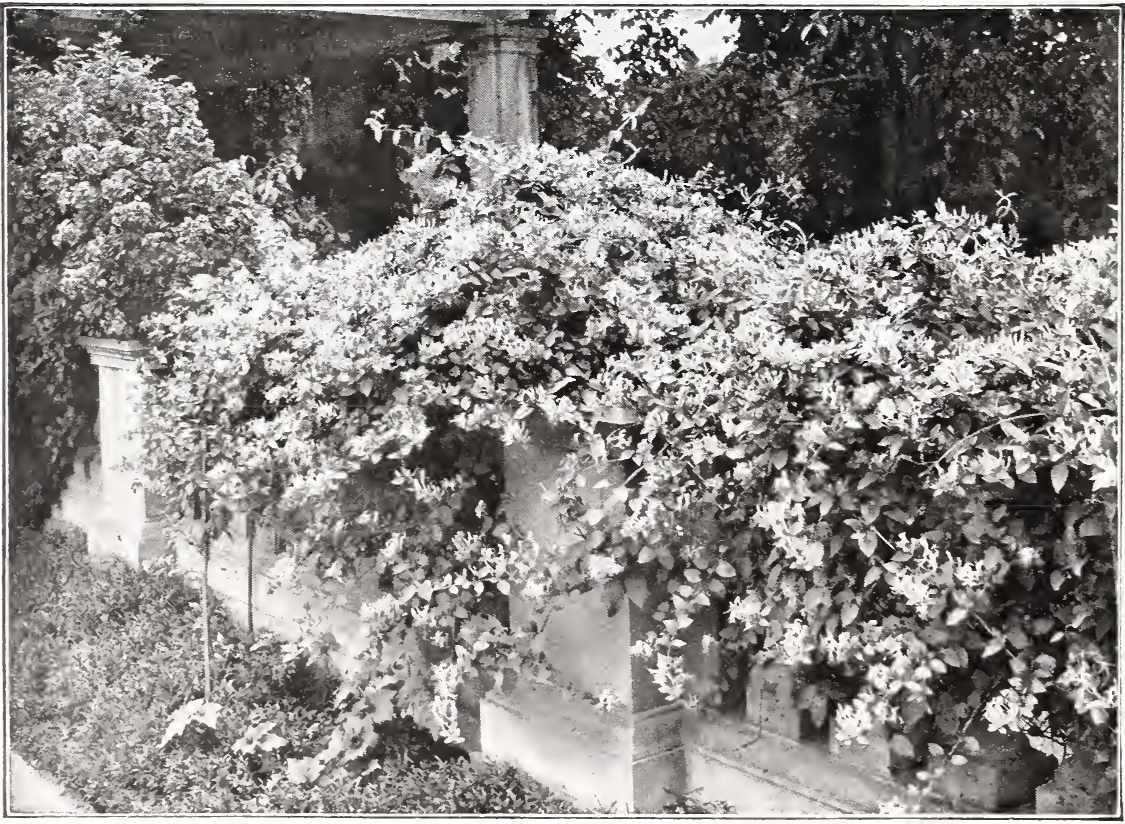

Honeysuckle, Hall's Japan 


\section{Hardy Climbing Vines}

Vines are useful in many ways. They give quick results when planted on a new place, before tree and shrubs become established. For covering fences, rocks, walls, banks and trellises, they are peculiarly adapted. A porch without a vine is desolate and incomplete.

\section{ARISTOLOCHIA-Dutchman's Pipe}

SIPHO (Birthwort)-A native species of climbing habit and rapid growth, with very large, heartshaped leaves and curious pipe-shaped yellowish brown flowers.

\section{AMPELOPSIS}

QUINQUEFOLIA (American Ivy or Virginia Creeper)-A very rapid growing vine covered with heavy digitate leaves affording shade and of great beauty when changing to searlet in Autumn.

VEITCHI (Boston or Japan Ivy)-The now famous Japan or Boston Ivy used so extensively to cover brick or stone buildings. The foliage is dense, completely carpeting a surface, and the autumnal tints of green and red are unsurpassed for beauty.

\section{BIGNONIA RADICANS-Trumpet Creeper}

A high climbing, vigorous vine, native to the middle west and south. Leaves compound, produced on stout, spreading branches. Flowers in large, terminal clusters, trumpet shaped, 3 inches long. Loved by humming birds.

\section{BITTERSWEET-Celestrus Scandens}

A native climber, with handsome, glossy foliage and large clusters of beautiful orange-crimson fruits, retained all Winter. Very bright in effect and charming for Winter house decoration.

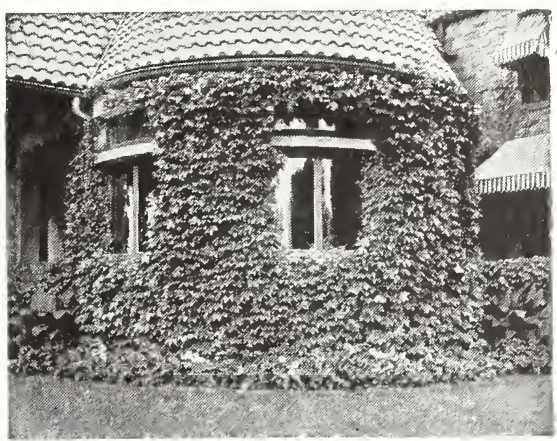

Boston Ivy

\section{CLEMATIS}

of all the vines used for either shade or decoration, none can compare with the Clematis in its many and various forms. As a climber for the veranda, a screen for fences, for pillars, along garden walks, for training on walls or arbors, in masses or rockwork, it has no rival among the strong growing. blossoming plants. Their delight is in rich soil and a sunny situation, and they are perfectly hardy. They should be well mulched with rotten manure in Winter.

\section{Large-Flowering Clematis}

HENRYI-Flowers creamy-white and very large; a fine bloomer.

JACKMANI-This variety is better known than any other, and still stands as one of the best. It is a strong grower, and produces a mass of intense violet-purple flowers four to six inches in diameter, from July until October.

MADAM EDOUARD ANDRE-Flowers are a beautiful shade of crimson; a free bloomer.

\section{Small-Flowering Clematis}

PANICULATA-A great novelty from Japan. This variety of Clematis has proved to be one of the most desirable, useful and beautiful of hardy garden vines, a luxuriant grower, profuse bloomer, and possessing fine foliage.

\section{HONEYSUCKLE-Lonicera}

HALL'S JAPAN HONEYSUCKLE (L. Halleana)-A strong, vigorous vine with pure white flowers, changing to yellow; foliage remains green well into winter; very frag. rant and covered with flowers almost the entire season; one of the best bloomers.

MONTHLY FRAGRANT HONEYSUCKLE (L. Pericly. menum, var Belgica)-Blooms all summer; flowers red and yellow and very fragrant.

SCARLET TRUMPET HONEYSUCKLE (L. Sempervirens) -One of the handsomest in cultivation; a strong, rapid grower; flowers a bright scarlet, not much odor.

\section{WISTARIA}

CHINESE PURPLE WISTARIA (W. Sinensis)-One of the best of the Wistarias; rapid growing and elegant, attaining 15 to 20 feet in a season; flowers a pale-blue, borne in long pendulous clusters in May and June.

CHINESE WHITE WISTARIA (W. Sinensis, Var Alba)Same as the Chinese Purple, except the flowers are pure white; very beautiful variety. 


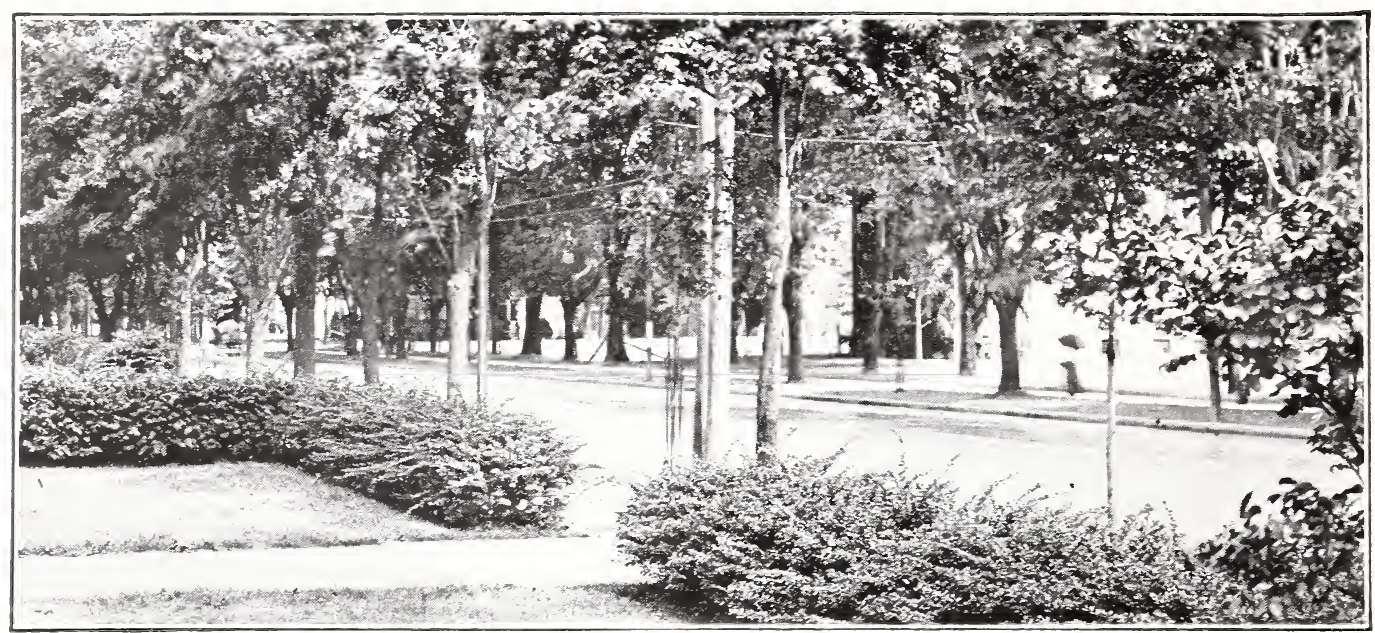

Barberry Hedge

\section{Ornamental Hedges}

An ornamental hedge speaks for itself. It frames the lawn and gives it a background. On the smaller grounds the low hedges are used, while for larger grounds and for screening purposes, the larger growing kinds are used. In most cases they should be planted one foot apart.

\section{JAPANESE BARBERRY HEDGE}

(Berberis Thunbergii) Used extensively where a good, dwarf, bushy hedge is desired. The foliage is an excellent green which turns to a beautiful coppery red in the fall, followed by pretty red berries. It is not susceptible to wheat rust. Can be grown either trimmed or untrimmed, with a height of from $1 \frac{1}{2}$ to 3 feet.

\section{PRIVET-Ligustrum}

The Best Live Fence

For neatly trimmed formal hedges about the lawn, no shrubs are more popular than the Priv. ets. The varieties we grow are ideal hedge

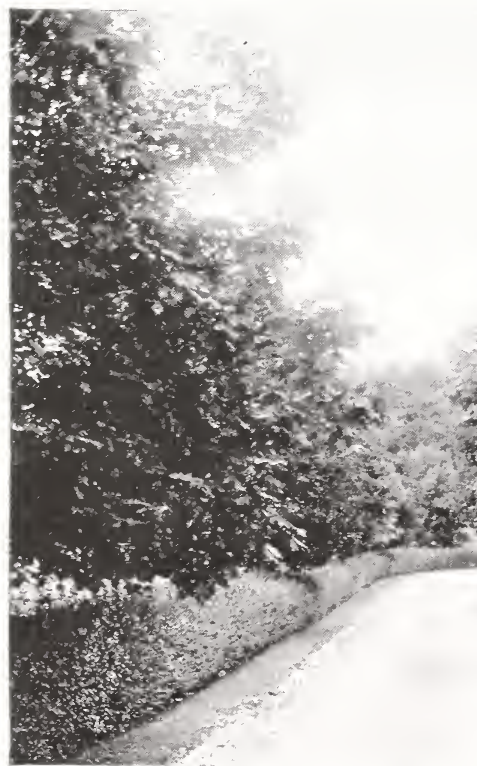

plants. They withstand frequent shearing, and the more often they are trimmed, the better they look. Every lawn should have its boundaries marked by a row of Pricet, neatly trimmed. Ideal for screening objectionable views, as when left untrimmed they become as much as 10 feet tall, very dense, and with excellent foliage.

\section{CALIFORNIA PRIVET}

\section{(L. Ovalifolium)}

California Privet, will give you living fences for less than you can build them of wire. A wire or other fence needs constant attention and will last only a limited number of years-a California Pricet fence increases in size, strength and ef. fectiveness year after year. Fences of this kind add a wonderful touch of beauty to the home grounds and they can be sheared into any shape or size or allowed to grow naturally, making a highly ornamental border to the grounds or division between fields. A few dollars invested in California Privet will add many times their value to your property, besides making it more beautiful. Plant California Privet grown by us and you will soon realize that live fences are best.

\section{AMOOR RIVER PRIVET}

(L. Amurense)

A valuable ornamental shrub for hedges and borders; very hardy; foliage glossy green and holds its color almost the entire year; will stand shearing to any extent. 


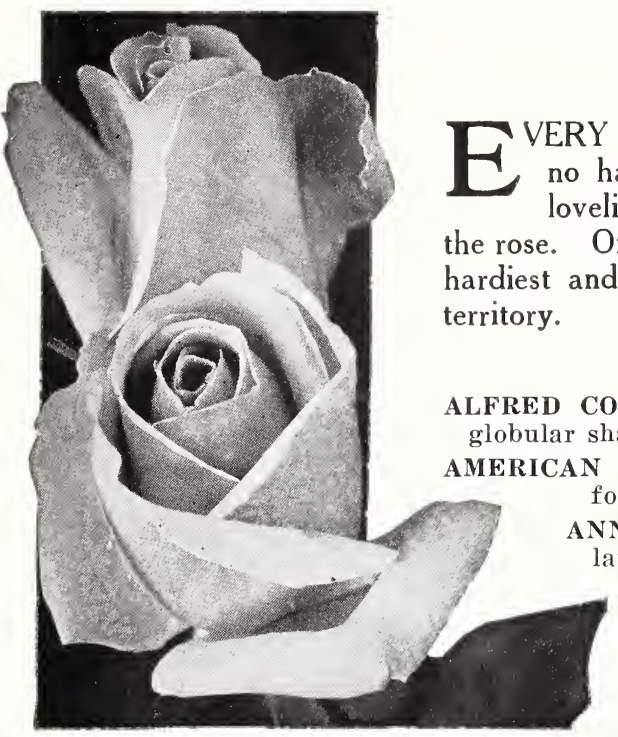

Frau Karl Druschki

\section{Roses}

ERY home should have an abundance of roses, for there is no hardy plant that produces such a profusion of genuine loveliness and rewards the grower more liberally than does the rose. Of the hundreds of varieties, the kinds that we list are the hardiest and most vigorous, as well as the best bloomers for this

\section{HYBRID PERPETUAL ROSES}

DOLOMB-Brilliant carmine-crimson; very large, full and globular shaped; very fragrant and a superb rose. form and fragrance, and large size.

ANNE De DIESBACH-Beautiful shade of carmine; very large and fragrant; quite hardy and a good foreing rose.

CLIO-One of the best; large, fine, globular form, flesh color, shading to rose in center; very vigorous.

EARL OF DUFFERIN-A beautiful velvety crimson shaded with rich maroon. Large, full flowers of delightful fragrance.

FISHER HOLMES-Of elegant form and good substance, the deep velvety erimson flowers with their brilliant scarlet centers delight the eye of every rose lover.

GENERAL JACQUEMINOT-One of the most popular of the red roses; brilliant erimson, large and very effective, very fragrant and one of the hardiest.

FRAU KARL DRUSCHKI (Snow Queen)-Pure paper-white, large and free flowering. A very handsome plant, with bright, heavy foliage and strong upright growth. The bloom is of perfect form, on fine long stems. The finest rose in color, form and general finish. If after each blooming period the branches are cut back, Frau Karl Druschki will bloom continuously throughout the season.

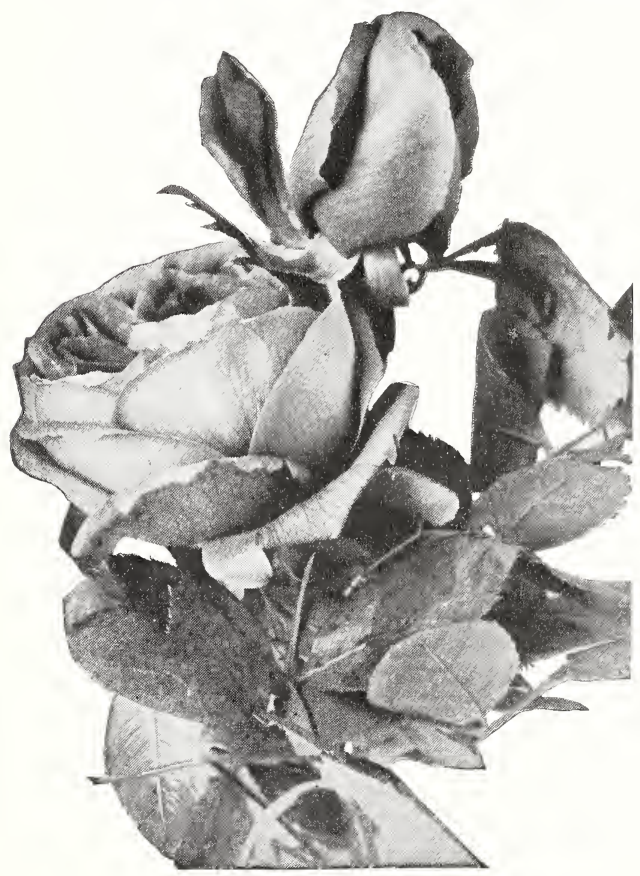

American Beauty

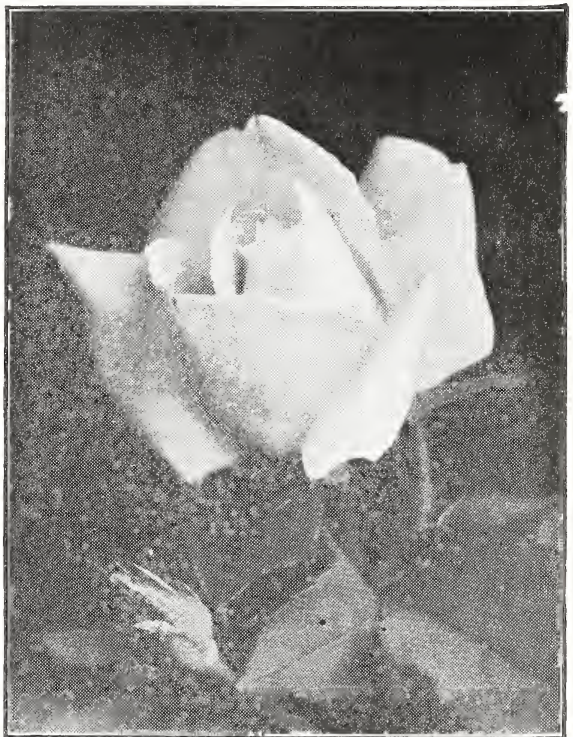

Kaiserin Augusta Victoria

(Description on page 30 )

MARSHALL P. WILDER-Extra large, full deep red; a free bloomer and very handsome.

MRS. JOHN LAING-Soft pink, beautiful form, exceedingly fragrant, and very free flowering.

PAUL NEYRON-Said to be the largest rose in cultivation; bright, elear pink, very fragrant.

PRINCE CAMILLE de ROHAN-Very dark, velvety erimson, almost black, large and full.

SOLIEL d'Or (Sun of Gold)-A strong, hardy rose; large, full and double; golden orange-yellow ting. ed with red and rosy-pink; a magnificent rose.

ULRICH BRUNNER-Rich crimson-scarlet, highly perfumed, vigorous and hardy; a very desirable sort. Price, all varieties, strong, field-grown. 


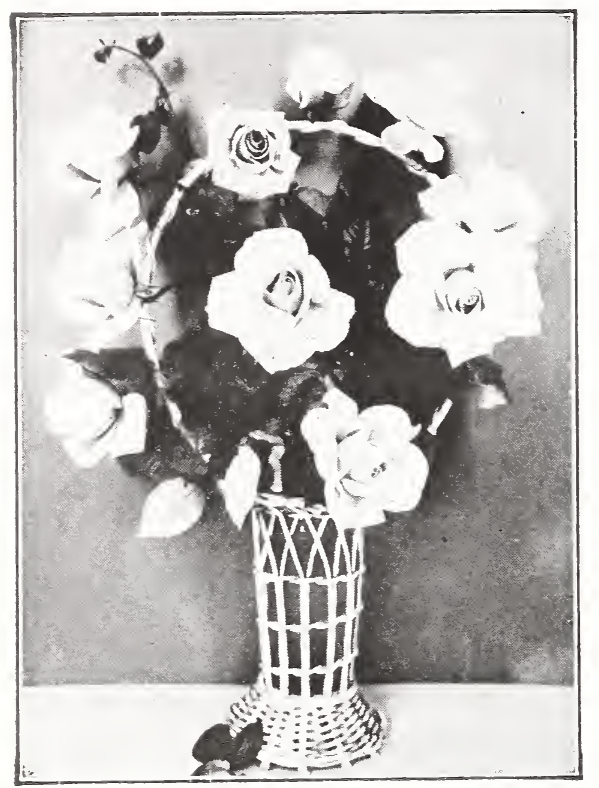

Killarney

\section{Everblooming Hybrid Tea Roses}

GENERAL MACARTHUR-For years this Rose has been one of the foremost of the red Hybrid Teas for bedding. It is a most continuous bloomer, keeping up an array of brilliant glowing crimson-scarlet flowers from early in May until frost comes. It is deliciously scented and the blooms come on long stems, suitable for cutting. A fav. orite wherever grown, as it produces perfect blooms and does well, even during the hot months of summer.

GRUSS AN TEPLITZ-Dark rich crimson, passing to velvety fiery red. An exceptionally free bloomer and one of the brightest colored red Roses grown. The canes are strong and vigorous, producing blooms constantly from June till frost. An almost continuous bloomer.

JONKHEER J. L. MOCK-The color is carmine on the outside, and imperial pink on the inside of the flower. The blooms are very large, perfectly formed, and highly perfumed. Plant an entire Rose-bed of this one kind. Very satisfactory for bedding.

KAISERIN AUGUSTA VICTORIA-This is one of the most beautiful Roses grown. Its extra-large, exquisitely formed flowers are borne singly on strong upright stems, making it very popular as a cut flower. Buds are long and the flowers very full, deep, and sweetscented. Color, soft white, slightly tinged lemon-yellow.

KILLARNEY-Flowers intensely fragrant. The buds are large, long, and pointed. Color is exquisite-a brilliant imperial pink. A bed of these beauties in full bloom is a sight not easily forgotten. An ideal Rose for eutting.

LADY HILLINGDON-Makes exquisite buds of deep apricot-yellow, shading to orange. A perfectly formed flower, free blooming and a Rose everyone admires as it comes on long stems, suitable for cutting for vases, and it is delightfully fragrant.

LA FRANCE-Both buds and flowers are of lovely form, grand size, and very highly perfumed. Color peachblossom-pink, clouded with rosy flesh. This delightful old-fashioned variety is constantly in demand.

LOS ANGELES-Produces a continuous succession of longstemmed flowers of a luminous flame-pink, toned with coral and shaded with translucent gold at the base of petals; in richness of fragrance it equals in intensity the finest Marechal Niel. The buds are long and pointed.

MRS. AARON WARD-Fine Indian yellow, sometimes washed with salmon-rose. Flowers are full double and as attractive when full blown as in the bud state. The young foliage is a rich bronzy green. This Rose will probably produce more blooms for you than any other yellow H. T.

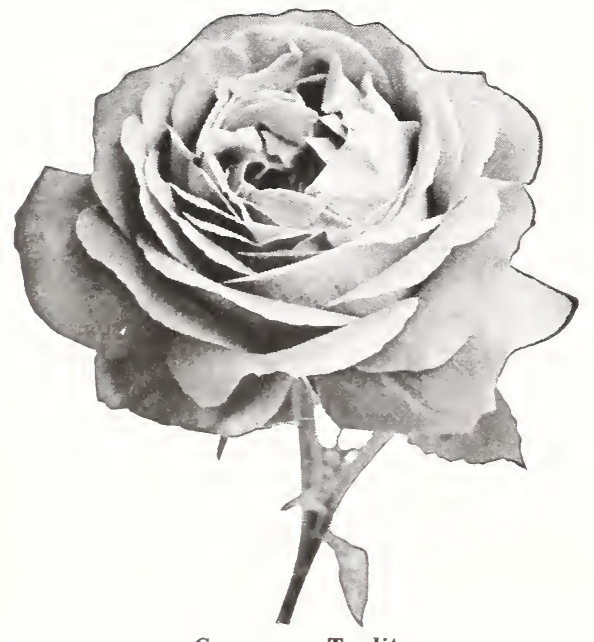

Gruss an Teplitz

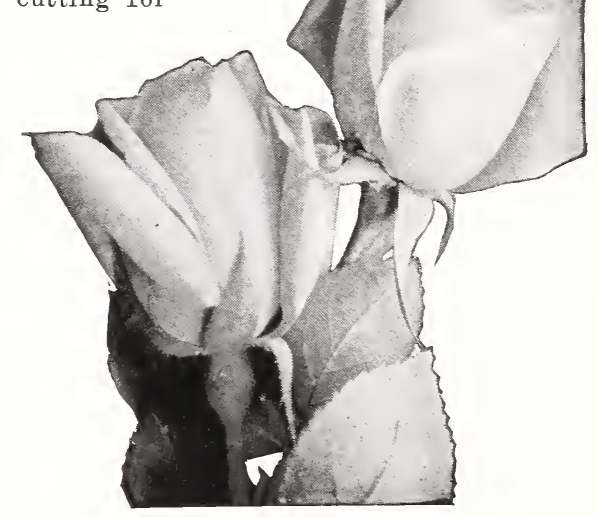

Ophelia
MME. CAROLINE TESTOUT-Large, full flowers and handsome buds. Color is clear, rich pink, finely edged with silvery rose. Fine for mass planting.

OPHELIA-Salmon-flesh color, shaded with rose. A splendid outdoor variety and one that should be planted freely for cutting as it blooms continuously. The color varies with the seasons and at times shades of soft yellow appear at the base of the petals, lending a peculiar richness to the flowers that is greatly admired.

RADIANCE-Extra hardy, vigorous and prolific; one of the best all-round garden roses. Its color is a beautiful blending of carmine-rose with shades of opal and copper.

RED RADIANCE-The wonderful, globular, heavy-stemmed "Radiance" duplicated in all respects except color; this sport form being a brilliant crimson.

SUNBURST-Color a rich cadmium-yellow, with orangeyellow center. A magnificent free-blooming variety, especially handsome in bud form. A vigorous grower with flowers of elongated cup shape. The plant is rather spreading in habit of growth and has few thorns. One of the most reliable yellows for cutting. 


\section{The Best Climbing Roses}

CLIMBING AMERICAN BEAUTY-Rich red, fragrant. Very vigorous in growth and a prolific bloomer, having hundreds of perfect flowers open at one time.

CRIMSON RAMBLER-The best-known and most popular of all the climbing roses. A rapid grower, making sometimes 10 to 15 feet in a season; flowers are borne in clusters of 15 to 25 perfectly shaped blossoms of a rich glowing crimson; when in full bloom the vine appears to be a perfect mat of rich red flowers; perfectly hardy everywhere.

DR. W. VAN FLEET-No other climbing Rose has ever created such favorable comment as Dr. W. Van Fleet, for the flowers are so perfect in every way-form, color, delicate fragrance-and borne on such long, strong stems. The splendid, hearty growth, beautiful shiny bronze-green foliage, crimson thorns, and perfect hardiness, added to the exquisite blooms, make this the choicest Rose in this class. The color is a remarkable, delicate shade of flesh-pink on the outer surface, deepening to rosy-flesh in the center. Flowers full and double, delicately perfumed; buds pointed; stems 12 to 18 inehes long, fine for cutting.

DOROTHY PERKINS-This is one of the new Rambler types; has the same strong habit of growth as the Crimson; flowers are borne in large clusters of 25 to 30 and are a beautiful shell pink; individual flowers are larger than those of Crimson Rambler.

EXCELSA (Red Dorothy Perkins)-This is identical with Pink and White Dorothy Perkins in growth and blooming qualities. The color is a brilliant crimson, making it one of the most showy roses grown.

PAUL'S SCARLET CLIMBER-No other rose in any class can compare with it for brillianey of color, which is a vivid searlet. This color is maintained without burning or bleaching until the petals fall. It makes a brilliant display during long season. Blooms are of medium size, semi-double, very freely produced in clus. ters of three to six flowers each. Plants are literally covered with flowers from top to bottom. It is of strong climbing habit and perfectly hardy.

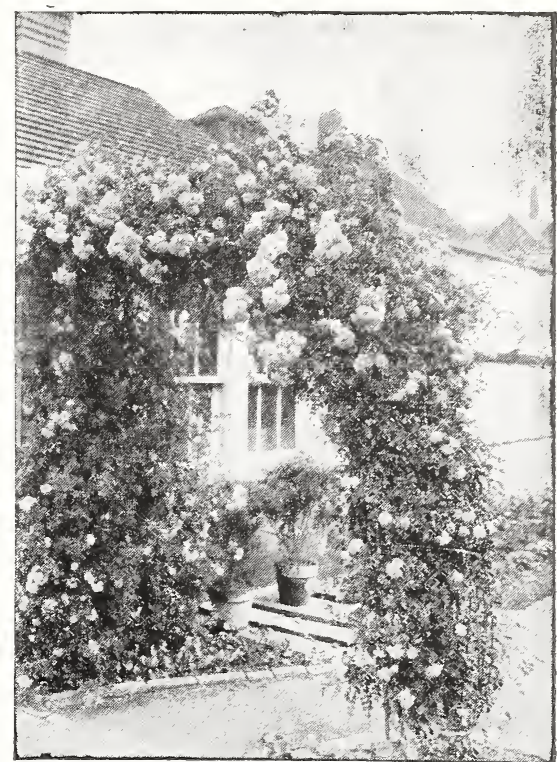

TAUSENDSCHON (Thousand Beauties) - A rapid growing, almost thornless climber showing the blood of the Rambler, Polyantha and Tea par. entage. Its innumerable flower clusters make a pretty show in June and July; at first, the soft pink of Clotilde Soupert, and later deep. ening to a bright red carmine rose.

WHITE DOROTHY PERKINS-A beautiful white flowered counterpart to the pink Dorothy Perkins; vines are a sheet of white during blooming season; are good white roses.

WHITE RAMBLER-Flowers are pure white, very double and remain on the vine a long time.

YELLOW RAMBLER-Same as the Pink, excepting flowers are a light yellow, changing to straw color; very fragrant.

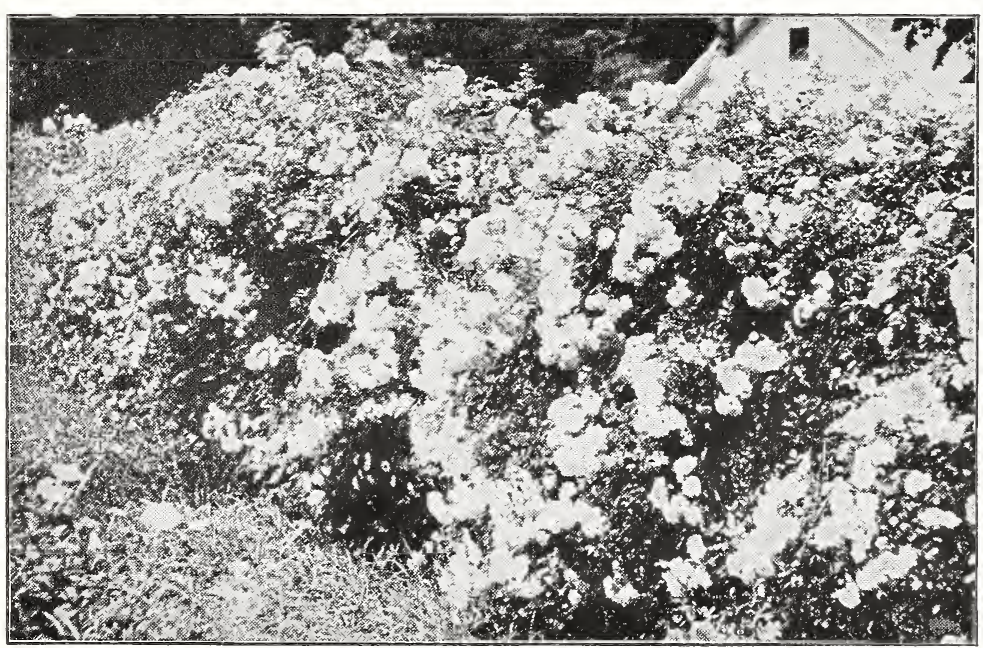

Hedge of Dorothy Perkins Roses

\section{Miscellaneous Hardy Roses}

MADAM PLANTIER-Flowers pure white of medium size; full, somewhat rosy in the bud form; produced in greatest abundance quite early in the season. The leaves are small; the bush hardy and spread. ing. Fine for masses, hedges, borders, cemeteries, ete.

PERSIAN YELLOW-Similar to above, but with flowers fuller and of better form. Bright yellow; the most double of this class. The earliest hardy yellow rose. 


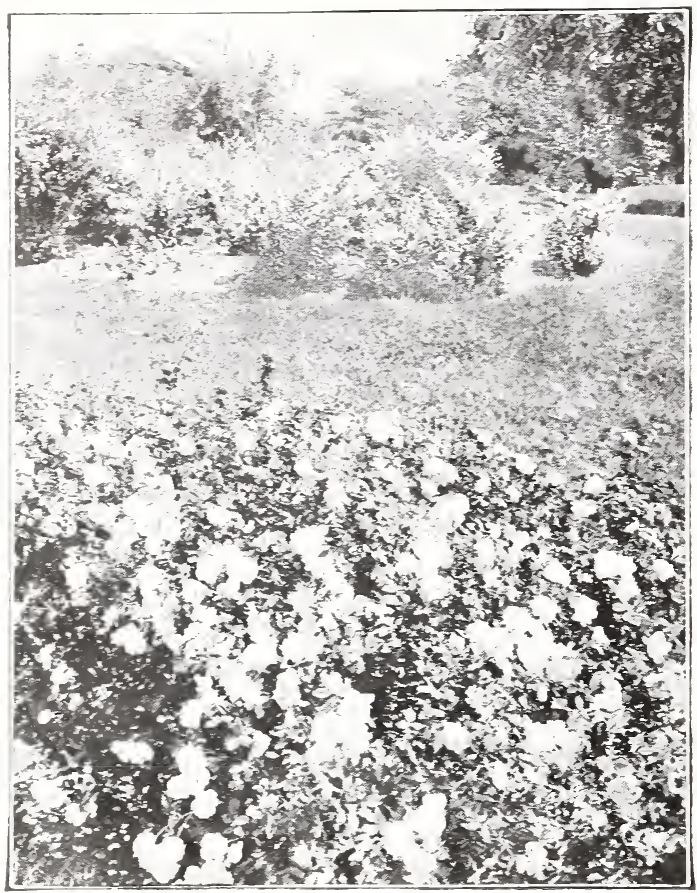

Madam Plantier (Description on page 31)

\section{Baby Rambler Roses}

BABY DOROTHY - In color and form resembles Doroths Perkins. When in full bloom, plant almost hidden by the flowers.

BABY RAMBLER-One of the best hardy bedding roses; flowers are borne in clusters of 20 or more to the cluster. Perfectly hards and is good for pot culture for winter blooming. Color a bright crimson-pink.

WHITE BABY RAMBLER. The same as Baby Rambler, with white flowers.

\section{Rugosa Roses}

The Rugosa Roses are especially suited for our northern climate, owning to their extreme hardiness and sturdy growth. The foliage of these Roses is most beautiful, being a shining, rich dark green and very wrinkled. The blossoms are usualle single, but rery large and showy, and followed in autumn with a profusion of beauti. ful orange-red or crimson fruits. The plants do well for seashore planting, mountains, or most anrwhere. Excellent for hedges or for planting among shrubbers or hards borders.

F. J. GROOTEXDORST-This hrorid is unlike ant other Rugosa in haring the beautr and freedom of bloom of the Babr Ramblers, but with the rugged foliage and hardiness of the Pugosa. It was originated by a Holland nurs. errman and introduced br F. J. Grootendorst, for whom it is named. In luxuriance of bloom, and in sturdiness, this rose has fairly leaped into the greatest popularitr. It is the grandest of the red flowered Babr Ramblers, and blooms continually all summer. Splendid for low hedges or edgings.

RUGOSA ALBA-Single pure white flowers, high. ls scented, followed br pretty berries.

RUGOSA RLBRA-Foliage shinr bright green, flowers deep rose, produced in fine, large clusters. Beautiful bright red berries in autumn; excellent for planting on the lawn with shrub. bers or in groups. or used for hedges.

\section{Moss Roses}

The great hardiness, together with the mossiness of the buds and stems of this group, make it a unique and beautiful group.

CRESTED MOSS-Pink, sweetly perfumed; beautifully crested buds.

PERPETLAL WHITE-Pure white, blooms in clusters, double, beautiful, rigorous.

SALET-Clear rose color, rerr double, of rigorous growth and abundant bloom. Perpetual.

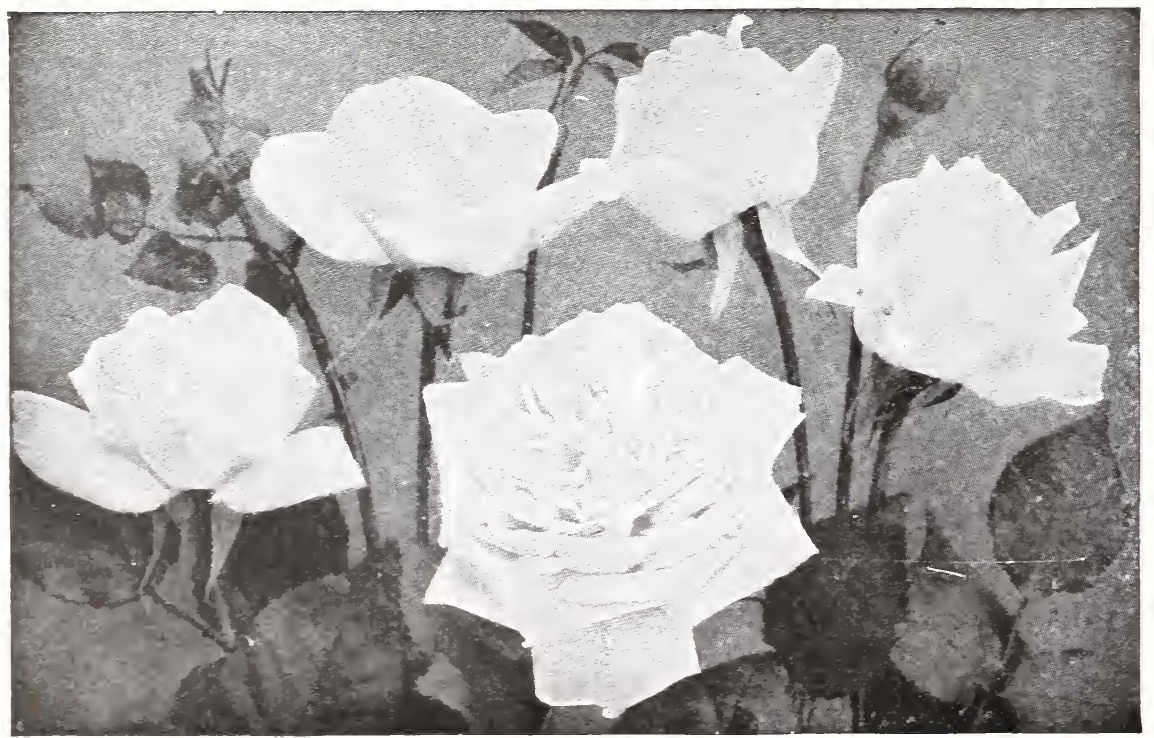

Irs. Aaron Ward Description on page 30) 


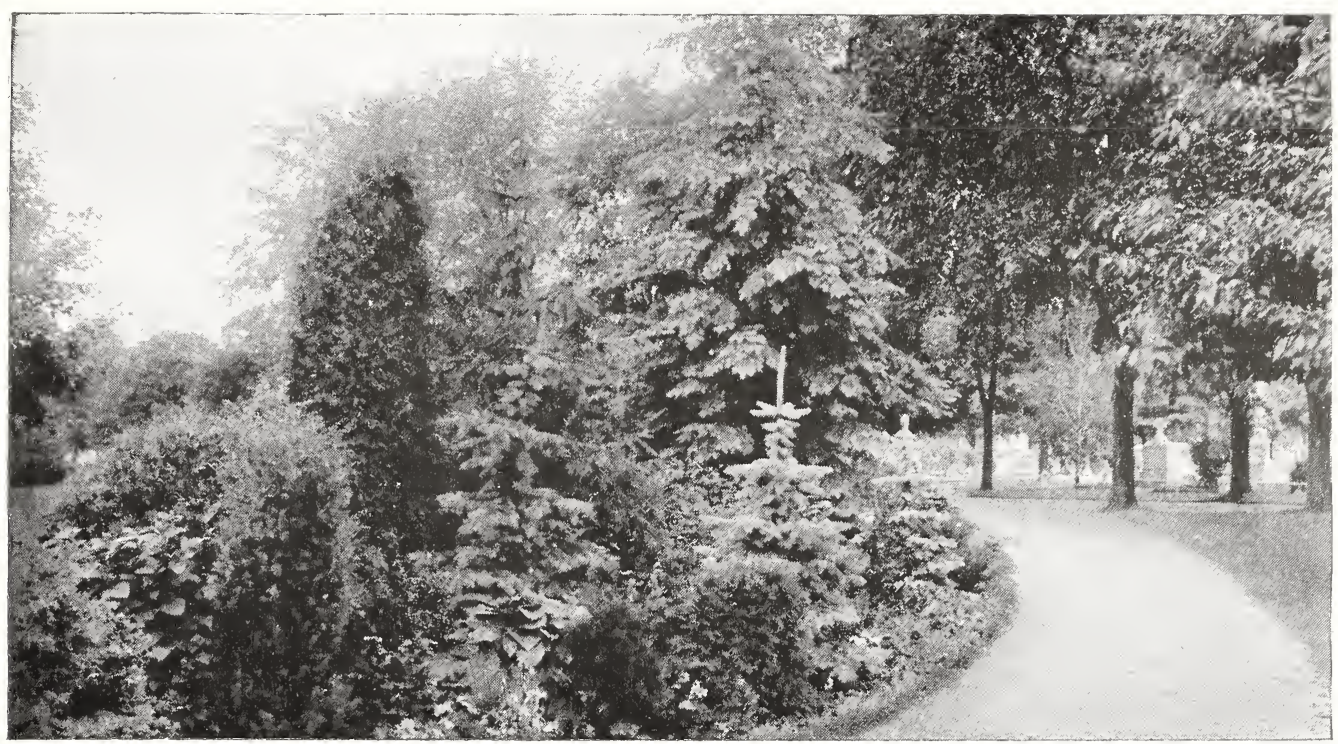

\section{Deciduous Trees}

$\mathbf{T}$

HERE is an untiring loveliness in trees as they continually change with the seasons. At the first breath of spring, the swelling buds open into dainty flowers, often inconspicuous, but none the less beautiful. Then follows the delicate tints of expanding leaves that deepen into the richness of mid-summer greens. The chill of autumn brings new beauty in the myriad of gorgeous hues that come almost overnight. Even in the bleak, cold days of winter there is beauty in bark and twig and form.

\section{ASH-Fraxinus}

AMERICAN WHITE ASH (F. Americana)-A well-known native tree; tall, very straight, with broad, round head and dense foliage.

BLACK LOCUST (R. Pseud-acacia) - A native tree of large size, rapid growth, and valuable for timber as well as ornamental; flowers are white or yellowish, very fragrant and appear in June.

BOX ELDER or ASH LEAVED MAPLE (A. Negundo)-Large spreading tree of rapid growth, 70 feet high; foliage smaller than in other maples; very frequently planted for wind-breaks. Very hardy.

\section{CATALPA}

CATALPA BUNGEI (Umbrella Catalpa)Grafted on stems six to eight feet high, it makes an umbrella-shaped top without pruning. Perfectly hardy and flourishes in almost all soils and climates. Leaves large, glossy, heart-shaped, deep green; lie like shingles on the roof; always make a symmetrical head. One of the most unique trees; a valuable acquisition, desirable for lawn, park and cemetery planting.

CATALPA SPECIOSA-A variety which is said to have originated in the West; it is very hardy and a rapid grower and is being extensively planted for commercial purposes; has broad, deep green leaves and beautiful large blossoms, making it a highly ornamental tree for lawn or street. Valuable for planting in groves for growing poles, posts and railroad ties.

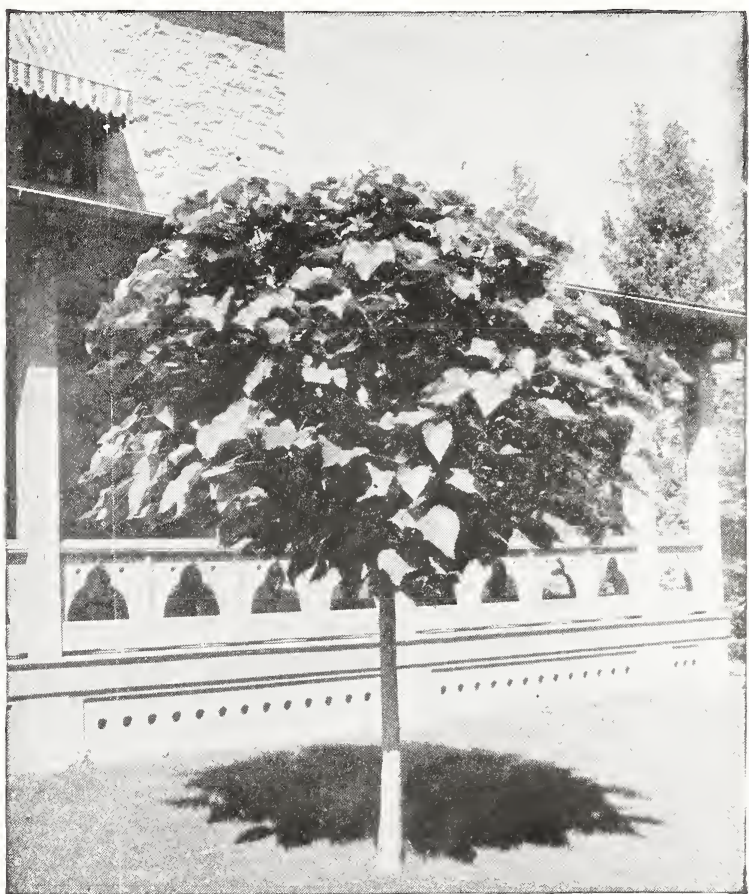

Catalpa Bungei 


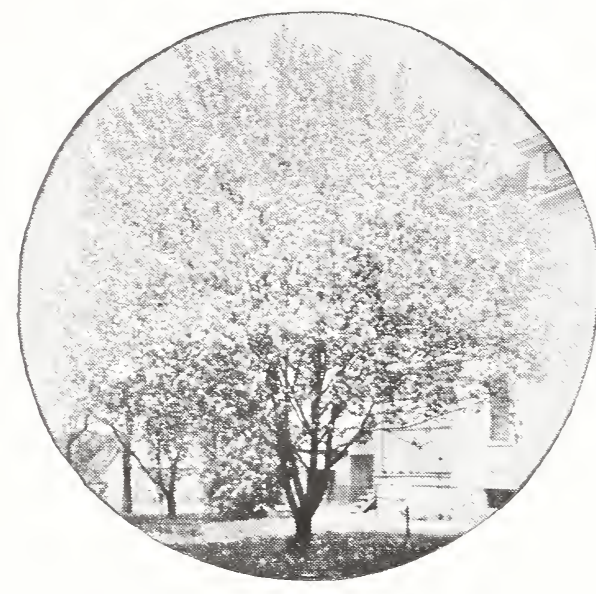

Bechtel's Double Flowering Crab

\section{CRAB-Pyrus}

BECHTEL'S DOUBLE FLOWERING CRAB (P. Angustifolia)-One of the most beautiful of the flowering crabs; tree of medium size, corered in early spring with large, beautiful fragrant flowers of a delicate pink color; rery popular for lawns, as it blooms quite young.

\section{ELM-Ulmus}

AMERICAN White ELM (U. Americana)-A magnificent tree growing 80 to 100 feet high with drooping spreading branches; one of the grandest of our natice trees; makes a beautiful lawn or street tree.

\section{HACKBERRY}

Resembles Elm somewhat, foliage more pointed and a bright glossy green, bark thick and rough; a symmetrical grower; good street tree, drouth resistant.

\section{HONEY LOCUST}

(C. Tricanthus) - A rapid-growing native tree with powerful spines and delicate foliage; the greenish flowers appearing in early summer are followed by flat pods 8 to 10 inches long; used extensirely for hedges.

\section{HORSE CHESTNUT-Aesculus}

COMMON or WHITE FLOWERING (A. Hippocastanum)A handsome tree of regular form with showy foliage and corered in the spring with panicles of white flowers marked with red.

\section{LINDEN-Tilia}

AMERICAN LINDEN or BASSWOOD (T. Americana)-Grows about six feet high, rapid growing, large size, forming a broad round top-head; leares broadly oral, dark green above, light green underneath; flowers are creamy-white and fragrant; a splendid street or lawn tree.

EUROPEAN LINDEN (P. European)-A rery fine pyramidal tree of large size with large leaves and fragrant flowers; the leares change in fall to beautiful tones of yellow and brown.

\section{MAPLE-Acer}

NORWAY MAPLE (A. Platanoides)-A large handsome tree, with broad, deep green foliage; has a rery compact growth; a raluable tree for parks, lawns or streets.

SCHWEDLER'S PURPLE MAPLE (A. Platanoides Schwedleri)-A beautiful variety with very large bronze-red

\section{POPLAR-Populus}

CAROLINA POPLAR (P. eugeni)-Very strong growing tree of broad, columnar shape. Does not produce the annoying "cotton" of the native cottonwoods.

OMBARDY POPLAR (P. nigra italica).-In shape this is the exclamation mark among trees. Its towering spire has an indiriduality all its own. For tall sereens and backgrounds, this tree is admirable.

ORWAY POPLAR (Sudden Sawlog)-Tree rery hardy; is being planted quite extensively in many sections. Similar to Carolina Poplar in growth and appearance, but claimed to be of more rapid growth and retains its size better as it mounts upward, thus producing more lumber. Taluable for street and park planting; also for screens and shelter belts.

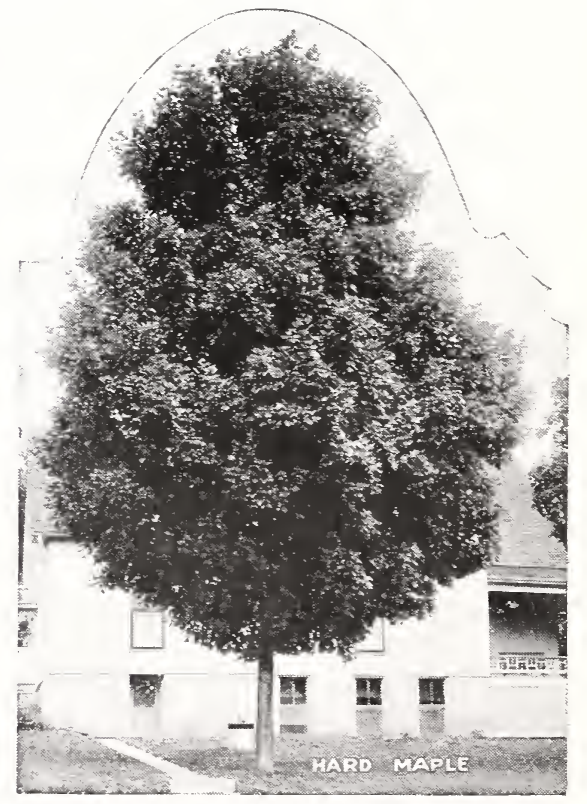

Sugar Maple 


\section{RED BUD-Cercis}

JUDAS TREE or RED BUD (C. Canadensis)-A medium size tree with large irregular head and perfect heartshaped leaves. The profusion of delicate reddish-pink blossoms with which it is covered in early spring before the foliage appears make it one of the finest ornamental trees.

\section{SYCAMORE-Platanus}

AMERICAN SYCAMORE or PLANE TREE (P. Occidentalis)-A well-known tree. Viery oommon throughout the United States; leaves heart-shaped at base, short lobes sharp pointed; branches are wide spreading.

ORIENTAL PLANE Or EUROPEAN SYCAMORE (P.Orientalis) - A rapid growing, erect tree with bright green foliage; much more esteemed than the American variety as a shade tree; very desirable for parks, street and lawn.

\section{TULIP TREE-Liriodendron}

TULIP TREE (L. Tulipfera)-A magnificent rapid growing tree of pyramidal form attaining a height of 150 feet, with light green, glossy fiddle-shaped leaves and greenish-yellow tulip-shaped flowers; also known as white wood.

\section{BLACK WALNUT_Juglans Nigra}

This species is a common and stately forest tree in the middle and Western states; grows from forty to sixty feet high; has an open, spreading head and is rapid in growth; produces large crops of nuts with rough hard shell containing rich, oily kernel of fine flavor.

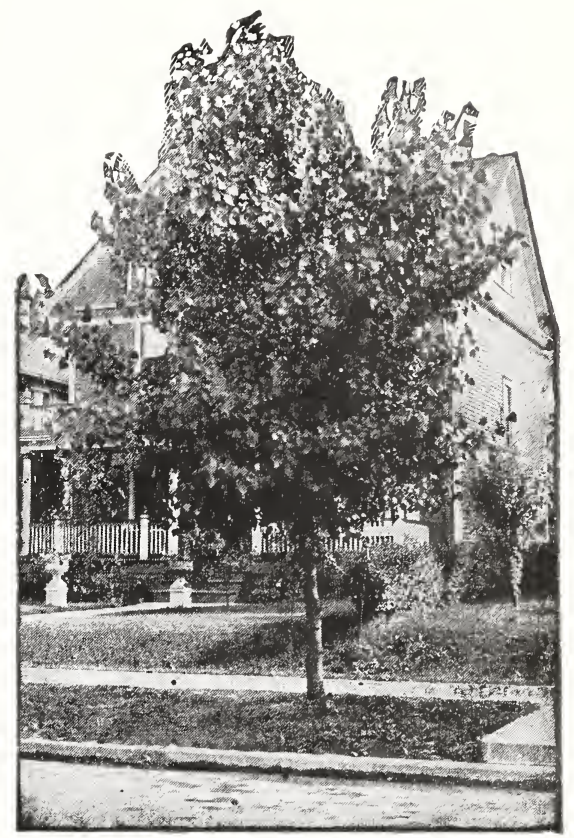

Carolina Poplar

\section{WEEPING TREES}

\section{BIRCH}

CUT LEAF WEEPING (Betula Pendula Laciniata). An elegant erect tree with slender drooping branches and fine cut leaves. White bark.

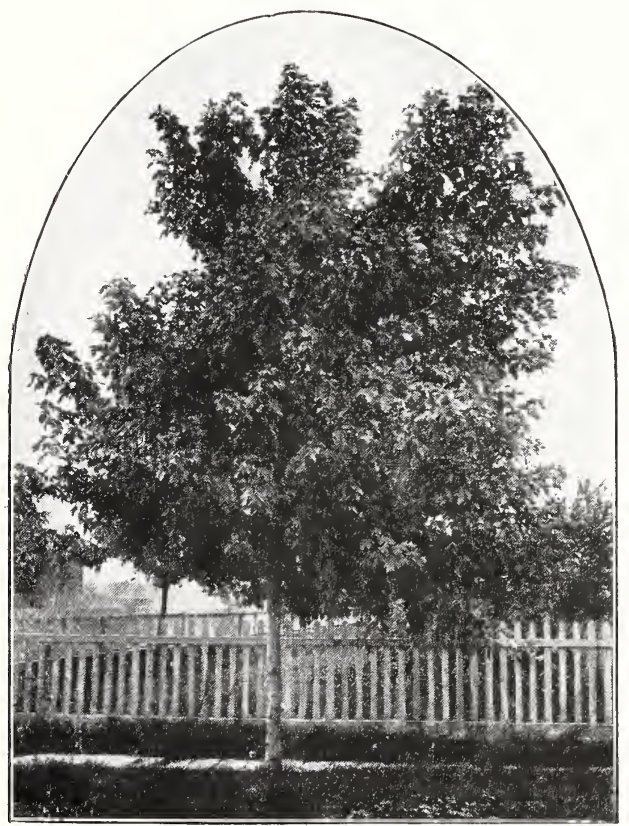

Silver Leaved or Soft Maple

\section{ELM}

CAMPERDOWN WEEPING (Ulmus Montana Camperdown Pendula).-Its vigorous irregular branches, which have a uniform weeping habit, overlap so regularly that a compact roof-like head is formed.

\section{MULBERRY}

TEA'S WEEPING (Morus Tartarica Pendula).-A graceful and beautiful hardy tree, forming a perfect umbrella-shaped head, with long, slender, willowy branches, drooping to the ground and gracefully swaying in the wind; foliage small, lobed and of $a$ delightful, fresh, glossy green. The tree is exceedingly hardy, of rapid growth and abundant foliage, and can be trained into almost any shape.

\section{MOUNTAIN ASH}

WEEPING (Sorbus Aucuparia Pendula).-A beautiful tree; straggling, weeping branches; makes a fine tree for the lawn; suitable for covering arbors; hardy.

\section{WILLOW-Salix}

BABYLONIAN WEEPING WILLOW (S. Babylonica)The well-known, common weeping willow; makes a large tree covered with drooping branches.

WISCONSIN WEEPING WILLOW (S. Babylonica, var dolorosa)-Of drooping habits and considered the hardiest; valuable on account of its ability to resist severe cold. 


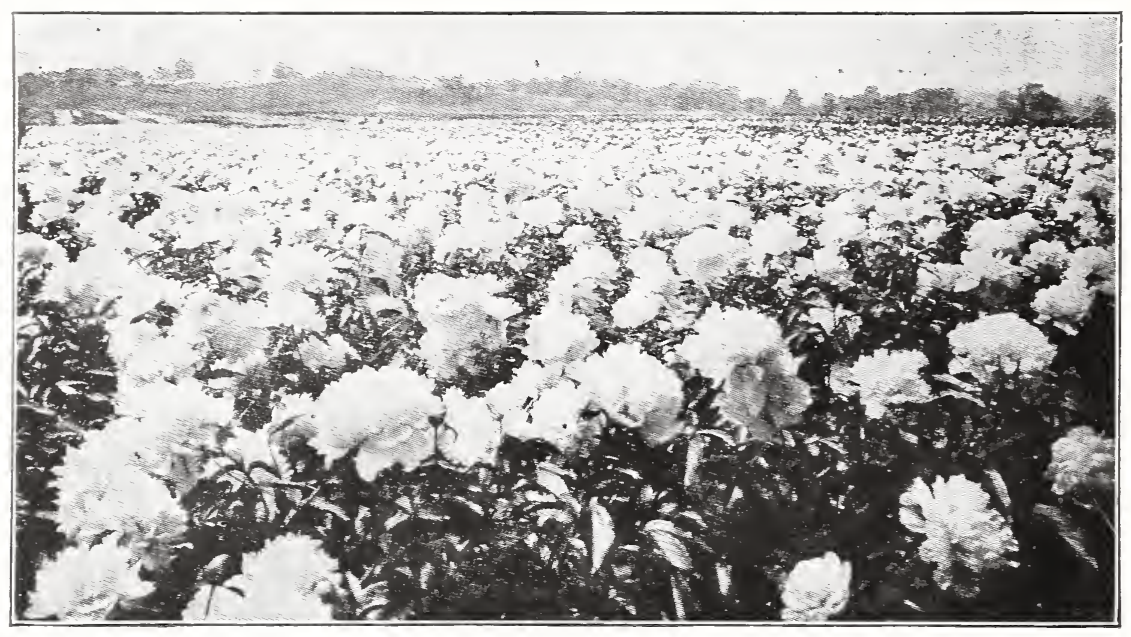

A Wealth of Peonies in Bloom

\section{Peonies}

\section{The Queen of the Garden}

$\mathbf{N}$

O FLOWERS exceed the Peonies in popularity, and none are more easily grown. They are seldom attacked by insects or disease, and are perfectly hardy, requiring no covering in the severest weather. They thrive in all kinds of soil and flourish in a rich deep loam.

No hardy perennial is of more permanent value than the Peony. The first cost is the only cost, and they continue to increase in size and value for many years. The foliage is rich and of beautiful deep green color, which renders the plant very ornamental even when out of flower, and no other flowers are so well adapted for interior decoration and none make more massive color effect when planted in a border or in a bed on the lawn. Their popularity has increased during the past few years since the new improved varieties have been disseminated. Peonies range in color from cream and pure white through the various shades of pink and red to the deepest purple and maroon, in all possible combinations of tint and form.

Distance to plant, 2 to $2 \frac{1}{2}$ feet apart. For field culture rows should be $31 / 2$ to 4 feet apart.

Plant Peonies so that the tops of the crowns or eyes are three inches under the surface of the ground. A covering of leaves, straw or manure late in the fall will protect them during the winter. This should be removed early in the spring.

\section{WHITE VARIETIES}

FESTIVA MAXIMA-Large, full double bloom, color pure white with an occasional carmine spot; strong grower; one of the best of the white varieties. Early.

QUEEN VICTORIA-Medium size, loose globular flower with fine broad guard petals. Opens flesh white, fading to milk white. Center petals tipped with coral blotches. Fragrant. Free bloomer. Extra good in bud. The very best commercial white. Mid-season.

MARIE LEMOINE. Enormons, solid irory-white.
Deepening to chamois in center. Tery fragrant. This exquisite flower stands absolutely at the head of late white peonies.

MME. DE VERNEVILLE-Tery large, finely formed, anemone shaped flower. Guard petals sulphur white. Center petals rose-white with carmine touches. Flower of good substance. Stems long and strong. An ideal cut flower. Later than Festiva Maxima and equal if not superior in beautr. Pleasing fragrance. We con. sider this one of the best whites if not the best. 


\section{PINK VARIETIES}

EDULIS SUPERBA-Pink. Large, loose crown type. Bright pink with slight violet shadings at base of petals. Fragrant. Early, strong and upright in habit, very free bloomer. Best early commercial pink.

FLORAL TREASURE-Pink. Large, compact bloomer of a delicate all one color pink, borne in great profusion on erect, medium length stems. One of the best allaround peonies. Extra fine as a commercial sort. Fine to plant for low hedge where one color is desired. Midseason. Extra.

GRANDIFLORA-Pink. Very large, flat rose type. Very fragrant. Tall, erect, strong grower. Very late. Many consider this the best late variety of its color.

MME. GEISSLER-Pink. Rose type, compact, imbricated, well formed bloom on strong, erect stems. Color glossy pink, shading to bright bengal rose on base of petals; fine, large, very double, globular, imbricated, massive and imposing. Mid-season.

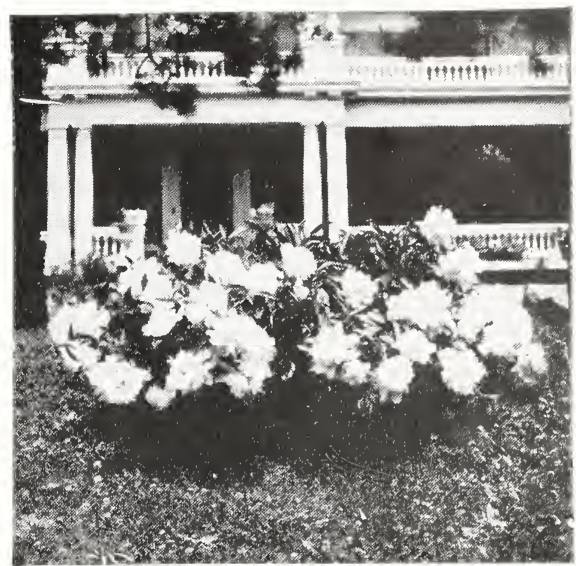

Festiva Maxima (See page 36 )

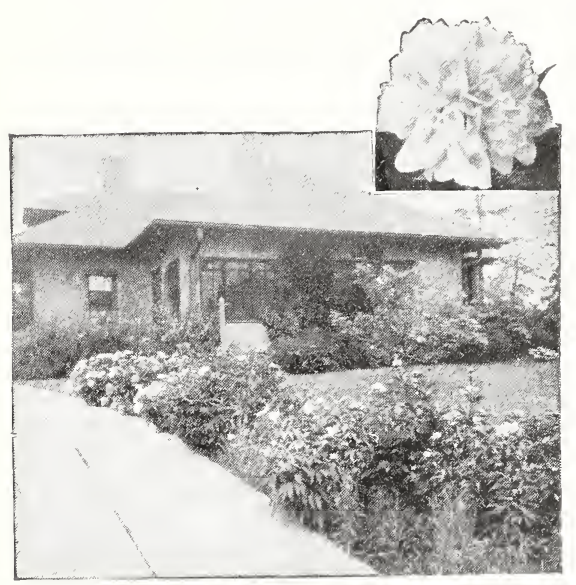

Border of Peonies

MONSIEUR JULES ELIE-Pink. Very large, compact bomb type. Large guard petals surrounding a great dome of incurved petals. Glossy flesh pink shading to a deeper rose at the base, the entire bloom covered with a silvery sheen. Strong stems of medium height. Very fragrant. This, in our opinion, is the most beautiful of the bomb-shaped peonies. A long keeper. Early.

PERFECTION-Pink. Rose type, very late. Very large double flowers of perfect shape. Delicate shell-pink or lilac-white, base of petals shaded deeper. Fragrant, vigorous, upright grower. Very good.

\section{RED VARIETIES}

DELACHEI-Red. Late midseason, compact, rose type, Deep purple, crimson reflex, a very sure and free bloomer. One of the best of the dark reds.

FELIX CROUSSE-Red. Large, compact. Deep rose red. Fragrant. Strong robust grower. Free bloomer. Called by many growers the best one-color red in cultivation. Medium season.

FRANCOIS ORTEGAT-Red. Large flower of semi-rose type. Dark amaranth red showing stamens. Plant of medium height. Mid-season.

KARL ROSENFIELD-Very large, globular, compact, semi-rose type. Dark crimson. Very strong, tall, compact grower and free bloomer. Mid-season. A very brilliant and striking variety. Slightly fragrant, agreeable. Splendid keeper as cut flower.

OFFICINALIS RUBRA-Red. A large, round bloom of vivid crimson. This is the old deep bright red peony of the old-time garden. Earliest of all good peonies. Very desirable in this latitude, as it is generally in

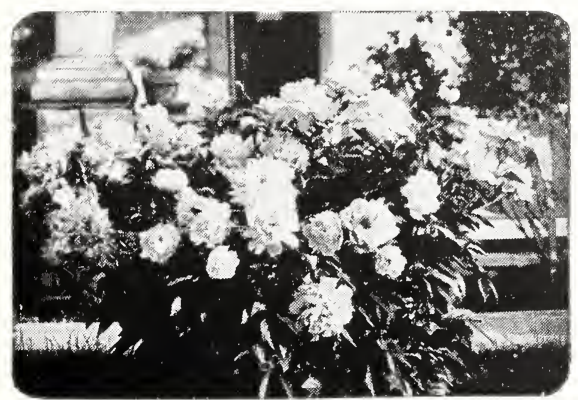

Edulis Superba bloom on Dee. oration Day. The red "piney" of our grandmothers g a $\mathrm{rd}$ e $\mathrm{n}$. As good as the new varieties and earlier. $\mathrm{Noth}$ i n g to take its place.

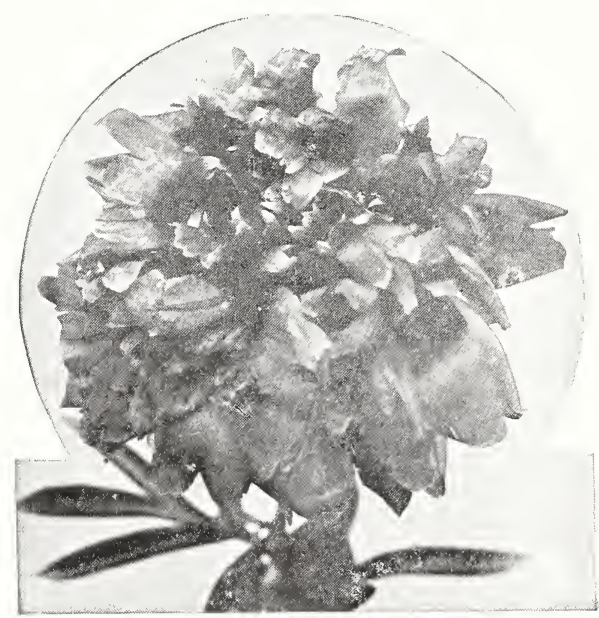

Rubra Superba

RUBRA SUPERBA-Large, compact, informal rose type; deep rose-carmine or crimson, fragrant; medium grower and bloomer; very late; considered the best of very late. varicties. 


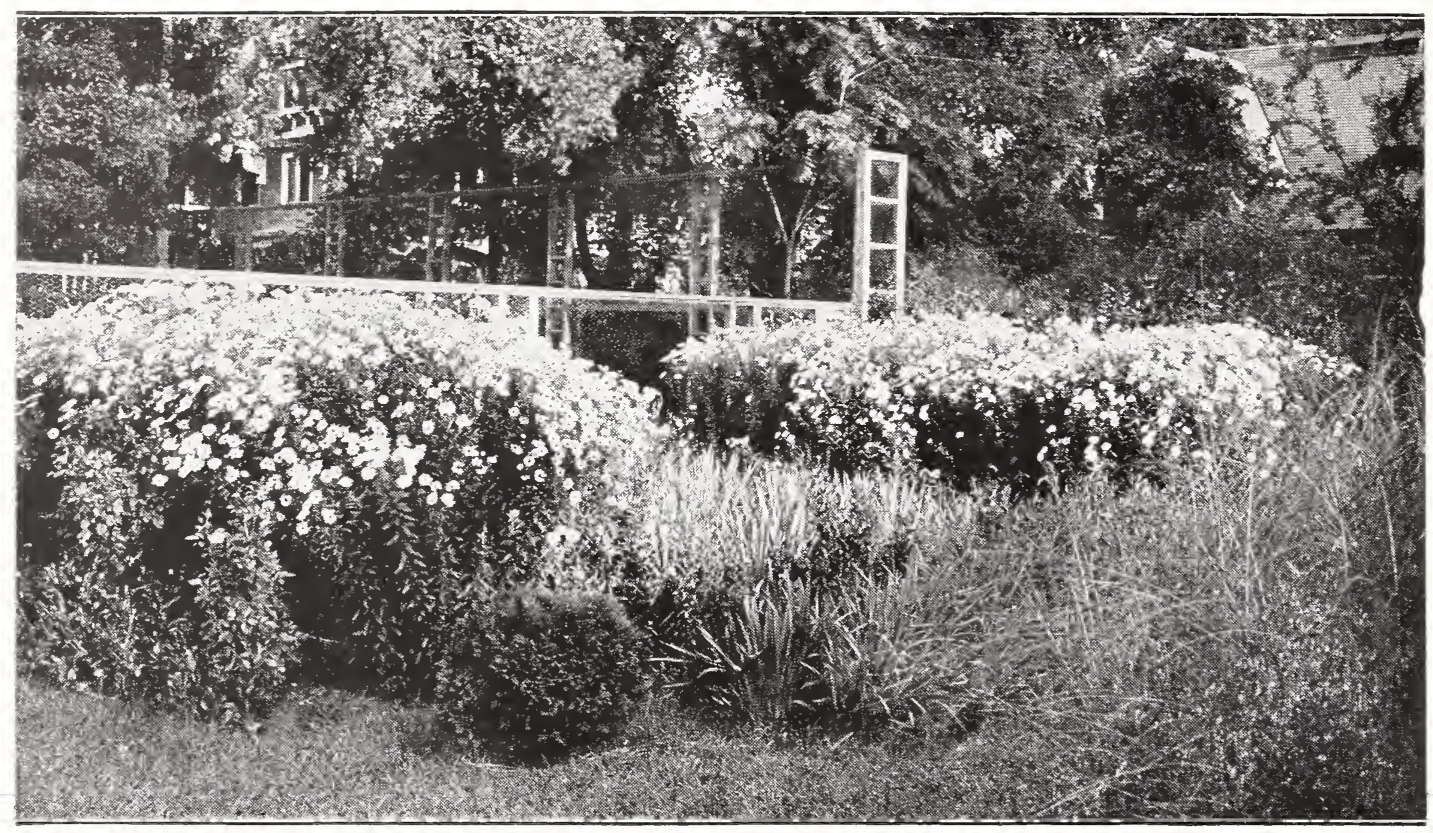

Shasta Daisies

\section{Hardy Perennial Plants}

7 HESE can be used to best advantage in groups and beds on the lawn, as borders for drives, 1 walks, or in front of shrubbery and in the garden. Some of the tall-growing sorts may be planted in among the shrubbery with good effect. Soil should be kept well fertilized. A light covering of coarse, strawy manure or something that will not pack is beneficial in winter.

\section{ACHILLEA PTARMICA}

"The Pearl," Milfoil-Bears great masses of small pure white flowers on long stems, all summer. Fine for cutting. Height 12 to 18 inches.

\section{ANCHUSA ITALICA}

Bearing panicles of clear sky-blue flowers; a very useful perennial growing three feet high and blooms freely from June until September if not allowed to seed.

\section{ASTER TATARICUS}

TATARIAN ASTER-Very tall growing; excellent for the hardy border because of its late flowering. Blossoms purplish.

\section{BOLTONIA-(var. Latisquama)}

Aster-like flowers in a broad head; rosy purple; free blooming, showy and fine; 5 feet; July to October.

\section{BUTTERFLY BUSH-Buddleia}

So named because blooms attract large numbers of butterflies. This fact makes the plant very interesting, especially to children. Matures first year and lies down like a peony. Blooms profusely, lilac colored tapering panicles, 6 to 10 inches long. Height 3 to 4 feet.

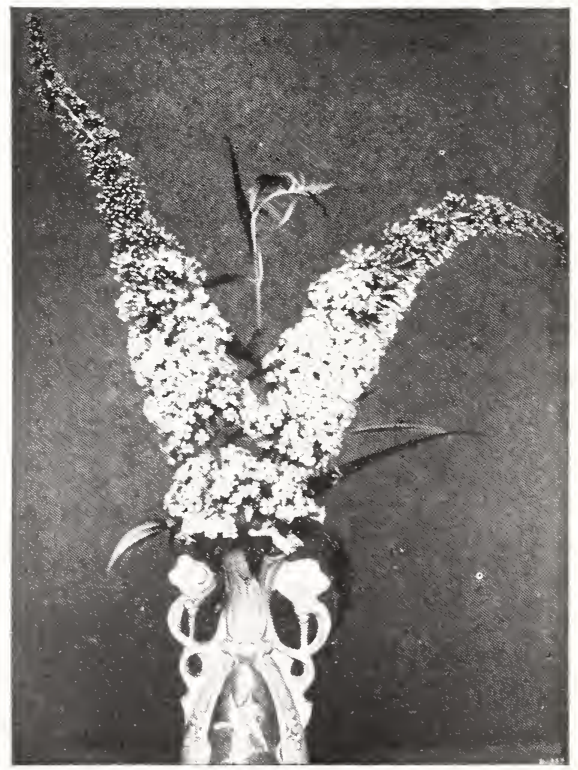

Butterfly Bush 


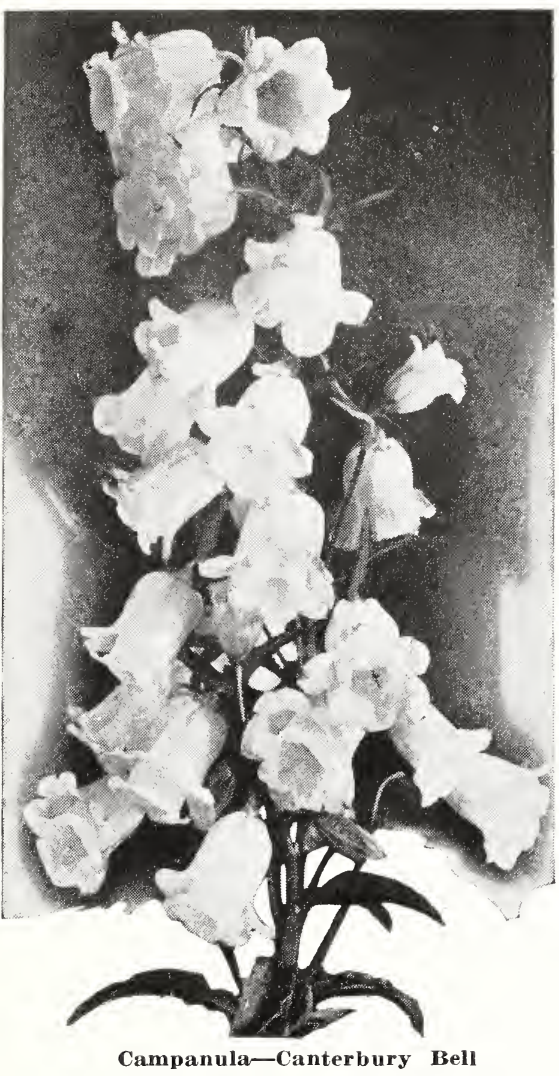

SHASTA DAISY

Large, snowy-white flowers four inches across; in bloom all summer; a good cut-flower variety.

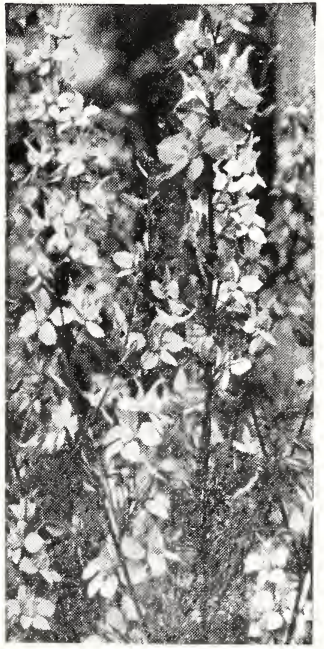

Delphinium

\section{DELPHINIUM} (Perennial Larkspur)

Indispensable to the herbaceous garden. Their long, showy spikes of flowers persist from June until frost and furnish the most satisfactory blues to any color scheme.

\section{DIGITALIS-Foxglove}

The spire-like flowering shoots of this lovely plant possess a dignity and elegance unequalled by any other garden flower. The stems range from 3 to 5 feet tall, bearing spirelike racemes of drooping, thimble-like flowers of great beauty. Various shades from white to purple.

\section{GAILLARDIA-Blanket Flower}

Among the showiest and most profuse bloomers. The plants are compact, growing from 12 to 18 inches tall; begin blooming in June and continue until frost. Flowers in rich shades of dark red and yellow.

\section{CHRYSANTHEMUM}

vender, mahogany, pink, red, white and yellow. This class of beautiful plants is now so universally popuar for outdoor bedding, and justly so. They prouce a lavish profusion of blooms, giving color, life beauty to the garden at a time when other plants been nipped by frost. They are quite hardy, is well to give them a slight covering of leaves eet high.

\section{CAMPANULA-Canterbury Bell}

good garden flower producing a great profusion of gaily colored blooms. Assorted colors.

\section{COREOPSIS GRANDIFLORA}

Tickseed. Flowers rich golden yellow. Blooms coninuously. Good for cutting. Height 2 to 3 feet.

\section{DESMODIUM-Penduliflorum}

beautiful Japanese perennial, with clover-like folige and long, pendulous racemes of rosy-purple flowers. The stems are four feet long, and in early autumn are literally loaded with the flowers. Very hardy and showy, and a fine plant for growing in ront of shrubbery.

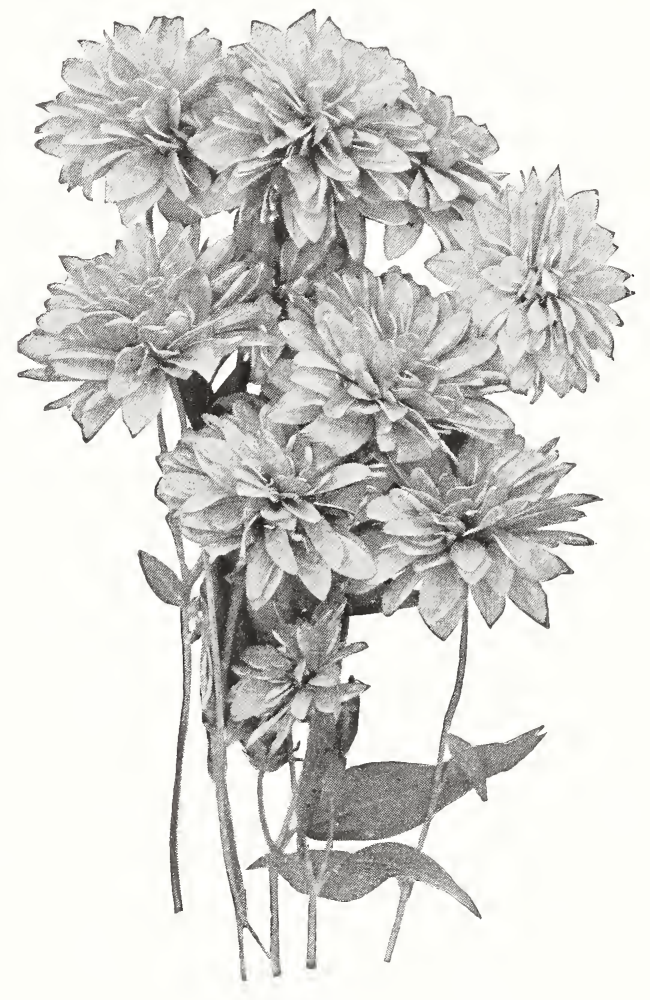

Golden Glow

\section{GOLDEN GLOW}

We call attention to this notable novelty and offer it as the finest herbaceous border plant introduced for many years. It is of easy growth and is giving complete satisfaction. But few plants can vie with it in attractiveness. There is no floral novelty before the public to be compared to it for effectiveness and worth. 


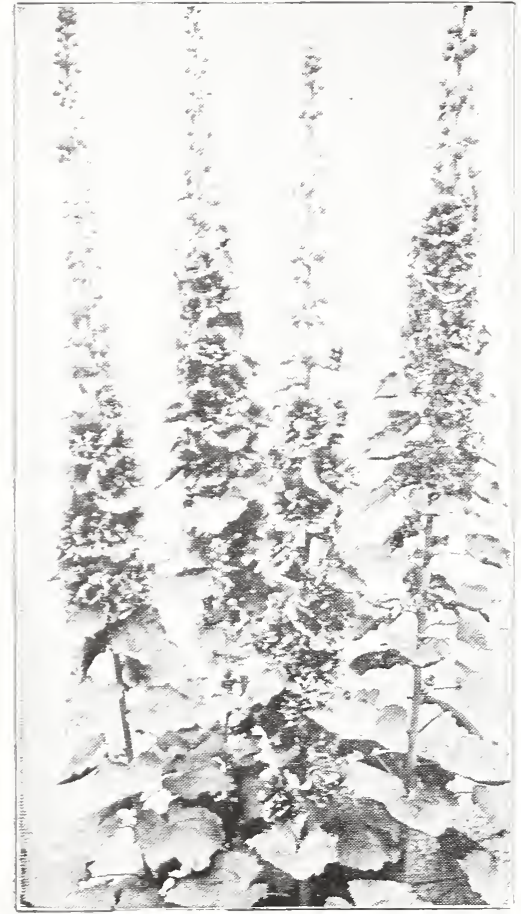

Hollyhocks

\section{GYPSOPHILA PANICULATA (Baby's Breath)}

Two or three feet in height and most graceful in effect, with list-like white flowers that are popular for cutting, as ther give an air for grace and harmony to ans arrangement. Blooms July to September.

\section{HIBISCUS-Mallow Marvel}

Without exception the finest production in the Hardy Plant line in rears. They make a bush-like growth from 5 to 6 feet high and 3 to $t$ feet across. The flowers are of enormous size, frequently $S$ to 10 inches in diameter, ranging in color from fier crimson through rarious shales of red, pink and white. It should be in every garden, as it is perfectly hardy, will thrive in ant locality or kind of soil, and blooms continuousl from July until late fall. Can furnish in separate colors red, pink or white.

\section{HOLLYHOCKS}

Thes e beautiful, mueh appreciated flowers make excellent screens and their tall flowering spikes and gay colors make them very decorative. We hare them in d o. u ble, and single flowers in assorted colors pink. white, red and rellow.

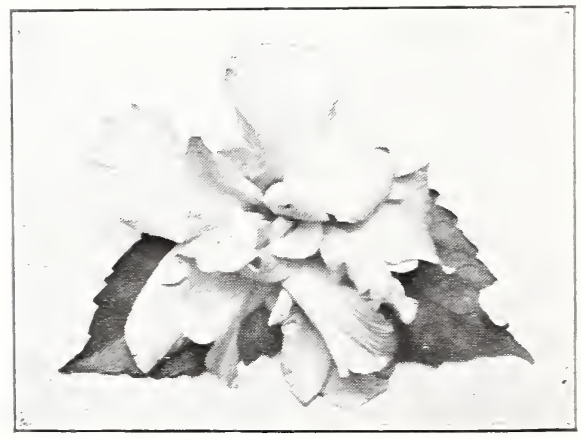

Hibiscus

\section{LILY-OF-THE-VALLEY (Convallaria)}

This is often starred and neglected and relegated to some poor corner, but this popular and fragrant subject, like most other plants, repays for being well treated, and if the bed is given a liberal top-dressing of well decayed manure in fall or early spring it will show the effect by increased size, number and vigor of the flowers. The stock we offer is strong clumps, especially suited for outdoor planting, which should be done before the end of April.

\section{IRIS GERMANICA German Iris}

The tall, sword-like leaves are interesting in themselres until the gorgeous flowers, with their unusual form, their beautiful variegation, and numerous shades of color, make their appearance in Mar. We hare a great number of different rarieties, in all colors.

\section{IRIS KAEMPFERI Japanese Iris}

In June and July, the 2-to-3-foot flower-stems are topped with flat, expanded. lightly poised, blossoms 6 to 9 inches across, in rich color combinations of white, blue, purple, larenderpink. lilac, rellow, and maroon. And the plants are hardy, requiring no protection in the coldest winters. Spreads rapidly.

\section{YUCCA FILAMENTOSA}

\section{Common Yucca}

The broad, strord-like, erergreen leares of this plant make it effective in low groups, or for edging. Flowering spikes often 8 feet tall, bearing hundreds of creamy white flowers. 


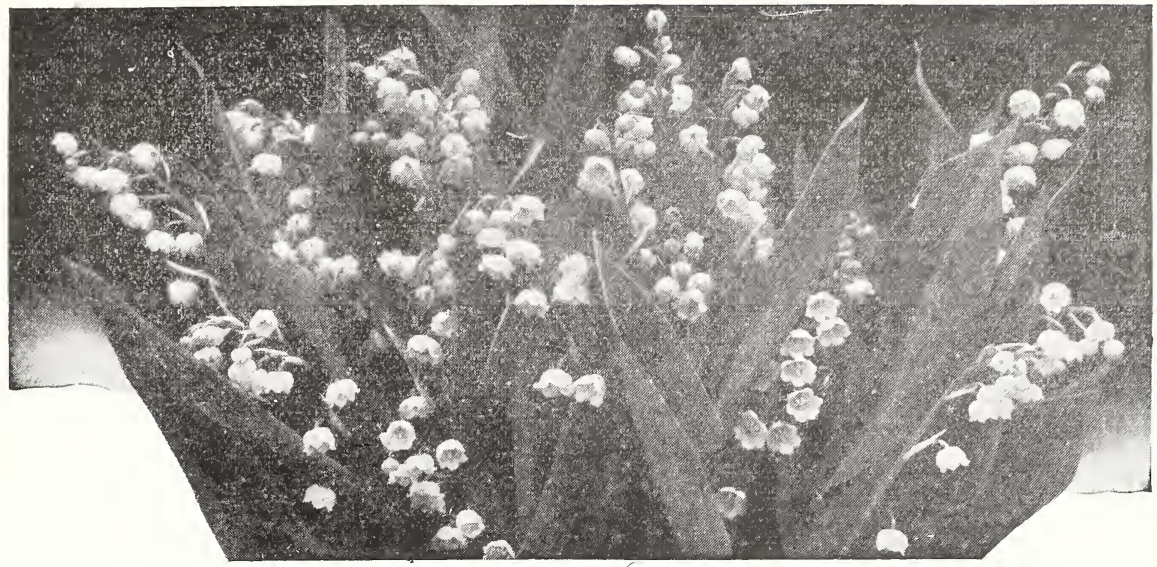

Lilies-of-the-Valley

\section{HARDY PERENNIAL PHLOX}

Phlox is one of the most easily grown hardy perennials, and the large number of beautiful varieties now offered makes it especially desirable. These noble flowers are not only beautiful as individuals, but the cheerful appearance of our gardens during the summer and autumn months is much indebted to them. They succeed in any position or soil, and can be used to advantage either as single specimens in the mixed border or as large clumps or beds on the lawn. The ease with which they are cultivated, their entire hardiness and the extended time of blooming, combined with the varied and beautiful coloring, make them especially valuable for garden planting. The perennial Phlox usually commence to bloom in early summer, and are brilliant with color until after several frosts have come.

Bridesmaid-White with crimson eye.

Champs Elysee-Rich purplish crimson.
Eclaireur-Tall, brilliant rosy magenta, large lighter halo.

F. G. von Lassburg - Purest waxy white, large trusses.

Isabey-Salmon pink.

Lothair-Bright erimson.

Miss Lingard-the finest white. Very early.

Rheinlander-Salmon pink, claret eye.

Richard Wallace-Pure white, with maroon eye. Rijnstroom-Beautiful clear pink. Very fine.

Rosenberg-Carmine-violet with red eye.

R. P. Struthers-Showy rosy carmine with elaret eye.

Sunset-Dark rosy red.

Thor-Largest salmon pink, with scarlet glow. Widar-Large reddish violet, white eye.

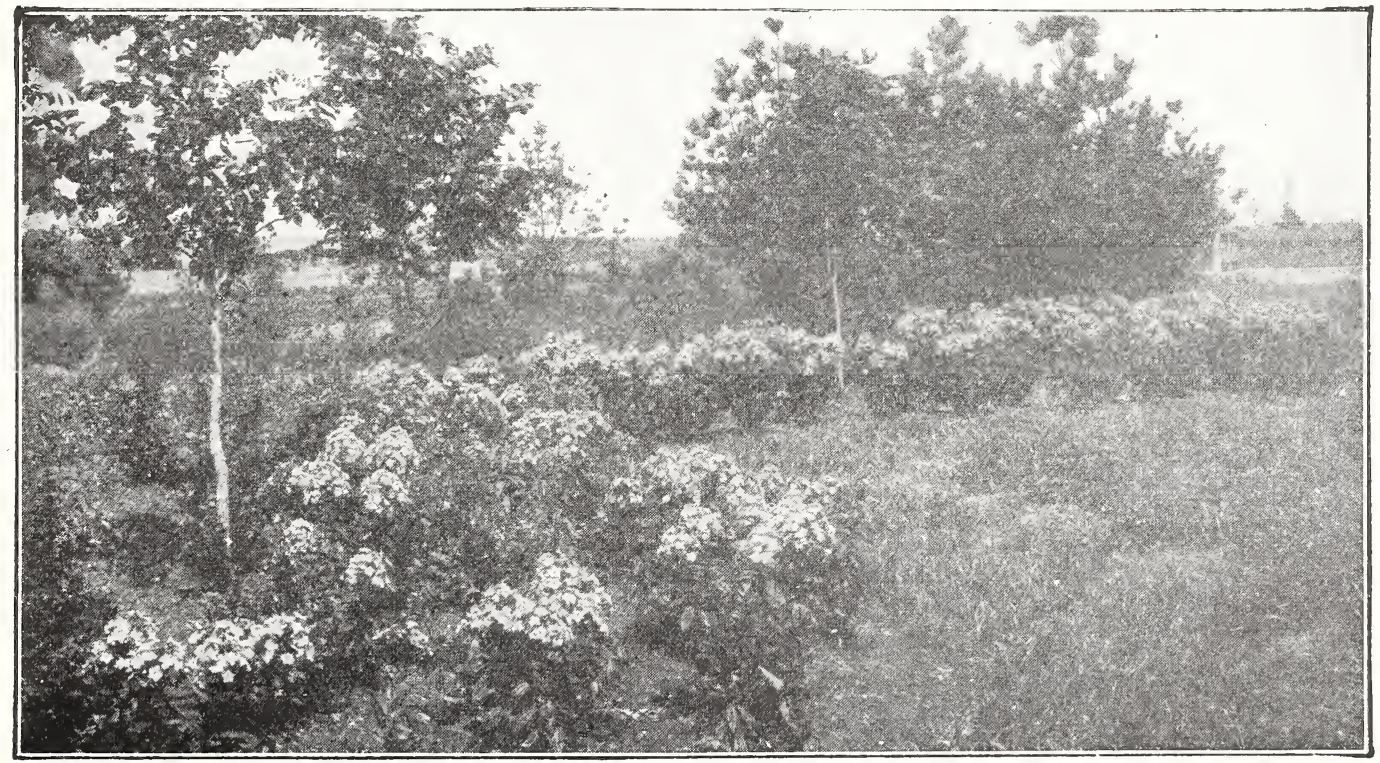




\section{Hardy Evergreens}

$I^{N}$

HANDLING and planting evergreens never allow the roots to become dry for an instant. Their juices are resinous, and when once dry, water has no power to restore them; dip the roots in "grout" or very thin mud, and plant quickly; cover the roots with fresh soil and with a heavy piece of wood beat the earth solid over them. Fill up and pound again, and finish by bringing fresh loose earth about the tree with a hoe. No wind can now bend the tree about so as to break the tender rootlets as fast as formed.

Use Scotch Pine, White Spruce, Norway Spruce, and White Pine for high screens, and Arbor Vitae or Red Cedar for low ones.

ARBOR VITAE (American)-This plant is, all things considered, the finest erergreen for hedges. It is rery hardy and easily transplanted, few plants failing if properly handled. It grows rapidly and with little care, or rather by easy management, it soon forms a most beautiful hedge. rerr dense and perfectly imperrious to the sight. It is nerer planted to turn stock, but it forms a most desirable and ornamental screen to diride the lawn from other grounds.

ARBOR VITAE (Pyramidalis)-A superb, new and hardy sort, of rery compact habit; much better than the Irish Juniper, and grown in a perfect column. Largely planted in cemeteries, owing to the small amount of space it occupies. This is perhaps the most valuable Arbor Vitae in cultiration.

BALSAM FIR-A handsome, compact, erect, pointed tree, with short, soft leares, which are dark green abore, silrery beneath, a good grower.

HEMLOCK-An elegant, pyramidal tree, with drooping branches and delicate dark foliage, like that of the Yew; distinct from all other trees. It is a beautiful lawn tree and makes a highly ornamental hedge.

IRISH JUNIPER-Very erect and tapering in its growth, forming a column of deep green foliage; a pretty little tree or shrub, and a general favorite for its beauty and hardihood.

NORWAY SPRUCE-A lofty, elegant tree of perfect pyramidal habit, exceedingly picturesque and beautiful. One of the best erergreens for windbreaks.

PINE AUSTRIAN or BLACK-A remarkably robust, hardy, spreading tree; leares long, stiff, dark green; growth rapid; raluable for this country.

PINE, SCOTCH-Is one of the most rapid growers while joung, one of the best for shelter planting in the West. It will make the best windbreak in the least time of any; it is a very valuable species.

PINE, WHITE-One of the best erergreens. The foliage is a warm, light green, often with a blush tinge. The leares, in fires, are three or four inches long, soft and delicately fragrant. It does not grow as rapidly the first few years

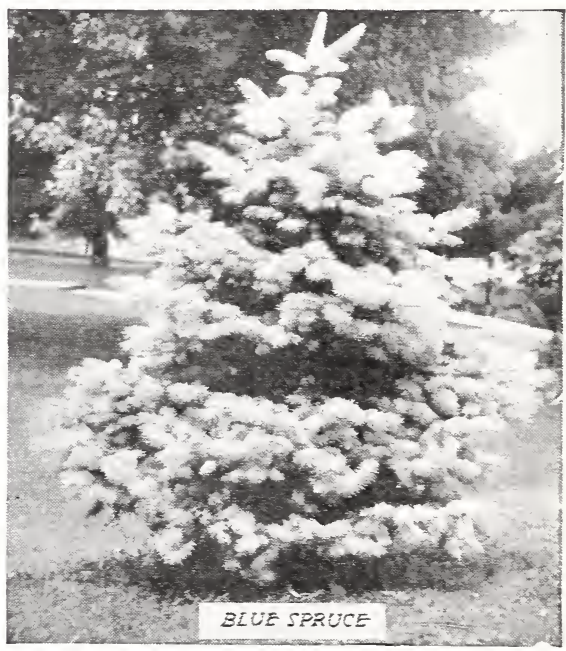

as some, but after being planted eight or ten sears it is the most rapid grower of all our erergreens.

RED CEDAR (J. Virginiana) - Well-known natire tree; raries much in habit and color of foliage; rery attractire in winter when the golden bronze of the foung growth contrasts with the dark green of the older.

SPRUCE, COLORADO BLUE-This species has been tested at rarious points on the prairies of the West and Northwest with perfect success, and during a temperature of 30 degrees below zero, in exposed situations, entirel uninjured. One of the hardiest erergreens and the most beautiful in color and outline. "This is the king of spruces, clothed in royal robes of silver and sapphire, a rery Kohinoor among the gems of the Rockies."

DOUGLAS SPRUCE (A. Douglasi-A natire of Colorado; large, conical form; branches spreading. horizontal; leares light green abore, silvery white below.

Our evergreens are given special care, handled carefully and transplanted frequently, so there is no danger in moving them from our nurseries. Each tree is planted so that it grows symmetrically and develops into a shapely specimen. 


\section{Successful Planting, Pruning and Care}

\section{CARE OF STOCK}

The bundles should be opened immediately, the roots dipped in water, then heeled in moist ground so that the mellow earth will come in contact with the roots and thoroughly protect them from the air, having the earth tramped solid about them.

When ready to plant, take up only a few at a time, puddle the roots and do not allow them to lie exposed to the sun or air.

The ground should be carefully prepared by deep plowing and firming down with a dise and harrow.

\section{PLANTING}

The holes for planting must be large enough to receive the roots freely, without cramping or bending them from their natural position. All broken or mutilated portions of the roots must be cut off so as to leave the ends smooth and sound. All trees should be planted two or three inches deeper than they stood in the nursery row; pack the soil very firmly about the roots by tamping with the feet or post tamper, being careful not to bark or break the roots. Leave three inches of the surface soil loose to serve as a mulch. If the ground is very dry apply one to two pails of water before this soil mulch is in place, and after the water has soaked away it can then be placed over the moist soil.

\section{SUitable distance FOR PLANTiNg}

Apples-30 to 40 feet apart each way.

Standard Pears and Cherries-20 feet apart each way.

Plums, Peaches and Apricots-16 to 18 feet apart each way.

Dwarf Pears and Quinces-10 to 12 feet apart each way.

Grapes-rows of 10 to 16 feet apart; 7 to 10 feet in rows.

Currants and Gooseberries-4 feet apart.

Raspberries and Blackberries-3 to 4 by 5 to 7 feet.

Strawberries, for field culture-1 by 3 to $3 \frac{1}{2} \mathrm{ft}$.

Strawberries, for garden culture-1 to 2 feet apart.

\section{NUMBER OF TREES OR PLANTS TO THE ACRE}

40 feet apart each way

30 feet apart each way

20 feet apart each way

18 feet apart each way

15 feet apart each way

12 feet apart each way

10 feet apart each way

8 feet apart each way

6 feet apart each way

5 feet apart each way

4 feet apart each way

3 feet apart each way

RULE-Multiply the distance in feet between the rows by the distance the plants are apart in the rows, and the product will be the number of square feet for each plant, which, divided into the number of square feet in an acre $(43,560)$, will give the number of plants or trees to the acre.

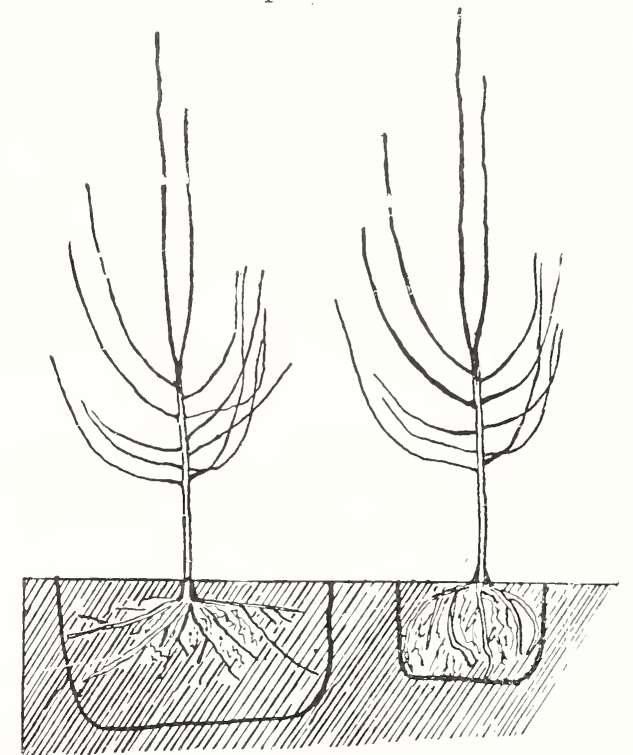

Almost Sure to Live

Almost Sure to Die

Dig holes large enough to admit roots in nat ural position. Set several inches deeper than they stood in nursery row. Pack soil solid about roots.

\section{MULCHING}

Unless thorough surface cultivation will be practiced during the summer a mulch should be applied. This may be a layer of coarse manure or vegetable matter around the trees three to six inches deep, and extending out from the trees three or five feet. Mulching protects the soil against the sun and drying winds; against alternate freezing and thawing, and provides some plant food.

\section{PRUNING}

The pruning of trees should begin when they are planted. The transplanting of a tree marks a very critical point of its life history, and to neglect careful and proper methods of planting and pruning at that time is to invite disaster or, at least, unsatisfactory returns from one's efforts.

Apple and Pear-Select from three or five of the branches to form the permanent head of the tree. These branches should be well distributed around the trunk, and at safe distance apart up and down the trunk. If two branches come out, one exactly opposite the other, forming a croteh, a split may occur at this weak point in later life, when the tree is full of fruit. Shorten these 
selected branches to about five buds, cutting the branches just above a bud that points outward. Remore all the other branches close to the trunk, leaving no stub longer than one-eighth to onequarter inch. Also shorten back two-thirds the central leader of the tree, if one exists, else the tree assumes a too upright growth for best results in later life.

Cherry-Five or six good limbs, well distributed around the trunk will be sufficient to form a well balanced top. The limbs left after pruning should not be cut back as sererely as recom. mended for some other classes.

Plum-Cut back all branches to about two or three buds. After the tree has grown for a year, remove all but four or five branches, but do not cut these back. These limbs will form the permanent framework for the top and subsequent growth may be pruned to meet the requirements or taste of the planter.

\section{SMALL FRUITS}

Gooseberries and Currants-Prepare the ground by deep plowing or spading. Cut the plants back fully one-half. Plant four feet apart both ways, same depth as plants stood in the nursery row, and firm soil well.

Blackberries, Raspberries, Dewberries-These should be set fairly deep, except one-year old raspberry plants, the new growth of which starts from the crown in the mass of hair-like roots; these should be planted shallow, with the crown not more than one inch below the surface. Too deep planting is often fatal to one-year-old rasp. berry plants. Plant in rows five or six feet apart, with plants three to four feet apart in the row. Firm the dirt around each plant. Keep surface of ground loose. Water in dry weather during growing season. Mulch in winter after the ground is frozen.

Strawberries-Plants should be set and cared for the same as tomato and cabbage plants. Plant in rows three to three and one-half feet apart

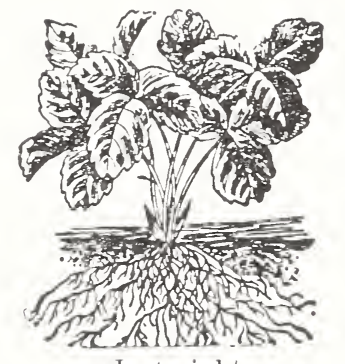

Just right

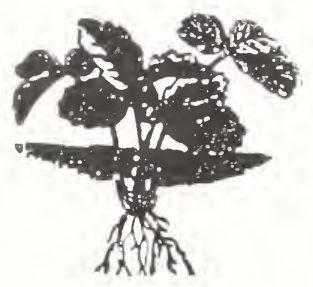

Too deep

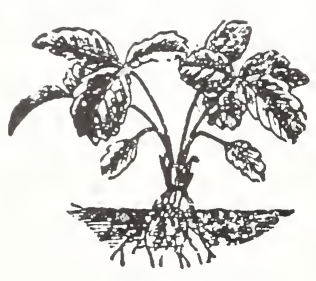

Too shallow and twelve to fifteen inches in a row. The cheapest way to grow them is to plant in long rows and tend with a corn plow, using shields. Never allow rows to spread to more than eight or ten inches in width. Cover the plants late in the fall with one or two inches of prairie hay or stable litter (if free from weed seed). This covering should be removed from the plants in early spring and left between the rows until the fruit is picked then it should be removed from the patch and the rows cultivated the same as before.

Grapes-These should be planted ten to twelve inches deep in holes large enough to admit roots without curling them, pressing soil solid about roots. Cut vines back to within three or four buds of the roots. Keep the ground clean by cultirating; if impossible to cultivate, mulch.

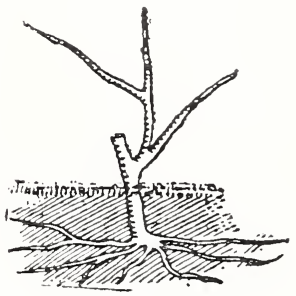

Planted too shallow.

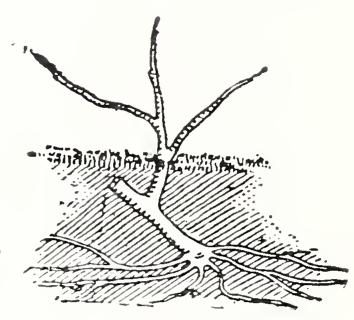

Planted just right.

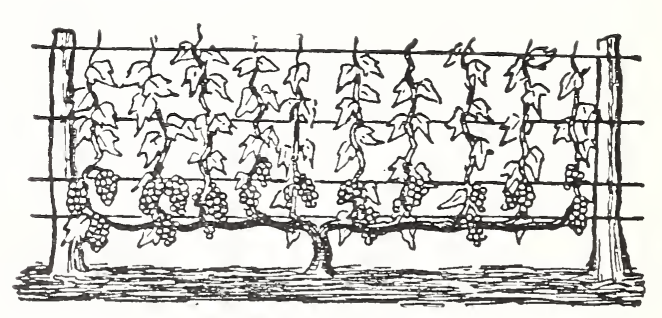

As the vine grows train to trellis as shown in illustration.

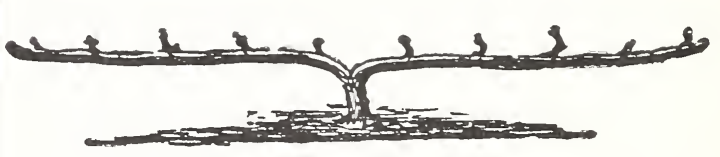

Prune in February or early March, before there are any signs of new growth. Cut back to two buds as shown. The fruit of the grape is borne only on shoots of the current year's growth, which spring from the wood of last year's growth-hence the importance of annual and intelligent pruning.

Asparagus-Prepare ground by deep plowing or spading. Set plants twelve to eighteen inches each way, three inches deep, with roots well spread out. Every fall mulch the bed well with manure.

Rhubarb-Prepare ground as for asparagus. Set the plants with crown or eye two inches under ground. Plant three feet apart each way. Mulch in winter. Give clean cultivation the same as for any other crop. 


\section{SHRUBS}

If planted in beds or groups the ground should be spaded deeply and well worked. If shrubs are set as individual specimens they should be planted the same as trees.

Set shrubs at the same depth as they stood in the nursery row, or with their crowns at about the surface of the ground. Water the plants well during the hot, dry weather and keep the ground well stirred around them. Most shrubs require judicious pruning at planting time, and subsequently. When shrubs are planted it is advisable to cut them back from one-half to twothirds with few exceptions.

\section{HEDGES}

Privet-Dig trench twelve inches deep or more and set the plants four to six inches deeper than they stood in the nursery row, or deep enough so the lower branches will be four to six inches under the ground. Such deep planting will make a compact hedge down to the ground line, but if the plants are set shallow there will always be undesirable open spaces at the base of the hedge. Some planters set Privet in a double row, eight to ten inches apart each way, which makes a very dense hedge. Cut Privet back to six inches when planting to promote thick new growth at lower part of plant.

Barberry-Spirea-Should be planted in the same manner as shrubs, either in trenches for hedge or as groups or individual specimens. Cut back and thin out one-half of top wood.

\section{ROSES}

If roses are planted in the ordinary way with the tops left exposed to the sun and drying winds of the spring, they are almost sure to

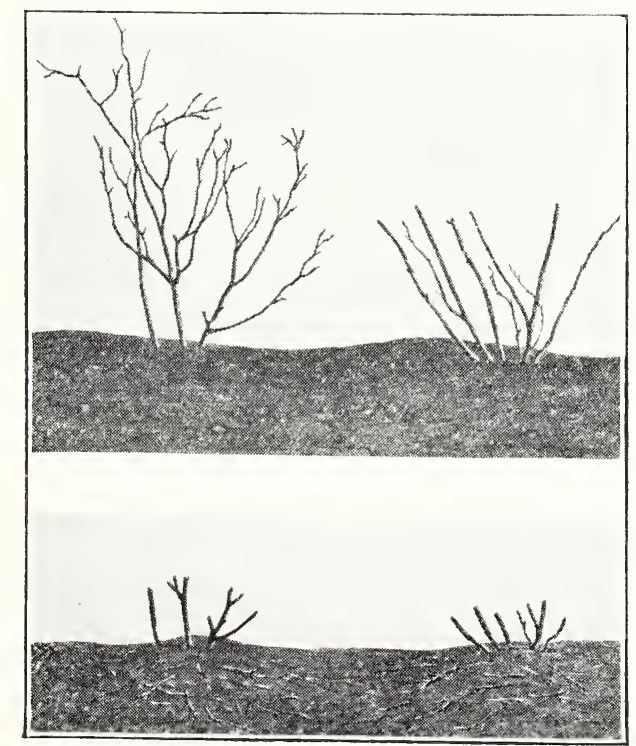

Rose Bushes Just Planted-Before and After Trimming. shrivel before time for them to grow, and thus the plants are greatly endangered, while if the following suggestions are followed, success is almost certain. The plants should be unpacked as soon as received from the nursery and planted, if possible. If unable to plant them immediately upon receiving them, they should be heeled-in deep (buried) in moist, loose earth, waiting time to plant. In planting they should be set two or three inches deeper than they stood in the nursery in well-prepared, damp soil, but not wet enough to be muddy. If the soil is dry it is well to plant the roses solidly, then wet thoroughly and after the water has soaked away, throw up a small mound of earth five or six inches high around the plant. Then cut off the branclies about one inch above the mound, leaving it this way for ten days or two weeks, or until the buds start and show a desire to grow, when the dirt mound can be raked down. Roses handled in this way hardly ever fail to make a good start and a very satisfactory growth.

\section{BULBS AND R00TS}

Prepare the ground by deep spading twelve to eighteen inches, and work it into a well pulverized condition.

Peonies-Should be set with the crown two to three inches below the surface of the ground. Plant two to two and one-half feet apart. Mulch heavily after the ground is frozen and remove mulch in the spring.

Iris-Should be set with the crown two inches below the surface. Plant twelve inches apart. Mulch as for Peonies.

Phlox-Set the crown one inch under the surface and spread out the roots. Firm well. Mulch in winter. Water in summer. Plant twelve inches apart. Gaillardia, Delphinium, Platycodon and other perennials should be planted about like Iris and Phlox.

\section{SHADE TREES}

Ornamentals-Dig holes large enough to accommodate all roots without bending or cramping. Fill the hole with good top dirt and firm it hard. When the hole is three-fourths full, allow a bucket or more of water to seep away around the roots, after which the hole may be tirely filled. It is well to mulch the tree immediately to prevent drying out. Prune all limbs back to five or seven good buds, even though the appearance of the tree is impaired by such treatment. Water trees during the sum. mer months and give them plenty of attention until they have become well established. Large sizes of shade trees can often be staked to advantage until their roots have obtained good anchorage in the soil.

\section{EVERGREENS}

These should be planted extremely solid, but be sure that all vacancies under the pronged roots are well filled with soil first, then press or tamp the soil so solid that the tree cannot be easily pulled up, leaving two inches of the soil loose to prevent baking and to take in the rain. fall. Be careful never to expose the roots to the sun and air long enough to dry them in the least, 
and if necessary to water them, it is better to dig a hole by the side of the tree one foot deep and water them through the holes. This applies to the watering of all trees. Better to water two or three pailfulls at a time in seven or eight days, as needed, than to pour water on the surface, which often does more harm than good, by crusting the surface and attracting the roots upward for moisture, instead of downward.
Mulch with old hay or chaff, throw a little soil on the mulching and it will look better and will be more effective. Evergreens should be watered during a drought in mid-summer or fall as well as spring. The ground should be filled with water at the approach of winter and then mulched. They do not need the above care after the first year. After planting protect evergreens in yard by placing a screen about each to keep dogs away.

\section{Spraying}

$\mathrm{T}$

HERE are four distinct types of troubles to combat, ie: chewing insects, sucking insects, scale insects and fungous diseases. Chewing insects are controlled with a stomach poison, some form of arsenic (lead arsenate), sucking insects, (lice or aphids) by body contact poison, (nicotine) or miscible oil (kerosene emulsion), and fungous diseases by lime-sulphur solution or Bordeaux mixture. Be sure you know what you are spraying for since arsenate of lead will not control lice or aphids, nor will nicotine or kerosene emulsion control apple worms and neither of these will have any effect on apple scab or other fungous diseases. Lime-sulphur is used as a dormant spray for scale insects and also for fungous. In spraying the apple, keep in mind the two main apple troubles in the Central West, codling moth and apple scab, and in controlling these most other troubles are incidentally controlled. Lead arsenate and lime-sulphur or Bordeaux mixture are the sprays to use.

\section{SPRAYING MATERIALS}

The most common and best form of arsenic used is "arsenate of lead." This may be secured from drug stores and seed and garden supply houses. Thoroughly dissolve three pounds of paste arsenate of lead or $1 \frac{1}{2}$ pounds of dry arsenate of lead in a small amount of water in a pail and add to fifty gallons of water or other spraying solution.

Bordeaux mixture is prepared by dissolving four pounds of copper-sulphate (bluestone), in a small amount of water and diluting to twentyfive gallons; slacking five to six pounds of good lime and adding water to make twenty-five gallons. These solutions should then be combined by pouring or dipping simultaneously from each into a third vessel or spray tank.
The commercial lime-sulphur is used almost exclusively by many fruit growers. This may be obtained from same sources as arsenate of lead or direct from manufacturers. To combine the fungus spray and the insect spray simply add the dissolved poisons to the fungus solutions.

Kerosene in its natural, undiluted state, is fatal to all insect and vegetable life, but properly prepared may be used safely and with much benefit: Dissolve a bar of Ivory soap in one gallon of hot water, then add two gallons of kerosene and churn it vigorously until cool. If made right it is then like cream, and will keep indefinitely. For general use take one part of the mixture to ten parts water and use as a spray. Will be found very valuable in getting rid of aphis, mealy bugs, red spider, etc. May be used against any soft-shelled insect.

\section{WHEN AND HOW TO SPRAY}

\section{GRAPE}

\begin{tabular}{|c|c|c|c|}
\hline What to Spray For & Treatment & When to Spray & Remarks \\
\hline $\begin{array}{l}\text { Anthracnose } \\
\text { Black Rot } \\
\text { Mildews }\end{array}$ & Bordeaux mixture & $\begin{array}{l}\text { (1) Just before buds open. } \\
\text { (2) After blossoms have fallen. } \\
\text { Two or three others at 10-14 day inter- } \\
\text { vals. }\end{array}$ & $\begin{array}{l}\text { Careful winter pruning and disposal of } \\
\text { diseased wood with application of } \\
\text { lime-sulphur (winter strength) in } \\
\text { dormant season aids in anthracnose } \\
\text { control. }\end{array}$ \\
\hline $\begin{array}{l}\text { Berry Moth } \\
\text { Leaf Hopper }\end{array}$ & $\begin{array}{l}\text { Bordeaux with } 2 \mathrm{lbs} \text {. } \\
\text { Arsenate of Lead. }\end{array}$ & $\begin{array}{l}\text { Follow program recommended above } \\
\text { when these insects are prevalent. }\end{array}$ & $\begin{array}{l}\text { Dusting with fine sulphur is recom- } \\
\text { mended for some vines of European } \\
\text { origin for mildew control. }\end{array}$ \\
\hline
\end{tabular}

BLACKBERRY, RASPBERRY AND DEWBERRY

\begin{tabular}{|c|c|c|c|}
\hline Anthracnose & $\begin{array}{l}\text { Lime-Sulphur as di- } \\
\text { rected. }\end{array}$ & $\begin{array}{l}\text { (1) In spring before growth starts }\left(2 \frac{1}{2}\right. \\
\text { gal. in } 50) \text {. } \\
\text { (2) When new shoots are } 6-8 \text { inches high } \\
(11 / 4 \text { gal. in } 50) \text {. } \\
\text { (3) Just before blooming period. Dilute } \\
\text { as in (2). }\end{array}$ & \\
\hline \multicolumn{4}{|c|}{ CURRANT AND GOOSEBERRY } \\
\hline $\begin{array}{l}\text { Leaf Spot } \\
\text { Anthracnose }\end{array}$ & Bordeaux & $\begin{array}{l}\text { Beginning as soon as the leaves are op- } \\
\text { ened make five to seven applications } \\
\text { at two-week intervals. }\end{array}$ & \\
\hline Currant Worm & $\begin{array}{l}\text { Arsenate of Lead, } 2 \\
\text { lbs. to } 50 \text { gals. } \\
\text { water. }\end{array}$ & $\begin{array}{l}\text { At the first appearance of the worms. If } \\
\text { there are two broods repeat spray. }\end{array}$ & $\begin{array}{l}\text { Dry hellebore may be dusted on, if } \\
\text { near picking time. }\end{array}$ \\
\hline $\begin{array}{l}\text { Currant Plant } \\
\text { Louse }\end{array}$ & $\begin{array}{l}\text { Nicotine sulphate, } 1 \\
\text { to } 800 \text { of water. }\end{array}$ & $\begin{array}{l}\text { Soon after eggs hatch in spring (soon } \\
\text { after the leaves open). }\end{array}$ & $\begin{array}{l}\text { Thoroughness necessary, hitting all } \\
\text { leaves from beneath. }\end{array}$ \\
\hline
\end{tabular}




\section{STRAWBERRY}

\begin{tabular}{l|l|l|l}
\hline What to Spray for & Treatment & When to Spray & \multicolumn{1}{c}{ Remarks } \\
\cline { 2 - 2 } & Bordeaux & $\begin{array}{l}\text { Before blossoms open. Additional appli- } \\
\text { cations if spot appears. }\end{array}$ & $\begin{array}{c}\text { Renew beds frequently. May mow off } \\
\text { and burn foliage after berries are } \\
\text { picked. }\end{array}$ \\
\hline
\end{tabular}

APPLE

\begin{tabular}{|c|c|c|c|}
\hline Scale Insects & $\begin{array}{l}\text { Lime-Sulphur, } 1 \text { to } 8 ; \\
\text { Scalecide. } \\
\text { Miscible Oils }\end{array}$ & $\begin{array}{l}\text { In dormant season; when trees are leaf- } \\
\text { less. }\end{array}$ & $\begin{array}{l}\text { Protect men and animals at work from } \\
\text { caustic action of Linie-sulplıur on } \\
\text { the skin. }\end{array}$ \\
\hline $\begin{array}{l}\text { Apple Aphids } \\
\text { (lice) }\end{array}$ & $\begin{array}{l}\text { Nicotine, } 1 \text { to } 800, \\
\text { added to lime-sul- } \\
\text { phur, } 1 \text { to } 40 .\end{array}$ & $\begin{array}{l}\text { In spring when buds are bursting show- } \\
\text { ing green tips. }\end{array}$ & $\begin{array}{l}\text { Of no use after leaves are curlecl. Use } \\
\text { high pressure. }\end{array}$ \\
\hline $\begin{array}{l}\text { Scab } \\
\text { Black Rot } \\
\text { Bud Moth } \\
\text { Cankerworm } \\
\text { Tent Caterpillar }\end{array}$ & $\begin{array}{l}\text { Lime-Sulphur, } 1 \text { to } \\
40 \text {, with } 2 \text { lbs. Ar- } \\
\text { senate of Lead. }\end{array}$ & $\begin{array}{l}\text { When flower buds show pink, but be- } \\
\text { fore any have opened. (Other sprays } \\
\text { as recommended for codling moth, be- } \\
\text { low, will incidentally control troubles } \\
\text { in this group.) }\end{array}$ & $\begin{array}{l}\text { In severe cases of cankerworm use } \\
\text { Paris Green } 4 \text { oz. in fifty gallons of } \\
\text { water with twice as nuch slaked } \\
\text { lime. }\end{array}$ \\
\hline Codling Moth & $\begin{array}{l}\text { Lime-Sulphur, } 1 \text { to } \\
40 \text {, with } 2 \text { lbs. Ar- } \\
\text { senate of Lead. } \\
\text { Arsenate of Lead, } 2 \\
\text { lbs. to } 50 \text { gals. } \\
\text { water. }\end{array}$ & $\begin{array}{l}\text { (1) When most of the petals have fallen } \\
\text { (calyx spray). } \\
\text { (2) Approximately three weeks after the } \\
\text { bloom. } \\
\text { (3) Approximately ten weeks after the } \\
\text { bloom. } \\
\text { (4) Fifteen to seventeen weeks after the } \\
\text { bloom. }\end{array}$ & $\begin{array}{l}\text { After weather becomes hot (from allout } \\
\text { July 1) discontinue lime-sulplum and } \\
\text { use Bordeaux with } 2 \text { lbs. Arsenate } \\
\text { of Lead. } \\
\text { Necessary in South where there may be } \\
\text { three broods in one season. }\end{array}$ \\
\hline \multirow[t]{2}{*}{$\begin{array}{l}\text { Blotch } \\
\text { Curculio }\end{array}$} & $\begin{array}{l}\text { Lime-Sulphur, } 1 \text { to } \\
40 \text {, with } 2 \text { lbs. Ar- } \\
\text { senate of Lead. }\end{array}$ & $\begin{array}{l}\text { (1) As in (2) under codling moth } \\
\text { (above) except two weeks after bloom } \\
\text { in south. }\end{array}$ & $\begin{array}{l}\text { Clean orcharding assists in eurculio } \\
\text { control. Spraying not always wholly } \\
\text { effective. }\end{array}$ \\
\hline & $\begin{array}{l}\text { Bordeaux, } 4-4-50 \text {, } \\
\text { with } 2 \text { lbs. Arsenate } \\
\text { of Lead. }\end{array}$ & $\begin{array}{l}\text { (2) Approximately five weeks after the } \\
\text { fall of the bloom. } \\
\text { (3) As in (3) under codling moth } \\
\text { (above) }\end{array}$ & $\begin{array}{l}\text { Arsenate of Lead may be omitted if no } \\
\text { curculio is present. }\end{array}$ \\
\hline $\begin{array}{l}\text { Sooty Blotch } \\
\text { Fly Speck }\end{array}$ & & $\begin{array}{l}\text { Usually checked as incidental results of } \\
\text { applications recommended above. }\end{array}$ & $\begin{array}{l}\text { More common in regions where air and } \\
\text { water drainage is poor. }\end{array}$ \\
\hline Bitter Rot & Bordeaux & $\begin{array}{l}\text { Where disease is looked for begin spray- } \\
\text { ing in early summer, making applica- } \\
\text { tions often enough to keep fruit coated. }\end{array}$ & \\
\hline $\begin{array}{l}\text { Apple Rust or } \\
\text { Cedar Rust }\end{array}$ & Spraying not effective & Remove cedar trees nearby. & $\begin{array}{l}\text { The rust cannot live without cedars on } \\
\text { which it spends part of the year. }\end{array}$ \\
\hline Blight & & nder Pear, Fire Blight. & \\
\hline
\end{tabular}

PEACH AND PLUM

\begin{tabular}{l|l|l|l}
\hline $\begin{array}{l}\text { San Jose Scale } \\
\text { European Fruit } \\
\text { Scale }\end{array}$ & Lime-Sulphur, 1 to 8 & When tree is dormant. & \\
$\begin{array}{llll}\text { Curculio } \\
\begin{array}{l}\text { Brown Rot } \\
\text { Leaf Spot }\end{array}\end{array}$ & $\begin{array}{c}\text { Lime-Sulphur, 1 to } \\
50, \text { with 2 lbs. Ar- } \\
\text { senate of Lead. }\end{array}$ & Similar to cherry, which see. & $\begin{array}{c}\text { Brown rot spreads very rapiclly in } \\
\text { warm, moist weather and ean le con- } \\
\text { trolled only if fruit is kcpt coated. }\end{array}$ \\
\hline
\end{tabular}

PEAR

\begin{tabular}{l|l|c|c|c|}
\hline \hline Fire Blight & Spraying ineffective & $\begin{array}{c}\text { In some cases where particular care is taken, prompt and severe pruning at the } \\
\text { first sign of blight, disinfecting tools and wounds with corrosive sul,limate } \\
\text { solution, may check its spread to some extent. }\end{array}$ \\
$\begin{array}{l}\text { Scale Insects } \\
\begin{array}{l}\text { Blister Mite } \\
\text { Pear Psylla }\end{array}\end{array}$ & $\begin{array}{l}\text { Lime-Sulphur, 1 to 8; } \\
\text { Scalecide. } \\
\text { Miscible Oils. }\end{array}$ & In dormant season, preferably early spring & $\begin{array}{c}\text { Scrape dormant trees and burn all orch- } \\
\text { ard trash to aid in psylla control. }\end{array}$ \\
$\begin{array}{l}\text { Practically all the other common diseases and insects on the apple are also found on the pear to some extent. See inethods } \\
\text { of control under apple (above). }\end{array}$
\end{tabular}

\section{CHERRY}

\begin{tabular}{|c|c|c|c|}
\hline $\begin{array}{l}\text { Curculio } \\
\text { Brown Rot } \\
\text { Leaf Spot } \\
\text { Shot Hole Fungus }\end{array}$ & $\begin{array}{l}\text { Lime-Sulphur, } 1 \text { to } \\
50 \text {, with } 2 \text { lbs. Ar- } \\
\text { senate of Lead. }\end{array}$ & $\begin{array}{l}\text { (1) Just before buds open. } \\
\text { (2) Immediately after blossoms fall. } \\
\text { (3) About ten days after (2). } \\
\text { (4) Additional sprays if necessary at } \\
\text { two-week intervals. }\end{array}$ & $\begin{array}{l}\text { In some localities it may be safer to } \\
\text { dilute the lime-sulphur somewhat } \\
\text { preventing foliage injury. }\end{array}$ \\
\hline Cherry Aphis & $\begin{array}{l}\text { Nicotine sulphate, } 1 \\
830 .\end{array}$ & $\begin{array}{l}\text { When aphids first appear before they } \\
\text { have caused the leaves to curl. }\end{array}$ & $\begin{array}{l}\text { Be careful to cover underside of leaves } \\
\text { Use high pressure and soap. }\end{array}$ \\
\hline Cherry Slug & $\begin{array}{l}\text { Arsenate of Lead, } 2 \\
\text { lbs. to } 50 \text { gals. } \\
\text { water. }\end{array}$ & On first appearance of insects. & \\
\hline
\end{tabular}

ROSES, FLOWERS AND VINE PLANTS

\begin{tabular}{c|c|c|c}
\hline \hline $\begin{array}{c}\text { Slugs (small green } \\
\text { worms on under } \\
\text { side of roseleaves) } \\
\text { Aphids (plant lice) }\end{array}$ & $\begin{array}{c}3 / 4 \text { pint "Black Leaf } \\
40 . " 4 \text { lbs. soap in } \\
100 \text { gals. water. }\end{array}$ & Spring and Summer & $\begin{array}{c}\text { Spray whole plant thoroughly, es- } \\
\text { pecially under side of leaves. }\end{array}$ \\
\hline
\end{tabular}

SHADE TREES

\begin{tabular}{l|l|l|l|}
\hline $\begin{array}{l}\text { Caterpillars } \\
\text { Measuring Worms } \\
\text { Canker Worms }\end{array}$ & $\begin{array}{l}\text { lbs. Arsenate of } \\
\text { Lead to 97 gals. } \\
\text { water. }\end{array}$ & Spring and Summer & \\
\hline
\end{tabular}




\section{Table of Contents}

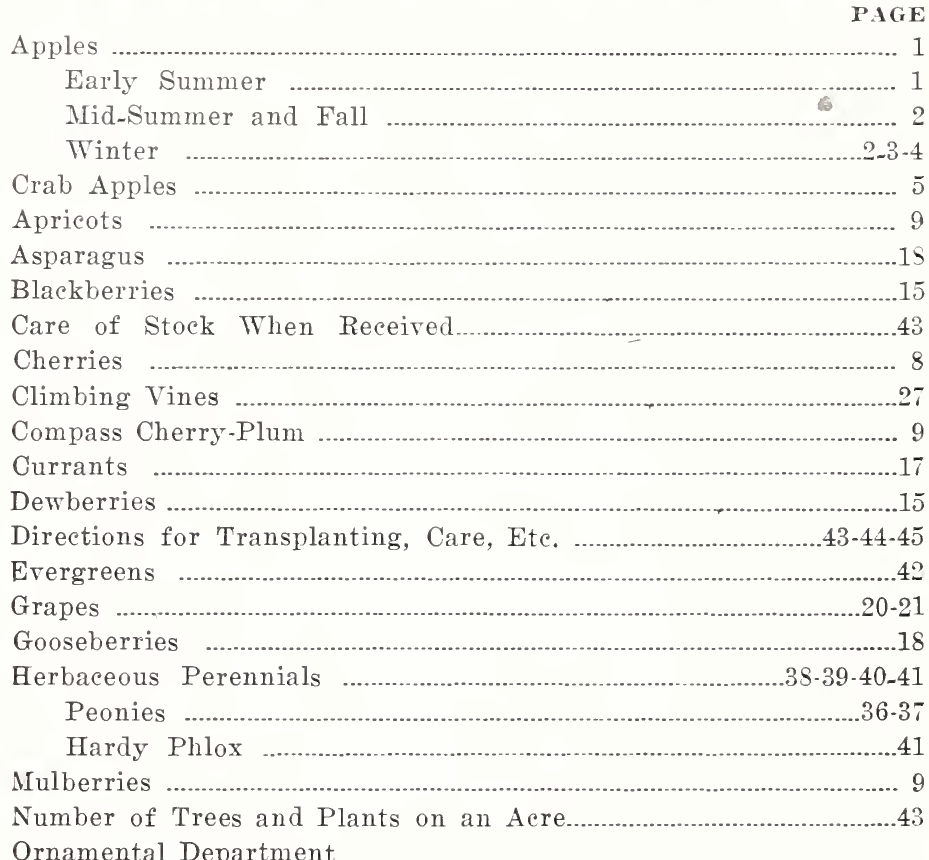

Deciduous Trees ....................................................................33-34-35

Weeping Trees ...........................................................................................35

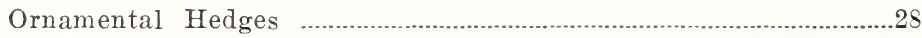

Ornamental Shrubs .........................................................22_-23-24-25-26

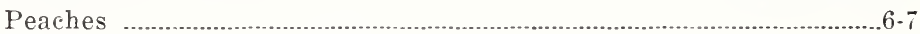

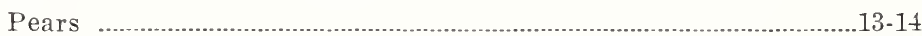

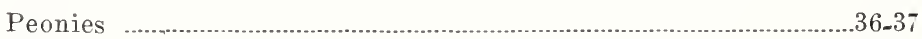

Planting, Pruning …........................................................43-44-45

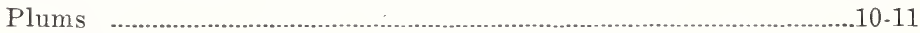

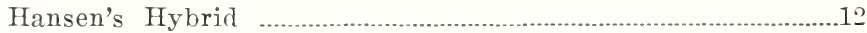

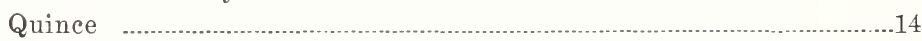

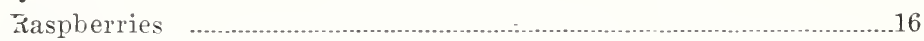

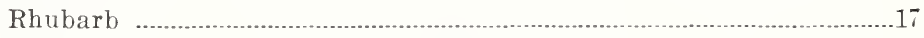

Roses, Everblooming Hybrid Teas ….............................................30

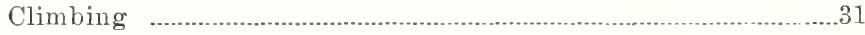

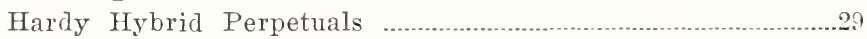

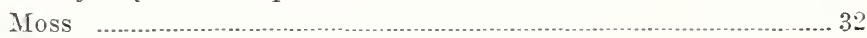

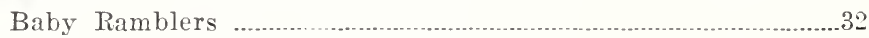

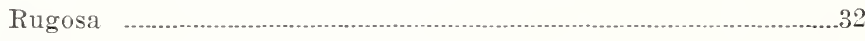

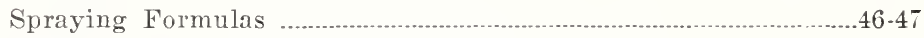

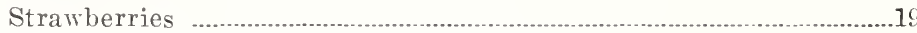




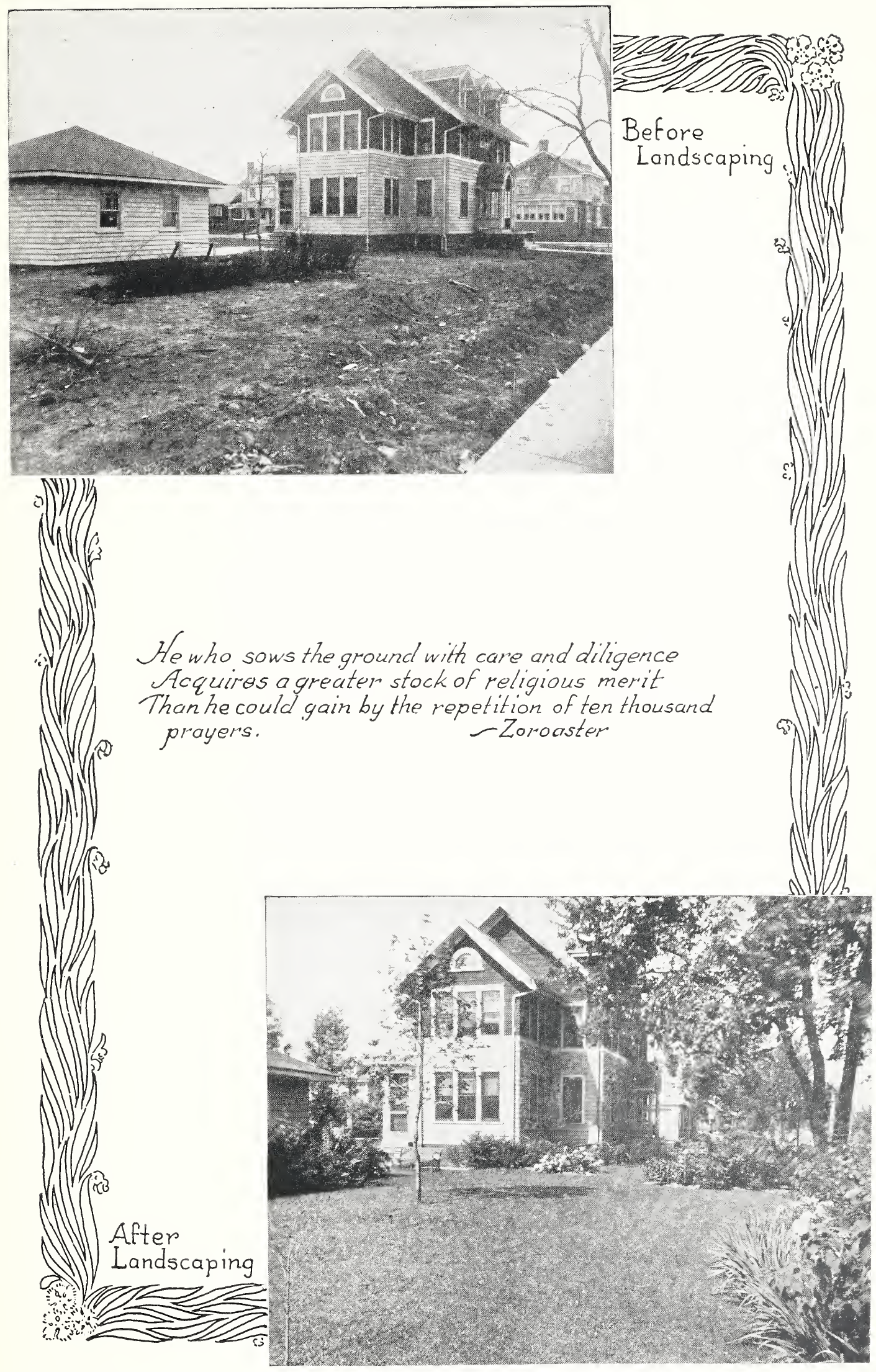


Like a lane into heaven

That leads from a dream

- Lanier

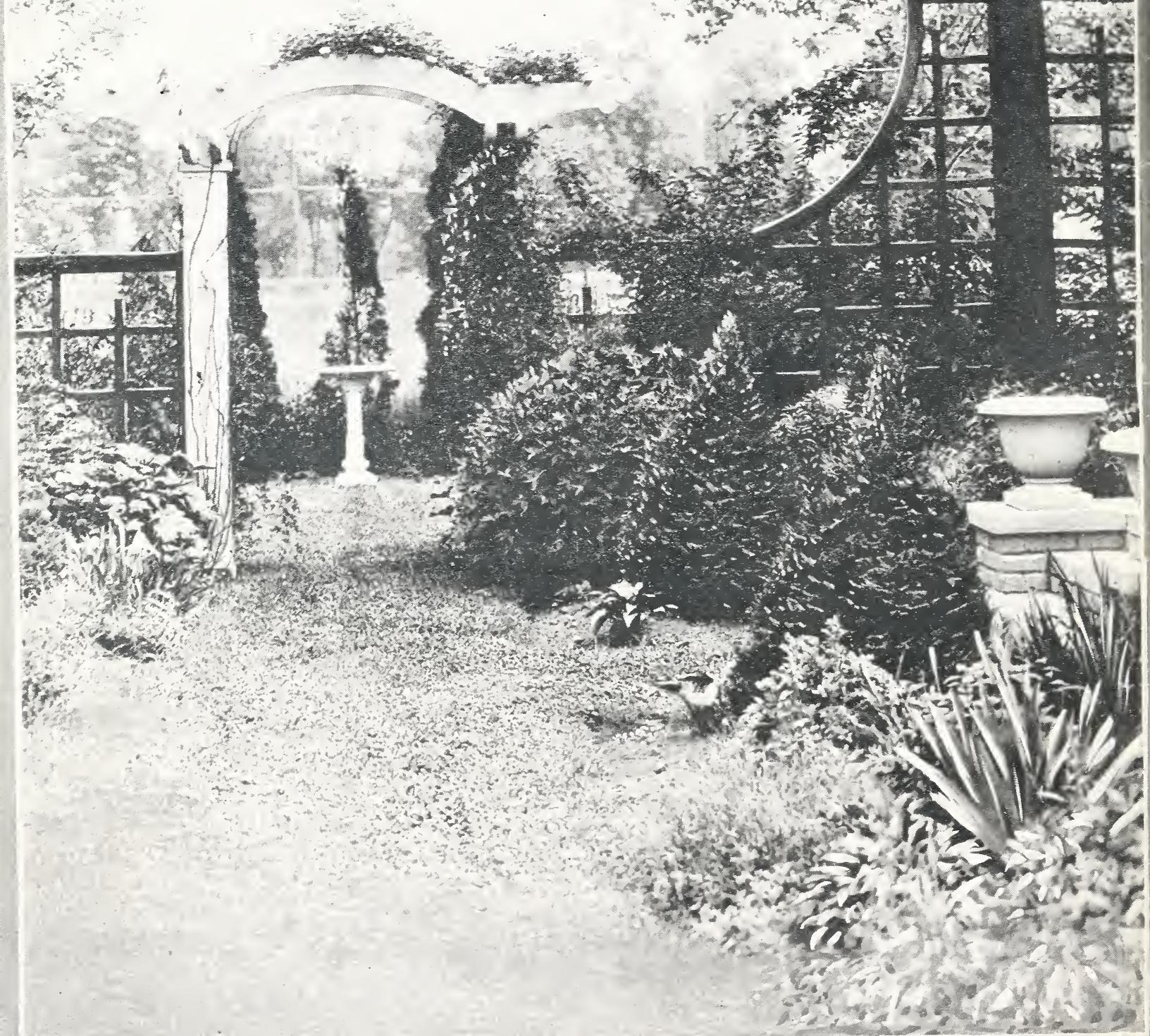

